$$
\text { UNIVERSIDADE DE SÃO PAULO }
$$

FACULDADE DE FILOSOFIA, LETRAS E CIÊNCIAS HUMANAS DEPARTAMENTO DE LETRAS CLÁSSICAS E VERNÁCULAS PROGRAMA DE PÓS-GRADUAÇÃO EM FILOLOGIA E LÍNGUA PORTUGUESA

PEDRO DA SILVA DE MELO

CAROLINA MARIA DE JESUS E A PAIXÃO PELA ESCRITA:

UM ESTUDO SOCIOLINGUÍSTICO DE QUARTO DE DESPEJO (VERSÃO CORRIGIDA) 


\title{
CAROLINA MARIA DE JESUS E A PAIXÃO PELA ESCRITA: \\ UM ESTUDO SOCIOLINGUÍSTICO DE QUARTO DE DESPEJO (VERSÃO CORRIGIDA)
}

\begin{abstract}
Dissertação apresentada ao Programa de Pós-Graduação em Filologia e Língua Portuguesa do Departamento de Letras Clássicas e Vernáculas da Faculdade de Filosofia, Letras e Ciências Humanas da Universidade de São Paulo, para a obtenção do título de Mestre em Filologia e Língua Portuguesa.
\end{abstract}

Orientador: Prof. Dr. Hudinilson Urbano

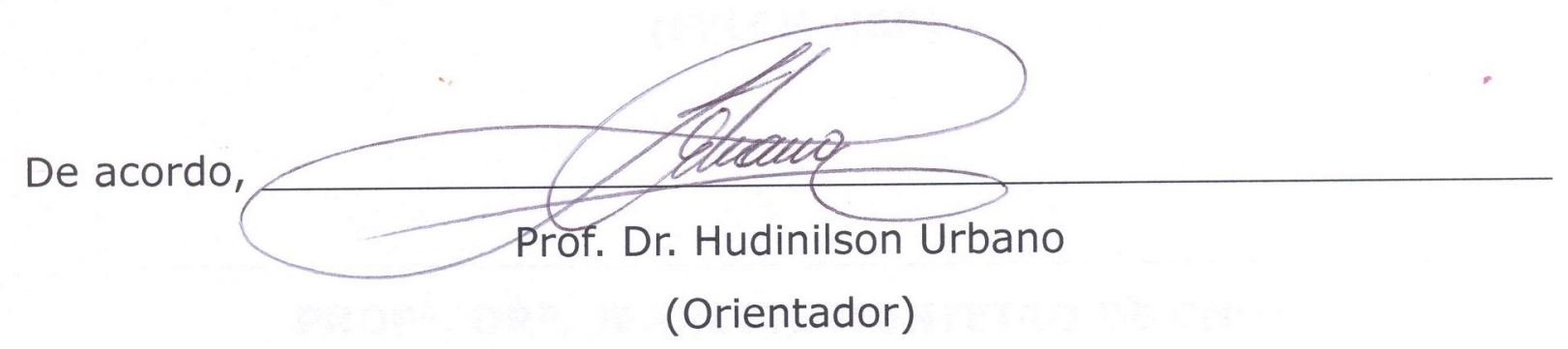

São Paulo 


\section{CAROLINA MARIA DE JESUS E A PAIXÃo PELA ESCRITA: UM ESTUDO SOCIOLINGUÍSTICO DE QUARTO DE DESPEJO}

Dissertação de Mestrado apresentada ao Programa de Pós-Graduação em Filologia e Língua Portuguesa do Departamento de Letras Clássicas e Vernáculas da Faculdade de Filosofia, Letras e Ciências Humanas da Universidade de São Paulo

BANCA EXAMINADORA

PROF. DR. HUDINILSON URBANO

(FFLCH-USP - PRESIDENTE)

PROFa. DRa. ELIS DE ALMEIDA CARDOSO CARETTA (FFLCH-USP)

PROFa. DRa. JEANETTE MONTEIRO DE CNOP (UEM-PR) 


\section{DEDICATÓRIA}

À minha mãe, Azenete, in memoriam

Ao meu pai, Pedro de Melo, cujos esforços, quase sobre-humanos, deram este fruto temporão

Ao Prof. Dr. Hudinilson Urbano, pela generosidade

À Carolina Maria de Jesus, in memoriam. Sua história de vida é um exemplo de esforço e de amor

À Profa Dra Therezinha de Lourdes Coelho Zilli

À Profa Dra Elis de Almeida Cardoso e à Profa Dra Maria Lúcia da Cunha Victório de Oliveira Andrade

À Valdineia, pela compreensão... por ter suportado tantas horas de omissão por causa da minha pesquisa

À Maísa Silveira Martins

Aos meus amigos Antônio Augusto de Assis, Divenei Boseli, Eliana Ruiz Jimenez, Giva da Rocha, Renato Alves e Sérgio Ferreira da Silva

À Marina Bruna, in memoriam

Ao Rubens Jorge, "Rubão", in memoriam 


\section{AGRADECIMENTOS}

Em primeiro lugar, quero agradecer ao meu Orientador, Prof. Dr. Hudinilson Urbano, pois sem a sua acolhida generosa este trabalho não se realizaria. Ser seu orientando é uma grande honra! Sou-Ihe infinitamente grato pela orientação firme e primorosa, pelos caminhos apontados, pela paixão em ensinar, pela disposição, pela quase inacreditável paciência...

Não poderia me furtar a agradecer aos meus pais, Pedro e Azenete, pelo apoio total e irrestrito, com sacrifícios típicos de uma família pobre para que eu pudesse chegar onde a Vida não Ihes permitiu chegar. Minha mãe, infelizmente, não chegou até aqui, mas seu apoio foi imprescindível. Com todo o afeto do mundo... seu sacrifício, meu pai e minha mãe, valeu a pena!

Não poderia deixar de expressar meus agradecimentos à Vera Eunice de Jesus Lima, filha e guardiã da memória de Carolina. Sua amizade é um privilégio. As entrevistas concedidas foram de grande valia para traçar o perfil de Carolina.

À Maísa Silveira Martins, minha doce amiga, companheira das águas turbulentas da graduação que sempre me incentivou a nunca desistir. Maísa me ensinou inglês, me incentivou a continuar, me deu o braço generoso da sua amizade.

À Profa Dra Therezinha de Lourdes Coelho Zilli, minha querida professora de Literatura Portuguesa da graduação, a primeira professora que acreditou em mim, que me incentivou a continuar os estudos, a me tornar um pesquisador... Demorei, professora, mas aqui estou. A senhora sempre acreditou em mim, mesmo quando eu não acreditava...

À Profa Dra Elis de Almeida Cardoso e à Profa Dra Maria Lúcia da Cunha Victório de Oliveira Andrade, importantes no meu percurso acadêmico, não só pelos cursos na Pós-Graduação, mas também pelos 
caminhos apontados para o aprimoramento deste trabalho no Exame de Qualificação.

Ao Agnaldo Holanda Lopes, colega uspiano que também tem o privilégio de ser orientando do Professor Urbano. Pelo apoio em horas de dificuldade, pelo incentivo, pela mão estendida e, acima de tudo, pelas excelentes críticas ao meu trabalho. Amigo não é quem elogia o tempo todo, mas quem nos mostra em que devemos melhorar.

Enfim, a todos os meus amigos que não posso mencionar aqui porque o espaço é curto e a memória, mais curta ainda, poderia ser injusta. A todos vocês, porque iluminaram minha trajetória. 


\section{RESUMO}

Esta dissertação tem dois objetivos básicos: primeiro, investigar se há marcas de oralidade na linguagem narrativa e das personagens do livro "Quarto de despejo: diário de uma favelada", de Carolina Maria de Jesus (1914-1977); segundo, examinar como essas manifestações se processam linguisticamente no texto no plano lexical. Suscitam-se, portanto, duas perguntas: Primeira: Há em Quarto de despejo manifestações linguísticas da oralidade? Segunda: Em caso afirmativo, em que níveis essa oralidade se processa linguisticamente? Para responder a essas perguntas, temos a hipótese de que a língua falada foi aproveitada de maneira mais ou menos inconsciente pela autora de Quarto de despejo e que, entre vários níveis linguísticos, a oralidade se manifesta de maneira notável em nível lexical, por meio de um vocabulário de uso popular. Estudar-se-á como o léxico da linguagem narrativa e das personagens apresenta efeitos de língua falada, tornando o texto dinâmico e expressivo. Este trabalho está teoricamente fundamentado em pressupostos da Sociolinguística e da Estilística. A metodologia de trabalho envolveu várias leituras da obra, anotações de vocabulário e análises à luz da teoria proposta. Estabelecem-se relações entre fala e escrita, compreendidas não como uma dicotomia, mas como polos de um continuum tipológico. Nesse continuum, um gênero da escrita pode apresentar características da fala e vice-versa. Ressalte-se que, tendo em vista esse referencial teórico, a narrativa de Quarto de despejo não é considerada um texto oral, mas um texto escrito em cuja enunciação se evidencia a presença da oralidade graças a um leque de vocábulos expressivos.

Palavras-chave: Língua Falada; Língua Escrita; Níveis de registro; variedade culta; variedade popular; expressividade; Quarto de despejo; Carolina Maria de Jesus 


\section{ABSTRACT}

This thesis has two basic goals: first, to investigate whether there are marks of orality in the narrative language and lines from the characters from the book "Child of the dark: The diary of Carolina Maria de Jesus", by Carolina Maria de Jesus (1914-1977); secondly, to examine how these manifestations are processed linguistically into the text on the lexical sphere. Two questions, therefore, are raised: First: are there linguistic manifestations of orality in "Child of the dark"? Second: if so, at what levels is this orality processed linguistically? To answer those questions, we hypothesized that the spoken language was used more or less unconsciously by the author of Child of the dark, and that between several linguistic levels, orality manifests itself in a remarkable manner in the lexical level, by use of a colloquial vocabulary. We shall study how the lexicon of the narrative language and of the characters has effects of the spoken language, making the text dynamic and expressive. This paper is theoretically grounded in assumptions of Sociolinguistic and Stylistic. The work methodology involved several readings of the book, vocabulary annotations and analysis in the light of the proposed theory. Relationships between speech and writing are set, understood not as a dichotomy but as poles of a typological continuum. In this continuum, a genre of writing can display characteristics of speech and vice versa. It is emphasized that, in view of that theoretical framework, the narrative of Child of the dark is not regarded as an oral text, but as a written text where enunciation highlights the presence of orality using a variety of expressive vocabularies.

Keywords: Spoken Language; Written Language; registry levels; standard variety; colloquial variety; Expressivity; Child of the dark; Carolina Maria de Jesus 


\section{SUMÁRIO}

Página

LISTA DE TABELAS

INTRODUÇÃO

0.1 - Um olhar sobre Quarto de despejo: proposta de um estudo sociolinguístico

0.2 - A estrutura da dissertação

0.3 - Percurso metodológico

CAPÍt ULO 1. QUARTO DE DESPEJO: A AUTORA E SUA OBRA 26

1.1 - A saga da "Cinderela negra"

1.2 - Quarto de despejo: as faces da narrativa de Carolina

1.3 - Carolina Maria de Jesus e o português popular escrito de Quarto de despejo: panorama linguístico da obra

1.3.1 - Rotacismos

1.3.2 - A substituição de "e" por "i"

1.3.3 - A substituição de "o" por "u"

1.3.4 - Ditongação em monossílabos tônicos

1.3.5 - Substituições resultantes da indecisão de como representar um determinado fonema

1.3.6 - Formas verbais

1.3.7 - A concordância

CAPÍTULO 2 - ESTRUTURA DA NARRATIVA

2.1 - Foco narrativo: o ponto de vista do narrador

2.2 - Os personagens

2.3 - Tempo e Espaço

2.4 - Conflito

2.5 - O discurso direto, indireto e indireto-livre: a representação das vozes no discurso

2.5.1 - O discurso direto

2.5.2 - O discurso indireto

65

2.5.3 - O discurso indireto-livre

66

2.6 - Alinhavando as ideias 
3.1.1 - A lexia simples $\quad 71$

$\begin{array}{ll}3.1 .2 \text { - A lexia composta } & 71\end{array}$

3.1.3 - A lexia complexa estável 71

3.1.4 - A lexia textual $\quad 72$

3.2 - Palavras lexicais e palavras gramaticais $\quad 73$

3.3 - Campos semânticos $\quad 74$

3.4 - A dimensão expressiva do léxico 78

CAPÍTULO 4 - DISCUTINDO AS RELAÇÕES ENTRE LÍNGUA FALADA E LÍNGUA ESCRITA 79

4.1 - A variação linguística: entre a norma e a mudança $\quad 79$

4.1.2 - A variação diatópica $\quad 81$

4.1.3 - A variação social ou diastrática $\quad 82$

4.1.5 - A variação estilística ou diafásica 83

4.1.6 - Estabelecendo ligações: os níveis de linguagem 84

4.2 - Modalidades linguísticas: o continuum fala/escrita 87

4.3 - A representação da Oralidade no texto literário: 95

4.4 - O dicionário como ferramenta para o estudo do vocabulário de uso oral 97

4.5 - Traços da oralidade no plano lexical: características do vocabulário popular 100

4.5.1 - A linguagem informal: um vocabulário referente à pobreza e ao quotidiano do povo 100

4.5.2 - A gíria como elemento expressivo da linguagem popular 102

4.5.3 - Desenfoque semântico: imprecisão, generalização e deturpação de sentido 105

4.5.4 - Metáforas e comparações concretas 108

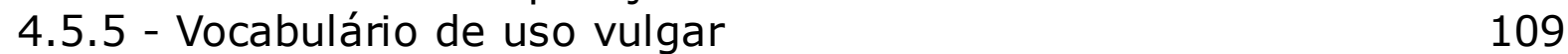

4.5.6 - Vocabulário de uso injurioso 112

4.5.7 - Vocabulário de uso afetivo: os hipocorísticos e os apelidos 113

TERCEIRA PARTE - ANÁLISE DO CORPUS 116

\section{CAPÍTULO 5 - USOS VOCABULARES DE QUARTO DE DESPEJO 117}

5.1 - Traços orais do léxico de Quarto de despejo 122

5.1.1 - Vocábulos de uso informal: a caracterização do quotidiano das pessoas do povo

122

5.1.2 - A gíria como uma das representações da língua falada em Quarto de despejo

5.1.3 - A imprecisão de sentido: vocábulos desfocados 133

5.1.4 - A presença da linguagem de uso vulgar em Quarto de despejo135

5.1.5 - A linguagem injuriosa dos moradores da favela 143

5.1.6 - O uso de hipocorísticos e apelidos $\quad 145$

5.2 - A expressividade de um léxico em permanente colisão 148

5.2.1 - Os campos semânticos de Quarto de despejo 149

$\begin{array}{ll}\text { 5.2.1.1 - A pobreza } & 148\end{array}$ 
5.2.1.2 - A favela

152

5.3 - Vocábulos de feição culta ou preciosa na linguagem narrativa de Quarto de despejo

CONCLUSÃO

159

APÊNDICE: Glossário

163

REFERÊNCIAS BIBLIOGRÁFICAS 
Tabela 01 - Organização de Quarto de despejo 29

Tabela 02 - Concepções de léxico $\quad 69$

Tabela 03 - Modelo de campo semântico $\quad 75$

Tabela 04 - Confluência entre Modalidades e Níveis de registro 91

Tabela 05 - Língua Falada (LF) 95

Tabela 06 - Língua Escrita (LE) 95

Tabela 07 - Quarto de Despejo - Lexias de traço popular 118

Tabela 08 - Quarto de despejo - Lexias de traço culto 120

Tabela 09 - Meu Estranho Diário - Lexias de traço popular 121

Tabela 10 - Meu Estranho Diário - Lexias de traço culto 121 


\section{INTRODUÇÃO}

Durante muito tempo, os estudos da linguagem foram pautados pela língua escrita literária, tradicionalmente considerada superior à língua falada e "único" modelo digno de ser chamado de "língua".

Com o advento da tecnologia e a possibilidade de gravação e constituição de corpora de língua falada, estudos fundamentados na Sociolinguística, na Pragmática e na Análise da Conversação passaram a demonstrar a influência ou presença da língua falada na escrita, possibilitando, inclusive, a análise de textos escritos anteriores ao surgimento da gravação em áudio e/ou vídeo.

Parte-se da premissa de que, em determinados estágios, a língua escrita não foi absolutamente impermeável aos influxos da oralidade, de modo especialmente notável em textos literários, quer dialogados quer não.

Desse modo, fenômenos sistemáticos da língua falada são observáveis em determinados textos escritos, independentemente do gênero a que pertençam. Isso implica o conceito de marcas, efeitos, traços ou manifestações da língua falada na língua escrita, muito frequentes em textos literários (poemas, contos, crônicas, romances, relatos autobiográficos e diálogos teatrais). Naturalmente tais marcas não aparecem apenas em textos literários e se fazem notar em textos jornalísticos, publicitários, histórias em quadrinhos (HQ), entre outros.

Os estudos linguísticos demonstram a obsolescência da visão tradicional de língua escrita como superior à língua falada. Não se pode fazer juízo de valor sobre nenhuma das duas, visto que ambas são formas legítimas de expressão de qualquer comunidade linguística e possuem suas especificidades.

Pesquisas recentes sobre essas modalidades, ainda que reconheçam a dicotomia sonora e gráfica, têm revelado, para além dessa realidade 
dicotômica, um contínuo tipológico entre ambas, na medida em que outras variáveis entram em jogo.

Sob essa perspectiva, então, fala e escrita constituem um contínuo, abstração feita à sua produção sonora ou gráfica. Tais modalidades específicas se entrecruzam em determinadas condições de produção.

Koch, ao elencar características típicas que contrapõem o texto falado ao texto escrito, ressalta que tais aspectos

\begin{abstract}
nem sempre distinguem as duas modalidades, mesmo porque existe uma escrita informal que se aproxima da fala e uma fala formal que se aproxima da escrita, dependendo da situação comunicativa. Assim, o que se pode dizer é que a escrita formal e a fala informal constituem os polos oposto de um contínuo, ao longo do qual se situam os diversos tipos de interação verbal. $(\mathrm{KOCH}, 2007$, p. 78)
\end{abstract}

Não se trata, portanto, de negar ou relativizar as distinções entre texto falado e texto escrito, mas de reconhecer que há pontos de convergência entre ambos.

Julgamos que isso se manifesta de modo notável na prosa memorialística de Carolina Maria de Jesus, cujo livro de estreia, Quarto de despejo: diário de uma favelada, é corpus desta dissertação. Embora não seja um texto oral, mas escrito, no sentido de produção gráfica, possui nítidas marcas da influência da língua falada.

0.1 - Um olhar sobre Quarto de despejo: proposta de um estudo sociolinguístico

Carolina Maria de Jesus já foi chamada de "escritora improvável". "Improvável" por ser negra, neta de escravos, nascida sob o estigma da miserabilidade, mas, sobretudo, por haver estudado apenas os dois primeiros anos do Ensino Fundamental e passado a vida inteira lutando quase inutilmente contra a miséria e o preconceito racial. Esses fatores de exclusão social a tornariam somente mais uma entre uma multidão anônima de negros pobres e discriminados, não fora um detalhe com que 
se sobressaiu como uma mulher sui generis: a prática social da escrita e o apego quase maníaco pela literatura.

Seria apenas mais uma entre tantas indefinidas pessoas, não fosse Audálio Dantas surgir em sua vida. O jornalista, ao fazer uma reportagem na favela do Canindé, tomou conhecimento da catadora de papel que relatava suas agruras quotidianas em cadernos velhos.

Surgiu, em decorrência, o best seller "Quarto de despejo: diário de uma favelada", publicado em 1960, obra que promoveu Carolina à condição efêmera de celebridade internacional e lhe permitiu concretizar o sonho de comprar uma casa.

Traduzido para 13 línguas em cerca de 40 países, incluindo nações como Japão e União Soviética (atual Federação Russa), Quarto de despejo rendeu à Carolina um grau de notoriedade suficiente a ponto de ser objeto de interesse de jornalistas brasileiros e estrangeiros e de ser levada a viagens pelo exterior. Também, a obra foi transposta para teatro e transformada em documentário na Alemanha, inédito no Brasil.

Após o fenômeno Quarto de despejo, Carolina publicou Casa de alvenaria: diário de uma ex-favelada, Pedaços da Fome e Provérbios, entretanto sem alcançar o sucesso de seu livro de estreia. Vítima das circunstâncias desfavoráveis para alguém de suas origens e, até certo ponto, do próprio sucesso, Carolina acabou por se isolar em uma chácara adquirida na área rural da região de Parelheiros, extrema zona sul de São Paulo, onde passou os últimos anos de sua vida em condições bastante precárias e veio a falecer de asma, aos 63 anos, em 13 de fevereiro de 1977.

Carolina não foi a primeira pessoa pobre a se enveredar pela literatura, tampouco a primeira negra ou de origem negra, mas Quarto de despejo é a primeira obra escrita sobre a favela com um olhar de dentro. Quarto, portanto, tem o pioneirismo de ser escrito por alguém que fazia parte da favela, com um olhar por vezes ácido e desencantado. Quarto de 
despejo é uma narrativa sufocante, triste, dolorida, crua, que pôs em relevo a mais excruciante chaga de uma sociedade: a miséria.

Ademais, em Quarto de despejo a editoração não padroniza a linguagem, como se esperaria de qualquer publicação. Apesar de ter passado por diversos cortes e outras alterações que visavam à inteligibilidade da leitura, a obra mantém grande parte das marcas de oralidade, normalmente "corrigidas" em qualquer outra publicação.

Assim sendo, grafias que reproduzem uma pronúncia não padrão, bem como casos de concordância em desacordo com as prescrições da gramática normativa e vocábulos populares e vulgares aparecem em quase todas as páginas da obra ${ }^{1}$.

No tocante à sua prosa memorialística, em especial a narrativa de Quarto de despejo, vários estudos foram realizados em diversas universidades brasileiras. Tais estudos tiveram como foco, sobretudo, a história oral e a literatura comparada. Nas teses a que tivemos acesso (parcial ou na íntegra), a questão linguística sempre é mencionada, mas superficialmente. Essas menções, não raro, são feitas dentro de uma ótica tradicional e purista, tratando as marcas de oralidade tão somente como "erros" ou "desvios gramaticais".

Acreditamos ser necessário um estudo linguístico aprofundado, que compreenda à luz das Ciências da Linguagem o tratamento linguístico que Carolina de Jesus deu à sua escrita.

Quarto de despejo é uma obra que, mesmo sendo pouco conhecida pelas gerações mais novas, causou grande impacto em sua época por causa da forma de enxergar o Brasil e o fenômeno da pobreza em plenos "anos dourados" da década de 1950.

Não temos conhecimento de um estudo específico que contemple o

1 Nas edições mais recentes, impressas pela Editora Ática, aparece a seguinte nota dos editores: "Esta edição respeita fielmente a linguagem da autora, que muitas vezes contraria a gramática, mas que por isso mesmo traduz com realismo a forma de o povo enxergar e expressar seu mundo". 
aspecto linguístico da obra. São frequentes, nos estudos realizados sob outras perspectivas, juízos sobre os "erros" ou "equívocos" gramaticais de Quarto de despejo.

No entanto, um exame não superficial de Quarto de despejo evidencia não "erros", mas a presença de marcas de oralidade. Como tais marcas se processam em nível fonológico, lexical, morfossintático e discursivo, recortamos para este trabalho as marcas lexicais, isto é, o uso expressivo de vocábulos e expressões advindos da língua falada popular, muitas vezes em cotejo e contraste com um número expressivo de vocábulos cultos ou até preciosos.

0.2 - A estrutura da dissertação

Procurando abrir uma perspectiva de análise, esta dissertação tem o objetivo geral de investigar algumas marcas de oralidade no texto de "Quarto de despejo - diário de uma favelada", de Carolina Maria de Jesus.

A partir deste objetivo geral, dois objetivos específicos se desdobram.

Primeiro, verificar como a língua falada se manifesta em Quarto de despejo, estabelecendo relações entre fala e escrita.

Segundo, dentre as diversas marcas de oralidade presentes na narrativa, analisar as marcas lexicais, arrolando e discutindo critérios para compreender o fenômeno da oralidade no nível lexical.

Tendo em vista o acima exposto, as seguintes perguntas nortearão esta pesquisa:

1. Determinados fenômenos, em vez de meros "desvios gramaticais", não seriam influência da língua falada cotidiana?

2. Como se processou essa influência?

3. Até que ponto há marcas de oralidade no plano lexical? 
4. Em que medida o léxico oral de Quarto de despejo é expressivo e que efeitos de sentido possui no contexto de enunciação?

5. Como compreender e explicar, ao lado da notável ocorrência de vocábulos e expressões populares, o uso de itens lexicais de uso culto e/ou precioso?

Para os problemas levantados por esse olhar sobre Quarto de despejo temos as seguintes hipóteses:

1. As construções que estão em desacordo com a gramática normativa são, na verdade, traços da língua falada que ocorrem de modo frequente e sistemático, previsíveis dentro do sistema da língua;

2. Entre os diversos traços de oralidade, podem ocorrer marcas fonológicas, lexicais ou morfossintáticas, dentre as quais destacamos as marcas lexicais.

3. Embora seja difícil estabelecer critérios para classificar o que seja de uso típico ou essencialmente "oral" em termos de vocabulário, defendemos que o léxico "popular", mesmo escrito, é tendencialmente oral. Portanto, os vocábulos (tanto lexias simples quanto lexias compostas) advindos da língua falada "popular" constituem um traço marcante de oralidade.

4. Se não todas as ocorrências, pelo menos grande parte do léxico popular presente na narrativa de Quarto de despejo é estilisticamente expressivo.

5. Diferentemente de um autor que maneja a língua na modalidade culta e nela representa conscientemente marcas da língua falada popular em narrativas literárias, em Quarto de despejo, a oralidade expressa pela autora não é planejada, mas espontânea. Sua intenção era projetar a imagem de "escritora", de "poeta", de alguém que conhecia a língua. Isso explica, em parte, seu apego pelas palavras raras, de cunho preciosista. 
Este trabalho se estrutura em cinco capítulos, distribuídos em três partes, conforme se verá a seguir:

A primeira parte, a contextualização, apresenta um capítulo que constitui uma visão geral da obra.

No capítulo 1, intitulado "Quarto de despejo: a autora e a obra", será feita uma análise biobibliográfica da trajetória da figura de Carolina Maria de Jesus, recenseando-se aspectos da escrita e publicação de sua obra. De forma breve, comentaremos a questão do gênero e arrolaremos as características linguísticas mais significativas da obra. Abordaremos as questões de grafia e de empregos peculiares ao Português Popular Escrito, tais como o uso existencial do verbo ter, a ausência de marcas de pluralização em verbos e, no nível frásico, a tendência para o emprego de períodos simples ou compostos por coordenação. Por fim, apresentaremos a questão lexical, que será o foco desta dissertação.

A segunda parte, que apresenta a fundamentação teórica desta dissertação, é constituída de três capítulos.

No capítulo 2, intitulado "Estrutura da narrativa", com base em pressupostos da Teoria Literária, será delineado o plano geral da narrativa, em que serão postos em relevo conceitos importantes para este trabalho, tais como "autor", "narrador", "enredo", "foco narrativo", "personagens e ações", "tempo e espaço", "conflito", "discurso direto", "discurso indireto" e "discurso indireto-livre".

No capítulo 3, intitulado "Formação e constituição do léxico", com base em pressupostos da Lexicologia e da Estilística, serão revistos os conceitos fundamentais ao estudo do léxico, tais como "lexia", "lexia simples", "lexia composta", "lexia complexa estável", "lexia textual", "palavras lexicais e gramaticais" e "campos semânticos". A questão lexical nos conduz a uma reflexão de natureza estilística, em que abordaremos a expressividade do léxico de uso popular.

No capítulo 4, intitulado "Discutindo as relações entre fala e escrita", 
serão postos em relevo, com base na Sociolinguística e na Pragmática, aspectos teóricos concernentes aos estudos de língua falada e língua escrita. Analisaremos a questão das variedades linguísticas e de sua relação com as modalidades falada e escrita. Será feita uma apreciação crítica acerca da questão do continuum fala/escrita e como esse pode ser aplicado à natureza do léxico. Traçaremos critérios preliminares para distinguir, ou, pelo menos, tentar distinguir o vocábulo de uso popular como tendencialmente mais oral em contraposição ao vocábulo culto, tendencialmente mais escrito, usando, para tanto, o dicionário de língua como critério preliminar, bem como uma série de características que, não excludentes e combinadas entre si, servem de norte para nossa investigação.

Na terceira parte, constituída de um capítulo, "Os usos vocabulares de Quarto de despejo", apresentaremos tanto uma proposta de análise dos traços orais lexicais em Quarto de despejo quanto uma análise da expressividade de suas escolhas lexicais, desdobrando-se em dois tópicos.

No primeiro tópico, a partir das teorias anteriormente expostas nos capítulos 2, 3 e 4, procederemos a uma análise lexical de Quarto de despejo. Esta análise será feita por amostragem, ou seja, não serão examinados todos os lexemas de traço popular em Quarto de despejo, visto que tal análise, se exequível, seria inviável do ponto de vista metodológico.

No segundo tópico, "A expressividade de um léxico em permanente colisão" 6, serão examinados, com exemplos da obra, os dois campos semânticos mais salientes na narrativa de Quarto de despejo. Será focalizado que, além da abundância de lexias de origem popular, aparece no texto um número bastante elevado de vocábulos de feição mais culta, presentes na voz da narradora. Essa tensão estilística será discutida na parte final do trabalho. 


\section{3 - Percurso metodológico}

O corpus desta pesquisa é constituído pelo livro Quarto de despejo: diário de uma favelada, exemplar da $1^{a}$ edição, de 1960, publicado pela Editora Francisco Alves.

Também consultamos Meu estranho diário, obra organizada pelos professores José Carlos Sebe Bom Meihy e Robert Levine, contendo facsímiles de parte dos manuscritos de Carolina. O livro divide-se em três partes: "No Quarto de despejo", "Na Casa de Alvenaria" e "No sítio", com reproduções dos diários escritos em fases diferentes da vida de Carolina. Trabalhamos com a primeira parte, que contém as entradas do diário entre 30 de outubro de 1958 e 4 de dezembro de 1958.

A escolha de Meu estranho diário, conforme se verificará no decorrer desta dissertação, se justifica por recuperar trechos do que Carolina escreveu, sem os cortes, correções e outras intervenções editoriais realizadas por Audálio Dantas para a edição do Quarto de despejo. Acreditamos que essa visão dos trechos inéditos contribui para acurar a nossa análise.

Como parte dos manuscritos originais foi perdida $e$ os remanescentes estão na Biblioteca Nacional do Rio de Janeiro, contamos com um importante trabalho realizado pela Profa Dra Elzira Divina Perpétua (UFMG) que, para a redação da tese de doutorado "Traços de Carolina Maria de Jesus: gênese, tradução e recepção de Quarto de despejo", teve a oportunidade de ler e microfilmar parte desses manuscritos, disponibilizados em anexo ao seu trabalho.

Dessa forma, cotejando a edição de Quarto de despejo com Meu estranho diário, apesar dos muitos cortes efetuados para a edição em livro, a organização textual da autora (pelo menos em termos estritamente lexicais) não ficou comprometida, o que - em nosso entendimento - contribui para validar o corpus desta pesquisa. 
Quarto de despejo foi escaneado e salvo em arquivo word, para fins de levantamento das ocorrências. Como se trata de um estudo com foco lexical, foram assinalados e fichados os lexemas mais significativos dentro da obra, cuja enunciação pareça de uso típico na língua falada popular. Para garantir que nenhum vocábulo fosse excluído, escaneamos o texto na íntegra em formato PDF e salvamos uma cópia em formato word. Usando o recurso do word de localizar palavras, pudemos numerar com exatidão a frequência das palavras lexicais que formam o objeto de análise deste estudo.

Após o fichamento, suas ocorrências e significados foram consultados em dicionários de língua e de gíria, como critério inicial para sua origem popular. Paralelamente ao léxico popular, será anotado também o léxico mais culto (ou, eventualmente, mais precioso) que aparece na obra.

Em uma primeira etapa, munidos de marca-textos, fizemos uma leitura minuciosa e atenta, assinalando com cores diferentes vocábulos populares e cultos. Organizamos fichas com essas palavras, dispondo-as em ordem alfabética e assinalando as suas ocorrências e o contexto dentro da obra, com número de página e linha.

Sequencialmente, fizemos uma tabela com essas ocorrências e consultamos dicionários a fim de determinar com precisão o registro, nível linguístico e significado desses vocábulos. Para tanto, privilegiamos obras com proximidade do momento de enunciação, a década de 1950. Escolhemos o Novíssimo Dicionário da Língua Portuguesa, edição brasileira, de Caldas Aulete, de 1958. Outras obras lexicográficas serviram de referencial para esse momento da pesquisa: o Novo dicionário da gíria brasileira, de Manuel Viotti, de 1958, A gíria brasileira, de Antenor Nascentes, de 1953, a primeira edição do Dicionário Aurélio da Língua Portuguesa, de 1975, bem como a edição de 2011. Como obra contemporânea, a fim de verificar se esses vocábulos continuam em uso e com as mesmas acepções, consultamos a primeira edição do Dicionário 
Houaiss. Ressaltamos a importância do Dicionário de gíria de J. B. Serra e Gurgel, edição de 1993. Não obstante seja publicação muito posterior à década de 60, muitos dos vocábulos consignados como gírios pelo autor encontram-se em Quarto de despejo, o que consideramos altamente significativo, visto que tal vocabulário permanece em uso na esfera da língua falada.

Após a elaboração da tabela e a consulta às obras de referência em questão, fizemos uma segunda tabela no processador de textos word e manualmente arrolamos as palavras lexicais que ocorrem na obra, isto é, substantivos, verbos e adjetivos. Depois de elaborada essa planilha, selecionamos e colocamos todas essas palavras em ordem alfabética.

Enfatizamos que o leitor será poupado dessa estatística, a fim de não corrermos o risco de um desvio do foco de análise (não se trata de uma análise quantitativa).

Com esse material em mãos, procedemos a uma leitura cuidadosa de textos de Sociolinguística, Pragmática e Estilística, as teorias linguísticas que fundamentam nosso estudo, bem como de obras que propiciassem uma contextualização do nosso corpus.

As citações de Quarto de despejo e Meu estranho diário obedecerão ao seguinte formato: todos itens lexicais em análise serão reproduzidos em contexto, com indicação da entrada (dia, mês e ano de referência), número da respectiva página no livro e número das linhas que abrangem a citação. Às citações do corpus, reproduzidas em contexto, chamaremos de "entradas", em referência às datas que constam na narrativa.

Para facilitar a leitura e a visualização dos trechos em análise, optamos por reproduzi-los em parágrafo normal, sem o recuo característico de $4 \mathrm{~cm}$ para citações, com corpo de tamanho 10 . Os trechos de Quarto de despejo serão reproduzidos em tipo normal, com os itens lexicais em negrito. Por outro lado, as citações extraídas do livro Meu estranho diário serão reproduzidas totalmente em tipo itálico 
(mantendo-se o critério anterior do negrito para o léxico) e igualmente seguidas pelo número de página.

Optamos por analisar os itens lexicais por ordem de ocorrência no texto, e não por ordem alfabética. Para compensar uma eventual dificuldade que esse critério venha a acarretar, elaboramos um glossário em apêndice antes das indicações bibliográficas.

Ressalvamos que, embora em desacordo com as normas da ABNT, optamos por um espaçamento de $06 \mathrm{~cm}$ depois de cada parágrafo com o objetivo de aperfeiçoar a legibilidade do texto, inclusive das referências bibliográficas. As citações em língua estrangeira (francês e espanhol) serão traduzidas em notas de rodapé. 
PRIMEIRA PARTE - CONTEXTUALIZAÇÃo 


\section{CAPÍTULO 1 - QUARTO DE DESPEJO: A AUTORA E SUA OBRA}

Quem foi Carolina Maria de Jesus? Por que examinar seus escritos? Como se estrutura sua obra e quais suas qualidades distintivas fundamentais?

Neste capítulo, procuraremos responder a essas perguntas apresentando um esboço biográfico da autora, o plano geral da obra e uma breve exposição de suas características linguísticas mais notórias.

\section{1 - A saga da "Cinderela negra"}

Carolina Maria de Jesus nasceu em Sacramento (MG), no dia 14 de março de 1914. Neta de escravos e oriunda de uma família negra em situação de penúria, estudou apenas os dois primeiros anos do ensino fundamental (na época chamado de curso primário) no Colégio Espírita Allan Kardec, em sua cidade natal, graças a uma benfeitora.

Apesar dos estudos incompletos, Carolina tomou gosto pelos livros e pelo universo da escrita; com os anos, mesmo de forma rudimentar, passou a tomar notas de seu quotidiano em forma de diário, além de escrever poemas e contos.

Depois de adulta, Carolina saiu de sua cidade e, após perambular por várias cidades do interior do estado de São Paulo, fixou-se na capital. No final dos anos 40, após um período na cidade paulista de Franca, Carolina buscou, na cidade de São Paulo, alcançar uma vida melhor, conforme suas palavras no Diário de Bitita, escrito posterior a Quarto de despejo e publicado postumamente:

No dia da viagem, não dormi para não perder o horário. O trem saía às sete horas, mas eu cheguei na estação às cinco horas. Que alegria quando embarquei! Quando cheguei à capital, gostei da cidade porque São Paulo é o eixo do Brasil. É a espinha dorsal do nosso país. Quantos políticos! Que cidade progressista. São Paulo deve ser o figurino para este país se transforme num bom Brasil 
para os brasileiros. Rezava agradecendo a Deus e pedindo-lhe a proteção. Quem sabe ia conseguir meios para comprar uma casinha e viver o resto dos meus dias com tranquilidade.." (JESUS, 1986, p. 202-203)

Suas expectativas, não obstante, não viriam a se concretizar. Sem trabalho nem oportunidades, entre 1947 e 1948 construiu um barraco de madeira na favela do Canindé, às margens do rio Tietê, morando nele com os três filhos, frutos de relacionamentos fortuitos: João José, José Carlos e Vera Eunice.

Mesmo diante de circunstâncias extremamente desfavoráveis, Carolina nunca deixou de ler, colecionar livros e revistas e cultivar a escrita. Dos papéis que recolhia nas ruas, guardava alguns para seu uso e neles anotava exaustivamente os acontecimentos e suas impressões, bem como poemas e contos ${ }^{2}$.

Carolina, apesar da luta pela sobrevivência, possuía uma distinção: gostava de ler, escrever e ter livros. Vamos encontrar em Quarto de despejo diversas referências ao universo da leitura e da escrita.

Em diversas entradas encontramos reflexões da narradora sobre o universo da leitura e da escrita, em que faz referência à sua prática de leitura e escrita.

Na passagem a seguir, de 19 de julho de 1955, após relatar um desentendimento com mulheres da favela, em quem seus filhos jogaram pedras, a narradora menciona:

19 de julho de 1955 (...) Os meus filhos estão defendendo-me. Vocês são incultas, não pode compreender. Vou escrever um livro referente a favela. Hei de citar tudo que aqui se passa. E tudo que vocês me fazem. Eu quero escrever o livro, e vocês com estas cenas desagradáveis me fornece os argumentos. (p. 21, linhas 10-15)

Em sua visão, a escrita implica o compromisso de relatar tudo o que acontece em seu entorno, o que novamente irá se repetir logo adiante, na seguinte passagem, na entrada de 25 de julho de 1955, na qual dispensa um pretendente sob a alegação de que não dispõe de tempo para 
relacionamentos amorosos porque está escrevendo um livro:

25 de julho de 1955 (...) Seu Gino veio dizer-me para eu ir no quarto dele. Que eu estou the desprezando. Disse-Ihe: Não! É que eu estou escrevendo um livro, para vendê-lo. Viso com esse dinheiro comprar um terreno para eu sair da favela. Não tenho tempo para ir na casa de ninguém. (p. 28, linhas 29-33)

As duas passagens possuem a mesma tônica: constituem reflexões sobre o ato de escrever. Na segunda, percebemos a aspiração de ter seus escritos reconhecidos, pois em sua visão a literatura era o passaporte que Ihe garantiria usufruir uma vida melhor, sair da favela e ter a sua própria casa.

A prosa memorialística é caminho trilhado por forças das circunstâncias (visto que a própria autora em diversas passagens se autorreferencia como "poeta"3), mas é a porta que se lhe abriu por meio de Audálio Dantas.

Em abril de 1958, aos 44 anos, Carolina foi descoberta pelo jornalista Audálio Dantas (DANTAS, 1961, p. 5), que, nos dois anos seguintes, leu os manuscritos e fez procedimentos editoriais visando à publicação, que se concretizaria em 1960, pela Editora Francisco Alves.

Aos 46 anos, Carolina se viu repentinamente alçada à condição de celebridade, e Quarto de despejo - diário de uma favelada alcançou notável sucesso editorial, conforme atestam Meihy e Levine:

As 182 páginas de Quarto de despejo foram publicadas em 13 línguas em mais de 40 países, incluindo a então União Soviética e o Japão. Sua projeção foi vertiginosa, e jamais outro livro publicado no Brasil com testemunhos de mulheres pobres alcançou níveis equiparáveis ao de Carolina. (MEIHY; LEVINE, 1994, p. 26)

Quarto de despejo é a compilação de parte das memórias de Carolina, entre o período de 15 de junho de 1955 e 1 de janeiro de 1960, com um hiato de três anos e diversas lacunas temporais ${ }^{4}$, conforme

3 Por exemplo, nesta referência à página 40: "Os políticos sabem que eu sou poetisa. E que o poeta enfrenta a morte quando vê o seu povo oprimido". (p. 40)

4 Tais lacunas se devem ao processo de editoração. Audálio Dantas cortou inúmeros trechos que julgou desnecessários para publicação, tendo em vista a quantidade de 
podemos visualizar no quadro abaixo:

Tabela 01 - Organização de Quarto de despejo

\begin{tabular}{|l|l|l|}
\hline \multicolumn{1}{|c|}{ Ano } & \multicolumn{1}{c|}{ Início } & \multicolumn{1}{c|}{ Término } \\
\hline 1955 & 15 de julho & 28 de julho \\
\hline 1958 & 2 de maio & 31 de dezembro \\
\hline $1959-1960$ & 1 de janeiro de 1959 & 1 de janeiro de 1960 \\
\hline
\end{tabular}

O dia a dia de Carolina e seus filhos na favela do Canindé, a luta pela sobrevivência, o convívio (na maior parte pontuado pela agressividade) com seus vizinhos e referências nem sempre elogiosas a políticos da época, como Adhemar de Barros, Jânio Quadros e Carlos Lacerda, por exemplo, descortinam-se diante do leitor numa narrativa que revela uma vida atribulada e sem perspectivas.

O título, atribuído por Audálio Dantas, toma como referência a expressiva metáfora de Carolina sobre a favela, que aparece a primeira vez na entrada de 19 de maio de 1958:

19 de maio de 1958 (...) As oito e meia da noite eu já estava na favela respirando

cadernos. Na realidade, não há um critério definido para essa seleção do material, que foi feita aleatoriamente. A esse respeito, Dantas afirma no prefácio do livro: "Os originais que contém o diário agora publicado estão em vinte cadernos, quase todos encontrados no lixo. Há até um que antes serviu para registro de compras e outro para registro de despesas operativas. Lendo-os, quando o tempo sobrava um pouco, demorei uns dois meses. Depois, selecionei trechos, sem alterar uma palavra, para compor o livro. Explico: Carolina conta o seu dia inteiro, com todos os incidentes, fiel até ao ato de mexer o feijão na panela. A repetição seria inútil. Daí, a necessidade de cortar, selecionar as histórias mais interessantes... Como essa história que conto e garanto é o exato acontecido, tenho de acrescentar que, em alguns poucos trechos, botei uma ou outra vírgula, para evitar interpretação dúbia de frases. Algumas cedilhas desapareceram, por desnecessárias, e o verbo haver, que Carolina entende apenas com um a assim soltinho, confundido facilmente com o artigo, ganhou um $\boldsymbol{h}$ de presente... De meu, no livro, há ainda uns pontinhos que aparecem assim (...) e indicam supressão de frases. Quando os pontinhos estão sozinhos, sem (), nos parágrafos querem dizer que foi suprimido um trecho ou mais da narrativa original." (DANTAS, 1960, p. 11, grifos nossos) Embora Carolina tenha escrito seus diários anos a fio, Quarto de despejo contempla um período relativamente limitado: 13 dias em 1955, 7 meses em 1958 e o ano de 1959, totalizando menos de dois anos. Mesmo nos dias publicados, há inúmeras marcas de parênteses com reticências indicando cortes realizados por Audálio Dantas. Segundo ele, durante o período entre julho de 1955 e maio de 1958, Carolina ficou sem escrever. Infelizmente não podemos comprovar a veracidade dessa afirmação. 
o odor dos excrementos que mescla com o barro podre. Quando estou na cidade tenho a impressão que estou na sala de visita com seus lustres de cristais, seus tapetes de viludos, almofadas de citim. E quando estou na favela tenho a impressão que sou um objeto fora de uso, digno de estar num Quarto de despejo. (p. 37, linhas 30-36, grifos nossos)

Carolina continuou escrevendo e, no ano seguinte, 1961, saiu Casa de alvenaria - diário de uma ex-favelada, relato de seu quotidiano a partir da publicação do Quarto, pormenorizando a rotina do lançamento e sua mudança com os filhos para a casa própria no bairro do Imirim, zona norte de São Paulo, a "casa de alvenaria" a que alude o título.

Em 1963, sairia seu terceiro livro, Provérbios, publicado às próprias custas, descrito por Meihy e Levine como:

\begin{abstract}
um apanhado de dizeres populares, popularescos ou popularizados, na base de passagens como a seguinte: 'apenas os fortes sabem como vencer as vicissitudes da vida'. Uma tônica moral revestia cada página como uma espécie de instrução de como vencer na vida. (...) Tudo virava lugar-comum, e frases como 'o grande espetáculo dos pobres hoje é ter o suficiente para comer em casa' caíam numa rotina gasta ${ }^{5}$. (MEIHY; LEVINE, 1994, p.35)
\end{abstract}

Ainda em 1963, Carolina publicou um romance, Pedaços da fome, às próprias expensas e igualmente um fracasso editorial. Nenhum de seus esforços para se manter em evidência impediu que gradualmente caísse no esquecimento.

Arrefecida a euforia pela novidade de Quarto de despejo, Carolina já não causava interesse como antes e sua obra subsequente não teve, nem de longe, o mesmo impacto do livro de estreia.

Sua vida na "casa de alvenaria" não deu certo. Vítima da hostilidade da vizinhança e da sua própria dificuldade em administrar a nova vida, Carolina vendeu a casa e, em 1969, comprou um sítio na parte rural de Parelheiros, extrema zona sul de São Paulo, onde morreria em 1977, aos

5 Os dois exemplos citados por Meihy e Levine não nos parecem necessariamente provérbios, no sentido estrito do termo, mas um apanhado de frases de cunho proverbial. Item raro, esse livro se encontra esgotado e é difícil de ser encontrado, daí nos pautarmos exclusivamente na citação dos autores. Talvez a leitura da obra ensejasse outra visão. 
63 anos, de parada respiratória decorrente de uma crise de asma.

Apesar das vicissitudes de sua trajetória de Cinderela às avessas, havia um público estrangeiro interessado em sua obra. Em entrevista concedida pouco antes de sua morte, Carolina doou a jornalistas franceses manuscritos que faziam parte de um novo projeto, cujo título seria Um Brasil para os brasileiros, livro de memórias em que ela narrava sua vida desde a infância até a vinda para São Paulo.

Publicado postumamente na França, em 1982, com o título de Diário de Bitita, a obra foi lançada no Brasil pela Editora Nova Fronteira em 1986. O Diário de Bitita é considerado por Meihy e Levine como uma obra "cheia de passagens interessantes sobre a vida rural, sobre a brutalidade dos políticos e sobre as expectativas afloradas desde o surgimento de Vargas na cena política de 1930." (MEIHY; LEVINE, 1994, p. 45)

Nos manuscritos de Carolina também havia um grande número de poemas, que foram compilados por José Carlos Sebe Bom Meihy e publicados pela editora da UFRJ em 1994, com o título Antologia pessoal, dezessete anos após a morte da autora, em comemoração pela efeméride dos seus 80 anos de nascimento.

Segundo sua filha Vera Eunice, em entrevista a nós concedida ${ }^{6}$, Carolina ainda escreveu outras obras, cujos manuscritos inéditos foram doados à prefeitura de Sacramento, onde há um museu sobre sua vida e obra. Os manuscritos de Quarto de despejo, até pouco tempo ainda em poder de Audálio Dantas, foram doados à Biblioteca Nacional, no Rio de Janeiro, onde foram digitalizados e disponibilizados para eventuais pesquisadores.

6 Vera Eunice nos concedeu uma entrevista em 5 de fevereiro de 2012 para a realização deste trabalho. Vera Eunice de Jesus Lima é professora, com licenciatura plena em Letras (Português e Inglês) e em Pedagogia. É professora de português da rede estadual e de educação infantil na rede municipal da cidade de São Paulo. Nasceu em 15 de julho de 1953, quando Carolina ainda morava na favela. A entrevista nos foi concedida na EE Mário Arminante, na região de Parelheiros, onde trabalha no período noturno. 
1.2 - Quarto de desejo: as faces da narrativa de Carolina

Quarto de despejo suscita uma questão inescapável: sua função é referencial ou poética? Em outros termos, é um texto documental, histórico, não literário, ou um texto artístico, cuja linguagem o arremete para a literatura e, portanto, para os domínios estéticos?

A linguagem e os elementos expressivos aproximam a narrativa autobiográfica da literatura. É possível afirmar que os dois aspectos (o referencial e o poético) não se excluam, mas se complementem, fazendo de uma narrativa como Quarto de despejo um texto híbrido, em termos de literário versus não literário. De acordo com Ginzburg,

sendo a autobiografia um espaço de reflexão do eu sobre sua própria constituição, o sujeito poderia, dentro desse espaço, manejar os recursos disponibilizados pela memória, de modo a expor a percepção que considera mais adequada de sua própria imagem. Ninguém poderia, tanto como o próprio eu, caracterizar sua identidade e atribuir sentido à sua experiência. (GINZBURG, 2009, p. 124)

Essa "reflexão do eu sobre sua própria constituição" se enuncia pela linguagem e, como tal, está sujeita a moldes tradicionalmente préestabelecidos do gênero, bem como às próprias inclinações e à competência linguística do enunciador. Tais "recursos disponibilizados pela memória" e a "percepção da própria linguagem" estão intimamente relacionados ao (s) aspecto (s) linguístico (s).

Lembramo-nos de Bakhtin, para quem

a utilização da língua efetua-se em forma de enunciados (orais e escritos), concretos e únicos, que emanam dos integrantes duma ou doutra esfera da atividade humana. O enunciado reflete as condições específicas e as finalidades de cada uma dessas esferas, não só por seu conteúdo (temático) e por seu estilo verbal, ou seja, pela seleção operada nos recursos da língua - recursos lexicais, fraseológicos e gramaticais -, mas também, e sobretudo, por sua construção composicional. Esses três elementos (conteúdo temático, estilo e construção composicional) fundem-se indissoluvelmente no todo do enunciado, e todos eles são marcados pela especificidade de uma esfera de comunicação. (BAKHTIN, 1997, p. 279)

O discurso autobiográfico emerge como uma confissão, não apenas 
como uma volta ao passado, por meio de uma narrativa que recupera um pretérito não necessariamente distante ${ }^{7}$, mas, no caso específico de Carolina, uma narrativa autobiográfica que se constrói durante o desenrolar dos acontecimentos.

É inevitável que a elaboração do discurso reflita não só a estrutura do gênero (a composicionalidade e a especificidade a que alude Bakhtin), como também o contexto de produção. Parece-nos natural que uma narrativa enunciada nas condições de Quarto de despejo apresente traços de oralidade: parece fluir como um solilóquio, uma conversa do enunciador consigo mesmo, um ato enunciativo em que a linguagem flui de maneira espontânea

Paralelamente, elementos estruturais da organização textual podem ser estilisticamente expressivos. Assim, podem se estabelecer relações de similaridade (metafóricas) ou contiguidade (metonímicas) no vocabulário do texto ou serem empregados recursos típicos da língua falada, que conferem ao texto maior dinamicidade e proporcionam maior envolvimento do leitor.

Essa não é uma condição exclusiva da língua literária, mas esta é a instância por excelência de sua exploração estilística, de forma ampla e sistemática, extrapolando os limites imaginários entre a norma e o sistema da língua.

Em Quarto de despejo, autora e narradora são instâncias que se confundem: é possível separar o narrador da figura de Carolina? Em várias passagens a narradora se autorreferencia pelo nome próprio e até se identifica, como nesta passagem da entrada de 19 de julho de 1955:

19 de julho de 1955 (...) Estive revendo os aborrecimentos que tive esses dias. Suporto as contingências da vida resoluta. Eu não consegui armazenar para viver, resolvi armazenar paciência.

Nunca feri ninguém. Tenho muito senso! Não quero ter processos. O meu registro geral é 845.936. (p. 19, linhas 26-30) 
Quarto de despejo vai além do mero aspecto documental, constituindo uma narrativa particularizante, em que a narradora deixa suas marcas pessoais e procura imbricar a escrita com a realidade, a fim de firmar um pacto de veracidade. Carolina, como diz Sousa,

procura revelar a sua identidade, não mais a subjetiva, o eu
interno, ou o eu narrativo, mas um eu identificado objetivamente
pelo documento atestado na Secretaria de Segurança Pública.
Extrapola a esfera do privado, do diário como narrativa íntima, e
apela para a biografia, narrativa em que documenta a sua
existência. (SOUSA, 2012, p. 157)

O estatuto de texto literário de Quarto de despejo, a nosso ver, não está centrada na questão do seu gênero discursivo, mas em sua linguagem, no modo de enunciação, em como a língua é posta em atividade pela autora-narradora.

Segundo Spengemann, as Confissões de Santo Agostinho constituíram o primeiro grande texto autobiográfico do Ocidente, que possuí três características básicas: "a lembrança histórica de si mesmo, a auto-investigação filosófica e a auto-expressão poética". (SPENGEMANN apud BARROS, 2006, p. 26)

Encontramos, mutatis mutandis, os mesmos elementos em Quarto de despejo. A "lembrança histórica de si" é tecida concomitantemente aos acontecimentos, por meio da narração das experiências quotidianas da narradora enquanto personagem principal do próprio relato. A autoinvestigação filosófica toma corpo nas digressões, em que a narradora tece suas impressões sobre temas existenciais. Essas digressões também dimensionam uma "auto-expressão poética" da narradora, com diversas inflexões líricas ao longo da narrativa.

A linguagem de Quarto de despejo se caracteriza por uma ambivalência de níveis de linguagem, em que o nível culto e o popular se cruzam reciprocamente na voz da narradora e cede a vez para o registro popular na voz dos personagens, incluindo a si própria.

É a condição sociocultural de Carolina que confere à narrativa de Quarto de despejo um estatuto sui generis, ao dar vez a construções 
sofisticadas, vazadas no cânon literário do século XIX.

De modo bastante peculiar, a linguagem de Quarto de despejo apresenta uma acentuada oscilação de nível de registro, indo do culto precioso ao quase vulgar, em alguns momentos no mesmo parágrafo. É essa oscilação linguística que confere a Quarto de despejo o estatuto de texto literário. Essa ambivalência linguística será objeto de nossas reflexões oportunamente.

Considerando-se Quarto de despejo uma narrativa literária, faz-se oportuno observar que a autora não escolhe o artigo de jornal ou qualquer outro gênero textual fora da literatura para se legitimar como escritora. Parece-nos possível, portanto, a referência a Maingueneau, para quem

o discurso literário é um discurso constituinte, isto é, um discurso que legitima uma língua. Os discursos constituintes são discursos que conferem sentido aos atos da coletividade (...). O jornalista, às voltas com um debate social, vai recorrer assim à autoridade do sábio, do teólogo, do escritor ou do filósofo - mas o contrário não acontece. Esses discursos são, portanto, dotados de um estatuto singular: zonas de fala entre outras e falas que se pretendem superiores a todas as outras. (MAINGUENEAU, 2006, p. 61, grifos nossos)

A literatura possui um estatuto privilegiado em relação a outras formas de escrita na sociedade. Deste modo, o discurso literário possui o estatuto de legitimador da escrita e é esse o modelo discursivo de Carolina, que pretende conquistar espaço na sociedade por meio da literatura, ocupando o papel social de "escritora", de "poeta".

Este é, inequivocamente, o objetivo de Carolina: autoafirmar-se por meio da literatura, dada a condição intrínseca de discurso constituinte da língua. A narrativa do discurso autobiográfico é o instrumento encontrado pela autora para Ihe proporcionar a sensação de pertencimento à língua como meio de expressão pessoal.

Naturalmente, a narrativa de Quarto de despejo esbarra nas convenções normativas (gramaticais) da escrita. O texto de Carolina, 
embora notável pelos vestígios de uma refinada cultura paraescolar ${ }^{8}$, não é tecido regularmente em uma linguagem considerada padrão, e apresenta variações próprias da língua oral popular, modalidade linguística não reconhecida de modo geral como molde legítimo para a expressão literária.

Entendemos Quarto de despejo como um discurso fronteiriço, que possui um duplo aspecto: transita entre a literatura e o real, e oscila entre distintos níveis de linguagem.

1.3 - Carolina Maria de Jesus e o português popular escrito de Quarto de despejo: panorama linguístico da obra

À medida que o seu diário foi tomando corpo, Carolina fez uso de um leque variado de vocábulos de feição popular, bem como de outros de feição culta ou preciosa. Há também marcas ortográficas que sugerem uma pronúncia não culta, bem como uma série de desvios de natureza morfossintática.

Quarto de despejo, devido a essas condições, emerge como um documento importante para o estudo do português popular escrito e de investigações de como a língua falada pode deixar marcas salientes no texto.

O diário possui uma estrutura discursiva que parece simular uma intimidade entre enunciador e enunciatário, como se aquele fizesse uma confissão a este, mediatizado por uma linguagem acentuadamente informal e linguisticamente distensa.

As condições socioculturais de Carolina determinam, em certa medida, a construção da sua narrativa. Embora fosse uma pessoa de

8 Chamamos de cultura paraescolar à memória discursiva de um falante que não desenvolveu sua competência linguística em uma escolarização regular. Esse processo se dá pela leitura autodidata de livros, jornais, revistas e outros textos escritos que, embora façam parte do contexto escolar, não foram apropriados pelo falante por meio de uma escolarização formal. 
muitas práticas de leitura, a insuficiência de escolaridade deixou marcas em sua escrita durante o período em que morou na favela do Canindé.

Apresentaremos agora um panorama da obra, no qual serão brevemente examinadas as suas características linguísticas.

No âmbito da grafia, assinalamos vários casos notórios de alteração de grafemas e de ditongação de monossílabos, com o desenvolvimento de vogal epentética; esses usos peculiares sugerem a representação de uma pronúncia em não conformidade com a norma padrão. São salientes também as alterações gráficas resultantes da existência de mais de um grafema para representar um único fonema.

No tocante aos aspectos morfossintáticos, notamos o uso existencial do verbo ter, a pluralização parcial de alguns sintagmas e a simplificação frasal. Tais características enquadram a narrativa de Quarto de despejo no âmbito do Português Popular Escrito.

$E$, por fim, usos lexicais que revelam uma forte influência da língua falada popular.

Vejamos brevemente tais ocorrências:

\subsection{1 - Rotacismos}

Ainda que sejam pouco numerosos em Quarto de despejo, há casos de rotacismo em algumas passagens. Rotacismo é a substituição do fonema $^{9}$ /l/ pelo / $r$ / alveolar e aqui destacamos seis ocorrências: no vocábulo implicar e cognatos (cinco ocorrências) e no vocábulo aglomeração (uma ocorrência):

17 de julho de 1955 (...) Hoje é a Nair Mathias quem começou impricar com meus filhos. (p. 15, linha 15) [implicar]

9 Dificuldades de ordem tipográfica impediram a transcrição dos fonemas segundo as convenções da Fonologia. Embora inconveniente, adotamos o critério de Mattoso Câmara (Para o estudo da fonêmica portuguesa) de transcrever os fonemas usando o alfabeto comum entre barras. 
18 de julho de 1955 (...) A D. Rosa, assim que viu o meu filho José Carlos, começou impricar com ele. (p. 16, linhas 29-30) [implicar]

20 de julho de 1955 (...) Aqui, todas impricam comigo. Dizem que falo muito bem. Que sei atrair os homens. (p. 24, linhas 07-08) [implicam]

24 de julho de 1955 (...) Quando cheguei em casa encontrei a D. Francisca brigando com meu filho João José. Uma mulher de quarenta anos discutindo com uma criança de seis anos. Puis o menino para dentro e fechei o portão. Ela continuou falando. Para fazer ela calar é preciso the dizer:

- Cala a boca tuberculosa!

Não gosto de aludir os males físicos porquem ninguém tem culpa de adquirir moléstias contagiosas. Mas quando a gente percebe que não pode tolerar a impricância do analfabeto, apela para as enfermidades. (p. 27, linha 28 - p. 28, linha linha 2) [implicância]

22 de junho de 1958 (...) Apareceu um preto alto e gordo como se fosse decendente de elefante. Falava para todos ouvir.

- Eu não sou deputado. Sou simplesmente amigo do povo humilde.

Comecei a escrever o que observava daquela agromeração. (p. 68, linhas 34-35) [aglomeração]

3 de julho de 1958 (...) Ele anda dizendo que vai bater no menino. Se fosse uma repreensão justa, mas a dele é impricância. Onde é que já se viu um homem de 48 anos desafiar uma criança de 9 anos para brigar? (p. 79, linha 13) [implicância]

O rotacismo é uma mudança fonética bastante antiga no português e ocorre não só em vocábulos essencialmente vernáculos, mas também em empréstimos de outras línguas.

Podemos citar dois exemplos sugestivos: armazém, do árabe, almahazén, "botica, celeiro, sótão, entreposto"; branco, do germânico, blanck, "brilhante, límpido".

Nos dois exemplos houve o mesmo fenômeno fonético que aparece em Quarto de despejo, isto é, a troca de fonema materializada pela troca dos respectivos grafemas.

Embora esta seja uma perspectiva fundamentalmente diacrônica, acreditamos que sirva para ilustrar fatos pertinentes à sincronia: certos fenômenos inerentes à história da língua são absolutamente naturais e 
ocorrem na língua falada popular.

Ressaltamos que esses casos de rotacismo, típicos da fala popular, não são exemplos de evolução fonética, mas de variação linguística. Porém, embora se trate de um registro em desacordo com a norma padrão, segue um curso compreensível e previsível no sistema da língua.

\subsection{2 - A substituição de "e" por "i"}

Bastante numerosas em Quarto de despejo são os casos de variação da vogal /e/ pela vogal/i/ em posição átona ou pretônica.

Entre muitas ocorrências, destacamos dez, em destaque nas entradas a seguir:

17 de julho de 1955 (...) Quando uma senhora perguntou-me o que acho do Carlos Lacerda, respondi concientemente:

- Muito inteligente. Mas não tem iducação. É um político de cortiço. Que gosta de intriga. Um agitador. (p. 16, linhas 09-12) [educação]

18 de julho de 1955 (...) Veio a D. Silvia reclamar contra os meus filhos. Que os meus filhos são mal iducados. (p. 17, linhas 15-16) [educados]

19 de julho de 1955 (...) Quando as mulheres feras invade o meu barraco, os meus filhos thes joga pedras. Elas diz:

- Que crianças mal iducadas! (p. 21, linhas 06-08) [educadas]

24 de julho de 1955 (...) Sentei ao sol para escrever. A filha da Sílvia, uma menina de seis anos, passava e dizia:

- Está escrevendo, negra fidida!

A mãe ouvia e não repreendia. São as mães que instigam. (p. 28, linhas 07-11) [fedida]

15 de maio de 1958 (...) Os político só aparecem aqui nas épocas eleitorais. O senhor Cantídio Sampaio quando era vereador em 1953 passava os domingos aqui na favela. Ele era tão agradável. Tomava nosso café, bebia nas nossas xícaras. Ele nos dirigia as suas frases de viludo. Brincava com nossoas crianças. Deixou boas impressões por aqui e quando candidatou-se a deputado venceu. Mas não Câmara dos Deputados não criou um progeto para beneficiar o favelado. Não nos visitou mais. (p. 33, linhas $02-$ 10) [veludo] 
17 de maio de 1958 (...) Levantei nervosa. Com vontade de morrer. Já que os pobres estão mal colocados, para que viver? Será que os pobres de outro país sofrem igual aos pobres do Brasil? Eu estava discontente que até cheguei a brigar com meu filho José Carlos sem motivo. (p. 34, linhas 09-13) [descontente]

27 de maio de 1958 (...) Catei um saco de papel. Quando eu penetrei na rua Paulinho Guimarães, uma senhora me deu uns jornais. Eram limpos, eu deixei e fui para o depósito. Ia catando tudo que encontrava. Ferro, lata, carvão, tudo serve para o favelado. O Leon pegou o papel, ricibi seis cruzeiros. (p. 45, linhas 13-18) [recebi]

9 de junho de 1958 ...Eu saí. Quando eu estava catando papel em frente a Bela Vista eu tive um aviso eu eu ia ter um aborrecimento. Fiquei triste. Quando eu passava na rua Pedro Vicente um senhor deu uma bichiga de borracha para a Vera. Ela ficou contente e disse que ele ia para o céu. (p. 58, linhas 01-05) [bexiga]

16 de junho de 1958 (...) Eu escrevia peças e apresentava aos diretores de circo. Eles respondia-me:

- É pena você ser preta.

Esquecendo eles que eu adoro a minha pele negra, eu meu cabelo rústico. Eu até acho o cabelo de negro mais iducado do que o cabelo de branco. Porque o cabelo de preto onde põe, fica. É obediente. E o cabelo de branco, é só dar um movimento na cabeça, ele já sai do lugar. É indisciplinado. Se é que existe reincarnações eu quero voltar sempre preta. (p. 65, linhas 01-10) [educado; reencarnações]

Assim como a troca de /l/ por / $\mathrm{r} /$ analisada anteriormente, também não se trata de uma comutação aleatória, mas de um fenômeno regular e sistemático.

$\mathrm{Na}$ língua comum, muitos vocábulos apresentam dificuldade de escrita devido a oscilações de pronúncia. Assim, é bastante corriqueiro que alguns vocábulos apresentem variação quanto à grafia.

Em Quarto de despejo, observamos que os casos de troca de /e/ por /i/ apresentam a mesma regularidade: todos ocorrem em vogal átona ou pretônica, jamais em sílaba tônica, similarmente ao que aconteceu na diacronia e na evolução fonética da língua.

O $i$ escrito no lugar do e parece apresentar correspondência oral, aproximando a escrita de sua materialização sonora. 


\subsection{3 - A substituição de "o" por "u"}

A alternância gráfica das vogais átonas e pretônicas e e $i$ também ocorre entre as vogais /o/ e /u/, seguindo um mesmo padrão de escrita que aproxima o vocábulo de sua realização sonora. Seguem, em sequência, alguns casos:

19 de julho de 1955 (...) Hontem eu bebi uma cerveja. Hoje estou com vontade de beber outra vez. Mas não vou beber. Não quero viciar. Tenho responsabilidade. Os meus filhos! E o dinheiro gasto em cerveja faz falta para o essencial. O que eu reprovo nas favelas são os pais que mandam os filhos comprar pinga e dá as crianças para beber. $E$ diz:

- Ele tem lumbriga.(p. 22, linhas 04-11) [lombriga]

23 de julho de 1955 (...) Bateram na porta. Mandei o João José abrir e mandar entrar. Era o Seu João. Perguntou-me onde encontrar folhas de batata para buchechar um dente. Eu disse que na Purtuguesinha era possível encontrar. (p. 27, linhas 07-10) [bochechar]

21 de maio de 1958 (...) Havia um pretinho bonitinho (...) Os lixeiros haviam jogado carne no lixo. E ele escolhia uns pedaços. Disse-me:

- Leva, Carolina. Dá para comer.

Deu-me uns pedaços. Para não maguá-lo aceitei. Procurei convencê-lo a não comer aquela carne. Para comer os pães duros ruídos pelos ratos. Ele disse-me que não. Que há dois dias não comia. (p. 40, linhas 24-34) [magoá-lo; roídos]

1 de junho de 1958 É o início do mês. É o ano que deslisa. E a gente vendo os amigos morrer e outros nascer. (...) É treis e meia da manhã. Não posso durmir. Chegou o tal Vítor, o homem mais feio da favela. O representante do bicho papão. Tão feio, e tem duas mulheres. Ambas vivem juntas no mesmo barraco. (p. 49, linhas 08-13) [dormir]

11 de junho de 1958 (...) Todos os dias há uma novidade aqui na favela. Quando inaugurou a Purtuguesa de Desportos os purtugueses que reside aqui por perto foram. E a Dona Isaltina esqueceu umas roupas no quintal. No outro dia não encontrou as roupas. (p. 59, linhas 08-11) [Portuguesa, portugueses]

Essa alternância vocálica é típica do português popular escrito, conforme documentado por Pinto, que afirma:

Nesse sentido, a alteração gráfica das pretônicas e postônicas vem ratificar a debilidade dessas posições, reconhecidas desde o latim. 
No $\mathrm{PPE}^{10}$ isso ocorre sobretudo na alternância entre os fonemas /e/ e /i/, /o/ e /u/, grafados indiscriminadamente, como reflexo da fala, pouco censurada pela instrução formal ministrada pela escola. (PINTO, 2001, p. 29)

Na obra em questão, Pinto documenta vários exemplos que seguem a mesma regularidade, dos quais destacamos os seguintes: manicuri, au lado, almuçar. (op. cit., p. 30)

A constatação da autora, "reflexo da fala", particularmente nos interessa, pois se Carolina registra essas grafias trocadas, não o faz de forma aleatória ou por ignorância, mas segue uma tendência natural do português popular escrito.

\subsection{4 - A ditongação em monossílabos tônicos}

Essa tendência natural de aproximar a grafia da realização sonora da palavra ocorre também em casos de ditongação de monossílabos tônicos terminados em -s ou -z. Nesses casos, forma-se um ditongo pelo desenvolvimento da semivogal epentética $i$ após a vogal tônica, resultando em um ditongo oral descrescente. Dentre as várias ocorrências em Quarto de despejo, colhemos as seguintes (três de puis e duas de treis), a título de exemplificação:

16 de julho de 1955 (...) Peguei uma revista e sentei no capim, recebendo os raio solar para aquecer-me. Li um conto. Quando iniciei outro surgiu os meu filho pedindo pão. Escrevi um bilhete e dei ao meu filho João José para ir ao Arnaldo comprar um sabão, dois melhorais e o resto pão. Puis água no fogão para fazer café. O João retornou-se. (p. 14, linhas 31-36)

24 de julho de 1955 (...) A D. Mariana lamentava que seu esposo estava demorando a regressar. Puis as roupas para quarar e vim fazer o almoço. (p. 27, linhas 26-28)

23 de maio de 1958 (...) Antigamente era a macarronada o prato mais caro. Agora é o arroz e feijão que suplanta a macarronada. São os novos ricos. Passou para o lado 
dos fidalgos. Até vocês, feijão e arroz, nos abandona! Vocês que eram os amigos dos marginais, dos favelados, dos indigentes. Vejam só. Até o feijão nos esqueceu. Não está ao alcance dos infelizes que estão no quarto de despejo. Quem não nos despresou foi o fubá. Mas as crianças não gostam de fubá.

Quando puis a comida o João sorriu. Comeram e não aludiram a cor negra do feijão. Porque negra é a nossa vida. Negro é tudo que nos rodeia. (p. 43, linha 34 - p. 44, linha 09)

06 de junho de 1958 (...) Procurei a Vera, não encontrei. Gritei, não apareceu. Fui na Purtuguesa de Desportos. Já está iniciando os festejos juninos. Ela não estava lá. Fui no ponto de bonde treis vezes. (p. 56 , linhas $08-10$ )

08 de junho de 1958 (...) Quando nós mudamos para a favela, nós íamos pedir água nos visinhos de alvenaria. Quem nos dava água era a Dona Ida Cardoso. Treis vezes ela nos deu água. Ela nos disse que nos dava água só nos dias úteis. Aos domingos ela queria dormir até mais tarde. (p. 56, linha 32 - p. 57, linha 01)

Treis, inclusive, ocorre no corpus analisado por Pinto (op. cit., p. 30), que cita como similar a ocorrência de deis (dez).

Assim como nos casos levantados anteriormente, todas essas grafias idiossincráticas de Quarto de despejo mostram uma aproximação entre a escrita e a fala: os vocábulos são grafados como "reflexos da fala", isto é, aproximando a escrita de sua materialização fônica.

Seriam essas grafias reproduções da pronúncia de Carolina? É arriscado fazer uma afirmação taxativa, mas o contexto nos aponta para essa possibilidade.

1.3.5 - Substituições resultantes da indecisão de como representar um determinado fonema

Outro fenômeno que ocorre em Quarto de despejo é a indecisão entre as grafias $s, s s, z, x, c h$ :

No primeiro exemplo, vemos um caso de substituição do " $x$ " pelo dígrafo "ch":

17 de julho de 1955 (...) Fui torcer as minhas roupas. A D. Aparecida perguntou- 
me:

- A senhora está grávida?

- Não senhora - respondi gentilmente.

E lhe chinguei interiomente. Se estou grávida não é da sua conta. (p. 15, linhas 23-27) [xinguei]

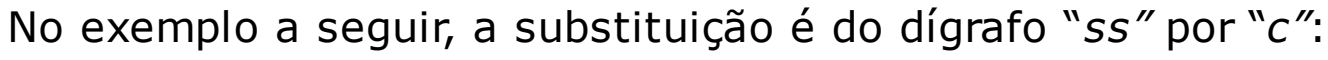

18 de julho de 1955 (...) Os meus filhos não são sustentados com pão de igreja. Eu enfrento qualquer espécie de trabalho para mantê-los. E elas [i.e., as mulheres da favela] têm que mendigar e ainda apanhar. Parece tambor. A noite enquanto elas pede socorro eu tranquilamente no meu barracão ouço valsas vienenses. Enquanto os esposos quebra as tábuas do barracão eu e meus filhos dormimos socegados. Não invejo as mulheres casadas da favela que levam vida de escravas indianas.

Não casei e não estou descontente. Os que preferiu-me eram soezes e as condições que eles me impunham eram horríveis. (p. 17, linha 33 - p. 18, linha 7) [sossegados]

No próximo caso, também comum, a substituição ocorre entre " $z$ " e "s":

22 de maio de 1958 (...) Eu hoje estou triste. Estou nervosa. Não sei se choro ou saio correndo... É que hoje amanheceu chovendo. E eu não saí para arranjar dinheiro. Passei o dia escrevendo. Sobrou macarrão, eu vou esquentar para os meninos. Cosinhei as batatas, eles comeram. (p. 42, linhas 04-09) [cozinhei]

No caso de /e/ e /i/, /o/ e /u/, não apenas os grafemas são diferentes, mas os fonemas também. Quando, porém, se troca " $s$ " por " $z$ " ou " $x$ " por " $c h$ ", trata-se do mesmo fonema sendo representado por diferentes grafemas, isto é, a narradora trocou a letra, mas não trocou o fonema. Não afirmamos categoricamente que essas grafias sejam "representações" da língua falada na escrita, entretanto essa indecisão decorre justamente de um mesmo fonema poder ser representado de maneiras tão díspares.

Seja como for, conquanto não vejamos essa indecisão entre grafias como um reflexo da fala, ela constitui uma característica típica do PPE, conforme analisado por Pinto (op. cit., p. 31), o que reforça a importância de se estudar Quarto de despejo sob a perspectiva que adotamos neste 
trabalho.

\subsection{6 - Formas verbais}

Considerado um dos traços mais salientes da língua falada é o emprego do verbo "ter" impessoal no lugar do verbo "haver" com o sentido de "existir", ao contrário do que prescreve a tradição gramatical. Embora a tradição não recomende esse uso, o emprego abundante de "ter" em lugar de haver está consagrado, tanto na língua falada quanto na língua escrita contemporânea.

Ao lado de ocorrências do verbo "haver", em Quarto de despejo a narradora emprega várias vezes o verbo "ter" com sentido existencial:

18 de julho de 1955 (...) Surgio a D. Cecília. Veio repreender os meus filhos. Lhe joguei uma direta, ela retirou-se. Eu disse:

- Tem mulher que diz saber criar os filhos, mas algumas tem filhos na cadeia classificado como mau elemento. (p. 17, linhas 03-06) [Há mulher]

18 de julho de 1955 (...) Tem a Maria José, mais conhecida por Zefa, que reside no barracão da Rua B número 9. É uma alcoólatra. Quando está gestante bebe demais. E as crianças nascem e morrem antes dos doze meses. Ela odeia-me porque os meus filhos vingam e por eu ter rádio. Um dia ela pediu-me o rádio emprestado. Disse- Ihe que não podia emprestar. Que ela não tinha filhos, podia trabalhar e comprar. (p. 18, linhas 0813) [Há a Maria José]

19 de julho de 1955 (...) Cheguei em casa, fiz o almoço. Enquanto as panelas fervia eu escrevi um pouco. Dei o almoço as crianças, e fui no Klabin catar papel. Deixei as crianças brincando no quintal. Tinha muito papel. (p. 20, linhas 17-20) [Havia muito papel]

19 de julho de 1955 (...) Que suplício catar papel atualmente! Tenho que levar a minha filha Vera Eunice. Ela está com dois anos, e não gosta de ficar em casa. Eu ponho o saco na cabeça e levo-a nos braços. Suporto o peso do saco na cabeça e suporto o peso da Vera Eunice nos braços. Tem hora que revolto-me. Depois domino-me. Ela não tem culpa de estar no mundo.

Refleti: preciso ser tolerante com os meus filhos. Eles não tem ninguém no mundo a não ser eu. Como é pungente a condição de mulher sozinha sem um homem no lar. ( $p$. 
23, linha 34 - p. 24, linha 06) [Há hora em que me revolto]

Mais uma vez o "reflexo do oral" se faz presente, desta vez no aspecto da construção frasal, com o emprego do "ter" com valor existencial, em vez de "haver".

Da mesma forma, a concordância também apresenta um uso peculiar, sem marcas de pluralização onde seria esperado, dentro da gramática normativa.

\subsection{7 - A concordância}

Marca sintática mais saliente em Quarto de despejo, é muito frequente a ausência de marcas completas de plural em sintagmas. Encontramos vários casos de sujeito flexionado no plural, com seus respectivos verbos mantidos no singular.

Vejamos alguns exemplos de concordância não padrão. Todas essas sentenças possuem basicamente a mesma estrutura Suj. (sing) + V. $(\mathrm{pl})$, e são recorrentes ao longo do relato na voz da narradora:

18 de julho de 1955 (...) Levantei as 7 horas. Alegre e contente. Depois que veio os aborrecimentos. Fui no depósito receber... 60 cruzeiros. (p. 16, linhas 24-26)

13 de maio de 1958 (...) Eu tenho tanto dó dos meus filhos. Quando eles vê as coisas de comer eles brada:

- Viva a mamãe! (p. 32, linhas 14-16)

16 de maio de 1958 Eu amanheci nervosa. Porque eu queria ficar em casa, mas eu não tinha nada para comer.

...Eu não ia comer porque o pão era pouco. Será que é só eu que levo esta vida? O que posso esperar do futuro? Um leito em Campos do Jordão. Eu quando estou com fome quero matar o Jânio, quero enforcar o Adhemar e queimar o Juscelino. As dificuldades corta o afeto do povo pelos políticos. (p. 34, linhas 01-08)

23 de maio de 1958 (...) Antigamente era a macarronada o prato mais caro. Agora é o arroz e feijão que suplanta a macarronada. São os novos ricos. Passou para o lado dos fidalgos. Até vocês, feijão e arroz, nos abandona! Vocês que eram os amigos dos marginais, dos favelados, dos indigentes. Vejam só. Até o feijão nos 
esqueceu. Não está ao alcance dos infelizes que estão no quarto de despejo.(p. 44, linha 34 - p. 45, linha 05)

Conforme podemos apreender do último exemplo (o registro de 23 de maio de 1958), a ausência de marcas de concordância não é a norma popular geral, pois em muitos casos a pluralização se dá em consonância com a norma padrão. No exemplo em questão, ao lado de "o arroz e feijão que suplanta", em vez de "suplantam", e "passou para o lado dos fidalgos", em vez de "passaram", vemos a forma "vocês que eram os amigos". Em Quarto de despejo, embora haja abundante emprego de concordância não padrão, também há momentos em que a concordância segue as prescrições da norma padrão.

É temerário arriscar uma hipótese de justificação para esse fenômeno. O contexto de produção parece indicar que, embora Carolina tivesse a intenção de uma escrita elaborada, não dominava as convenções sociais da escrita. Sua competência linguística ainda estava em construção, o que, somado a escrita concomitante aos acontecimentos, fazia com que a elaboração de sua escrita fosse praticamente nula. Parece-nos que a pluralização ao lado da não pluralização aponta para um aprimoramento gradual de sua escrita, o que irá se manifestar com maior nitidez nos escritos posteriores.

Entre diversos aspectos do Português Popular, Preti cita a "economia nas marcas de gênero, número e pessoa" (PRETI, 2003a, p. 32). Essa marcante característica do português popular em sua variante oral é frequente na escrita de Quarto de despejo, sendo mantida na versão em livro. As construções acima exemplificam casos de economia de marca de número na concordância verbal.

\subsection{8 - Nível frásico}

De acordo com Preti, a modalidade popular se caracteriza também pela 
redução do processo subordinativo em benefício da frase simples e da coordenação. (Ex: "Já disse pra você, não disse? Quando eu acabei o curso, não tinha mais dinheiro. Aí então fui trabalhar", em lugar de "Não sei se já lhe disse que, quando terminei o curso, fui trabalhar, porque não tinha mais dinheiro".) (PRETI, 2003, p. 32)

Da mesma forma como na língua falada, o texto de Quarto de despejo possui uma estrutura frásica relativamente simples. Observamos que os períodos são constituídos de frases curtas, com forte tendência para a coordenação e poucos casos de subordinação, exceto orações restritivas, explicativas, finais e temporais, que aparecem com relativa frequência.

A tendência do texto, no entanto, é para a frase nominal e para o período simples, em detrimento de períodos mais longos e sintaticamente elaborados. Vejamos dois exemplos:

16 de julho de 1955 (...) Cheguei em casa, fiz o almoço para os dois meninos. Arroz, feijão e carne. E vou sair para catar papel. Deixei as crianças. (p. 14, linhas 1214)

17 de julho de 1955 Domingo. Um dia maravilhoso. O céu azul sem nuvem. O sol está tépido. Deixei o leito às 6,30 . Fui buscar água. Fiz café. Tendo só um pedaço de pão e 3 cruzeiros. Dei um pedaço a cada um, puis o feijão no fogão que ganhei ontem do Centro Espírita da Rua Vergueiro 103. Fui lavar minhas roupas. Quando retornei do rio o feijão estava cosido. Os filhos pediram pão. Dei os 3 cruzeiros ao João José para ir comprar pão. (p. 15, linhas 07-14)

A sucessão de frases nominais e de períodos simples confere ao texto um alto poder de descrição. No primeiro exemplo, a oração subordinada é adverbial final e, no segundo, é adjetiva restritiva. São estruturas relativamente comuns, sem maior embaraço para a organização do texto.

Assim como os exemplos supracitados, há vários outros na obra. Vemos que o texto de Carolina possui as mesmas características de português popular escrito que são elencadas por Pinto (1986, p. 60-78).

Com um nível sociocultural que não the ensejou domínio da modalidade culta, o texto de Carolina oscila entre o padrão e o não 
padrão. De acordo com Pinto,

de certa maneira, o português popular escrito opõe-se ao literário: muito mais próximo da oralidade do que o escritor, o produtor de textos populares rejeita-a, em favor de um formalismo que supõe conferir-lhe status - justamente aquilo que o escritor repele, na pressuposição de que o formalismo do status literário o isolaria da oralidade, comprometendo-lhe os caminhos na aventura da criação. (PINTO, 1986, p. 78)

Embora essencialmente popular, o português escrito de Quarto de despejo não deixa de ser literário, por motivos que vamos discutir no capítulo 2. Entendemos que as duas modalidades de língua escrita não se excluem, mas que podem se inter-relacionar em um texto sui generis como o Quarto de despejo.

De certa maneira, entretanto, podemos inferir sua intenção: se, por um lado, deixa transparecer na escrita as suas origens e seu nível sociocultural, por outro, tenta reproduzir, por meio de um vocabulário rebuscado, um registro que espera Ihe proporcionar o status social de escritora.

Seja como for, essas ocorrências em Quarto de despejo são sistemáticas e não ocorrem como um mero desconhecimento de regras gramaticais. O português popular escrito, sem as amarras da convenção gramatical, está marcado pela influência da língua falada, que se manifesta na grafia que representa a pronúncia, ou mesmo por construções morfossintáticas não padronizadas.

\subsection{9 - Nível lexical}

Traço que será o recorte desta dissertação, o português popular de Quarto de despejo se manifesta, sobretudo, no plano lexical.

Ocorrem, em número bastante expressivo, vocábulos gírios, semanticamente desfocados, de uso informal, vulgar, injurioso e afetivo. Todos esses apontam para uma influência da língua falada popular na escrita. Seguem alguns exemplos, apenas a título de antevisão do 
assunto, que será aprofundado mais adiante.

Oriunda de grupos sociais restritos, a gíria de grupo penetra na língua comum como vocábulo popular. Um exemplo de vocábulo gírio:

21 de julho de 1955 (...) Passou um senhor e perguntou-me:

- O que escreve?

- Todas as lambanças que pratica os favelados, estes projetos de gente humana. (p. 24, linhas 25-28)

Vários vocábulos aparecem com seu sentido desfocado ou impreciso, que é o caso de nortista, muitas vezes empregado pejorativamente em Quarto de despejo como sinônimo de nordestino:

20 de julho de 1958 (...) Ia recomeçar escrever quando o Adalberto chegou. Veio fazer uma cerca para mim. Para evitar a entrada dos nortistas que por qualquer motivo vem aborrecer. (p. 94, linha 34 - p. 95, linha 01)

Alguns lexemas são de uso informal, típicos da linguagem oral popular ou de situações de informalidade:

10 de maio de 1959 (...) Eu não dormi porque o visinho tocou o rádio toda a noite. E a L. fez um fuá dos diabos. Ela estava dormindo com o Valdemar quando o Arnaldo chegou. (p. 159, linhas 23-25)

Típicos dos estratos mais baixos da sociedade, certos vocábulos são de uso considerado vulgar ou grosseiro. Entre as ocorrências desse tipo de vocabulário em Quarto de despejo, citamos o seguinte:

26 de setembro de 1958 (...) Ela perguntou a João se ele sabia o que era fazer porcaria. Ele disse que sabia.

E se ele havia feito porcaria na menina. Ele disse que não. (p. 120, linhas 07-10)

Muitos vocábulos são empregados para o insulto, em diálogos marcados pela agressividade. Nem todos os vocábulos são essencialmente injuriosos, mas se prestam a um uso injurioso, isto é, dependem exclusivamente do contexto de situação em que se encontra o falante. Exemplo:

16 de fevereiro de 1959 (...) Quando cheguei na favela o povo me olhava. A Dona Sebastiana chingava. Estava embriagada. Dizia que ela degolava o baiano. Eu dizia para 
ela não chegar, que ela ia morrer. Ela começou a chingar-me:

- Negra ordinária! Você não é advogada, não é repórter e se mete em tudo! (p. 153, linhas 24-29)

Há muitos vocábulos de uso afetivo, oriundos da linguagem infantil ou familiar, que denotam carinho e proximidade:

13 de maio de 1958 (...) Eu tenho tanto dó dos meus filhos. Quando eles vê as coisas de comer eles brada:

- Viva a mamãe! (p. 32, linhas 14-16)

Confirma-se, em vista do acima exposto, a nossa hipótese inicial. O que há em Quarto de despejo, mais do que inadequações gramaticais, são marcas de oralidade, que se manifestam no nível fonológico (grafia que segue de perto a pronúncia), no nível morfossintático e no nível lexical.

No tocante ao nível lexical, os vocábulos de uso popular, por serem de uso restrito na linguagem culta, parecem constituir, também, um traço de língua falada. Este último aspecto será o fulcro do presente estudo. 
SEGUNDA PARTE - FUNDAMENT AÇÃO TEÓRICA 


\title{
CAPÍTULO 2 - ESTRUTURA DA NARRATIVA
}

O ato de narrar é parte inseparável da linguagem. Seria um exercício difícil imaginar a linguagem humana sem a experiência de contar histórias, sejam elas reais sejam ficcionais. Como diz Leite, "histórias são narradas desde sempre". (LEITE, 2005, p. 5)

Mesmo que haja diversos tipos de narrativa e gêneros narrativos, alguns conceitos são comuns a todos. Para se compreender a estrutura da narrativa, é importante fazer uma primeira distinção, entre "autor" e "narrador".

Embora "autor" seja um termo muito amplo, podemos entender autor como a "entidade materialmente responsável pelo texto narrativo, sujeito de uma atividade literária a partir da qual se configura um universo diegético com as suas personagens, ações, coordenadas temporais etc". (REIS \& LOPES, 2008, p. 14)

Narrador, por outro lado, é a entidade delegada do autor, responsável pelo ato enunciativo. Para Martins, o narrador é:

\begin{abstract}
importante figura da ficção, à qual o autor delega a função de transmitir os sentidos de suas estórias, coordenando a atuação das personagens e descrevendo-as não só em sua exterioridade, mas, muitas vezes, tentando penetrar nas complexidades e mistérios de sua interioridade. (MARTINS, 2001, p. 268-269)
\end{abstract}

Ainda que Martins tenha se referido à prosa de ficção e Quarto de despejo não seja propriamente uma "estória", mas uma "história", e seu relato tenha a pretensão de reproduzir a realidade, subsiste a noção de narrador como um delegado do autor, uma instância abstrata responsável pelo enunciado.

A esse respeito, faz-se necessário entendermos o que é "enunciação" e "enunciado". Enunciação é o processo linguístico e enunciado é o resultado do processo. O autor, enquanto "entidade material", é o responsável pela enunciação, papel que compartilha com o narrador. O narrador, porém, é o único responsável pelo enunciado, pelo 
resultado concreto da enunciação. Podemos visualizar no esquema a seguir:

\section{AUTOR $\rightarrow$ ENUNCIAÇÃO \\ NARRADOR $\rightarrow$ ENUNCIAÇÃO / ENUNCIADO}

Embora em um texto autobiográfico a separação entre autor e narrador seja um tanto difusa, entendemos que nesse tipo de discurso o autor transforma a si mesmo em narrador da própria história. Ele está por trás da enunciação, confere-Ihe o fôlego da verossimilhança, mas à medida que seu relato se configura, a ficcionalidade pode imiscuir-se na realidade. Se a narradora diz que o vizinho a xingou de "negra ordinária", quem nos garante que as palavras foram textualmente essas? Não poderia seu antagonista ter usado um vocabulário ainda mais agressivo? Ela não poderia ter revidado e, por acaso, traída (ou não) pela memória, omitido de seu relato aquilo que disse enquanto personagem?

Apesar dessas reflexões, o estatuto literário de Quarto de despejo não é fundamental para nossa análise, visto que a narrativa possui uma estrutura padrão e é esse aspecto que nos importa no momento.

\section{1 - Foco narrativo: o ponto de vista do narrador}

Basicamente, uma história ${ }^{11}$ pode ser contada sob dois pontos de vista ou focos narrativos: $1^{a}$ ou $3^{a}$ pessoa. Tradicionalmente, esses pontos de vista são sintetizados como "narrador personagem" (1 ${ }^{a}$ pessoa) ou "narrador observador" ( $3^{a}$ pessoa). Entretanto, essa separação não é tão

11 Gerard Genette (Figures III, obra de 1972) cunha o termo diegese, que é "...o universo do significado, o 'mundo possível' que enquadra, valida e confere inteligibilidade à história. Assinale-se que a partir de diegese sinônimo de história formaram-se outros termos (diegético, intradiegético, homodiegético, etc.), hoje largamente difundidos e consagrados pelo uso... pensamos que os derivados de diegese devem continuar a ser utilizados para referenciar o plano da história." (REIS \& LOPES, 2002, p. 27) 
simples quanto parece e admite desdobramentos, que a moderna narratologia tratou de investigar com maior profundidade. Urbano, em estudo sobre a tipologia do narrador, aventou 20 possibilidades, embora reconheça que algumas são "de difícil ocorrência na prática". (URBANO, 2000, p. 49-50). Conforme demonstrou Carvalho (2012, p. 4 ss.), diversos teóricos se dedicaram ao assunto e propuseram terminologias diversas, que não vamos rever neste estudo. Entretanto, quatro possibilidades básicas podem ser aplicadas à maior parte das narrativas e vamos comentá-las brevemente:

1. Narrador em $1^{\text {a }}$ pessoa $\rightarrow$ narrador-protagonista

2. Narrador em $1^{\text {a }}$ pessoa $\rightarrow$ narrador-testemunha

3. Narrador em 3 a pessoa $\rightarrow$ narrador observador (limitado / visual)

4. Narrador em 3 a pessoa $\rightarrow$ narrador onisciente

Na primeira possibilidade, o narrador conta uma história na qual tomou parte ativa. Segundo Leite,

o narrador, personagem central, não tem acesso ao estado mental das demais personagens. Narra de um centro fixo, limitado quase que exclusivamente às suas percepções, pensamentos e sentimentos. (LEITE, 2005, p. 43)

Um exemplo clássico desse recurso é a narrativa de Memórias Póstumas de Brás Cubas, de Machado de Assis, em que o narradorpersonagem, Brás Cubas, conta a sua história depois de morto. Outro exemplo desse tipo de narrador é do próprio Machado de Assis, em Dom Casmurro, em que o narrador-personagem, Bento Santiago, conta a história de sua vida desde a infância. A narratologia chama esse narrador de narrador autodiegético ${ }^{12}$.

Na segunda possibilidade, o narrador conta uma história da qual é uma testemunha. De acordo com Leite,

ele narra em 1 a pessoa, mas é um "eu" já interno à narrativa, que vive os acontecimentos aí descritos como personagem secundária

12 Genette (op. cit.) cunha os termos "narrador autodiegético", "homodiegético" e "heterodiegético". 
que pode observar, desde dentro, os acontecimentos, e, portanto, dá-los ao leitor de modo mais direto, mais verossímil. (LEITE, 2005, p. 37)

A narratologia amplia esse conceito por denominá-lo narrador homodiegético. Segundo Reis e Lopes, seu destaque "pode ir da posição de simples testemunha imparcial a personagem secundária estreitamente solidária com a central" (REIS \& LOPES, 2002, p. 124). Um exemplo bastante conhecido do uso desse tipo de narrador é o narrador das histórias de Sherlock Holmes, o célebre detetive das histórias policiais do escritor inglês Arthur Conan Doyle (1859-1930). O protagonista das histórias é o detetive, mas os acontecimentos são narrados pelo personagem Watson, um médico amigo de Holmes. O ponto de vista é sempre o de Watson, uma testemunha ocular dos acontecimentos que envolvem seu melhor amigo.

Na narratologia, o narrador de $3^{a}$ pessoa é denominado de narrador heterodiegético, termo que procura abarcar as especificidades que vamos rever a seguir. De acordo com Reis e Lopes, o narrador "relata uma história à qual é estranho, uma vez que não integra nem integrou, como personagem, o universo diegético em questão". (REIS \& LOPES, 2002, p. 121).

Em estudo sobre a narrativa, Pires (1980, p. 130) entende que o narrador em $3^{a}$ pessoa pode ser "limitado, testemunhal ou onisciente".

O narrador-observador pode ser limitado ou testemunhal (visual). O narrador é limitado quando o seu conhecimento "se limita ao de um personagem e às circunstâncias de sua vida e de suas ações". É o caso do narrador de $O$ alienista, por exemplo. $O$ narrador se limita à vida de Simão Bacamarte, o protagonista, mas não penetra no âmago dos sentimentos e angústias do personagem. $O$ narrador é testemunhal quando constitui um expectador neutro, um "mero observador dos acontecimentos que narra, os quais falarão por si ao leitor". Como exemplo, o autor cita os contos de Guy de Maupassant. 
Outro narrador de $3^{a}$ pessoa é o narrador onisciente. Pires o descreve como alguém que "sabe tudo a respeito dos acontecimentos e dos personagens, conhecendo destes os pensamentos, as intenções, toda a vida interior". Um exemplo notável desse tipo de narrador é o narrador de Vidas Secas, de Graciliano Ramos. Os sentimentos mais íntimos das personagens são desnudados pelo narrador.

Para este trabalho nos importa o primeiro tipo de narrador, isto é, o narrador autodiegético ou narrador-protagonista.

Quarto de despejo é uma narrativa autodiegética, isto é, uma narrativa em $1^{\text {a }}$ pessoa na qual a narradora relata as próprias experiências como personagem central (ou protagonista) da história.

Em um relato autobiográfico como Quarto de despejo diferentemente de uma obra ficcional narrada em primeira pessoa - a narrativa traz ao leitor o relato do quotidiano de pessoas reais. A narradora-protagonista de Quarto de despejo é uma mulher pobre, que mora em um barraco com três filhos e retira do lixo o material reciclável de sua sobrevivência, latas e papel.

Um dos recursos mais presentes na narrativa de Quarto de despejo é o que Carvalho chama de "primeira pessoa interpretativa", em que "o narrador comenta os fatos, ou os deforma, imprimindo-Ihes conscientemente um colorido subjetivo" (CARVALHO, 2012, p. 53). Não podemos afirmar que a narradora deforme os fatos, mas ela não se limita a narrar os acontecimentos. Tece comentários e lhes imprime esse "colorido subjetivo". Se bem que em Quarto de despejo essa noção de "colorido" talvez não fosse o termo mais adequado, tendo em vista a atmosfera escura que o contexto social da favela imprime aos acontecimentos.

Há momentos em que a narradora se afasta brevemente do que relata e faz digressões. Na seguinte entrada, de 14 de junho de 1958, relata que ouviu uma mulher reclamar da falta de comida. E diz: 
14 de junho de 1958 (...) Fiquei nervosa ouvindo a mulher lamentar-se porque é duro a gente vir ao mundo e não poder nem comer. Pelo que observo, Deus é o rei dos sábios. Ele pois os homens e os animais no mundo. Mas os animais quem lhes alimenta é a Natureza porque se os animais fossem alimentados igual os homens, havia de sofrer muito. Eu penso isto, porque quando eu não tenho nada para comer, invejo os animais. (p. 61, linhas 26-32)

Embora relate o que ocorre a outra pessoa, a narradora também se coloca na narrativa por fazer reflexões existenciais.

Em outros momentos, a narradora relata acontecimentos nos quais não toma parte, expressando por vezes juízos de valor sobre as ações de outrem. É o que vemos na entrada de 8 de junho de 1958:

8 de junho de 1958 (...) Na enchente de 49 morreu o Pedro Cardoso, filho de Dona Ida. Quando eu soube que o Pedrinho havia morrido afogado pensei na decepção que teve a sua avó que pedia água, água, bastante água para matar os favelados e veio água e matou- Ihe o neto. (p. 57, linhas 24-28)

Na maior parte dos acontecimentos de Quarto de despejo, porém, a narradora está envolvida como protagonista em interação com outros da favela ou de fora dela. No trecho a seguir, na entrada de 16 de julho, vemos a narradora relatando uma ação habitual, em que os personagens são Carolina e os filhos:

16 de julho de 1955 (...) Cheguei em casa, fiz o almoço para os dois meninos. Arroz, feijão e carne. E vou sair para catar papel. Deixei as crianças recomendei-lhes para brincar no quintal e não sair na rua, porque os péssimos vizinhos que eu tenho não dão sossego aos meus filhos. Saí indisposta, com vontade de deitar. (p. 14, linhas 12-17)

Essa estruturação é predominante no texto e aparece quando a narradora relata acontecimentos nos quais tomou parte. No exemplo em questão, relata sua volta para casa, onde dá comida aos filhos, dá-Ihes instruções de comportamento e retorna à rua para recolher papel.

\section{2 - Os personagens}

Os personagens são figuras que "representam pessoas, segundo 
modalidades próprias da ficção" (BRAIT, 2009, p. 11). Pires afirma que "a criatura ficcional é, normalmente, imitação do ser humano" (PIRES, 1981, p. 117).

Se em uma ficção propriamente dita o personagem é uma entidade que não existe materialmente, em Quarto de despejo os personagens são as pessoas que vivem na favela ou nas suas proximidades.

Cada um desempenha uma função narrativa, isto é, papéis resultantes da ação; o narrador autodiegético é o protagonista dos acontecimentos: é ele quem vê o que acontece na favela, quem relata seu quotidiano e seus conflitos com outros personagens (antagonistas).

Constituem personagens somente pessoas que desempenham função no desenrolar dos acontecimentos. Embora Quarto de despejo cite Adhemar de Barros, Juscelino Kubistchek e Carlos Lacerda, por exemplo, eles não são personagens da obra porque não fazem parte de nenhum relato em particular, não executam nenhuma ação propriamente dita, sendo apenas mencionados pela narradora.

As ações dos personagens representam funções narrativas definidas: o protagonista é um agente-vítima, não só dos conflitos com outros personagens, com também da pobreza e da miséria, condições sobre as quais não dispõe de controle.

A partir das reflexões de Pires (1981, p. 118-119), três funções básicas das personagens podem ser vistas em Quarto de despejo:

a) Protagonista - "É o Herói, o Sujeito, o personagem principal; ocupa o lugar de maior destaque no desenrolar dos acontecimentos".

Carolina, a narradora-personagem, é a protagonista dos acontecimentos narrados em Quarto de despejo, relato de suas agruras existenciais. Ainda que em alguns momentos focalize personagens secundários, sua presença continua marcante no plano da narrativa.

b) Antagonista - "É o Vilão da estória, aquele que se opõe e contesta 
o protagonista; pode ser uma pessoa ou forças antagônicas (internas e externas) ao indivíduo".

No decorrer da narrativa, embora não haja uma única história, mas pequenos flashes cotidianos, alguns moradores da favela, em marcante hostilidade em relação à Carolina, constituem antagonistas em vários momentos, conforme veremos no exemplo a seguir:

25 de junho de 1959 ...Voltei para o meu barraco imundo. Olhava o meu barraco envelhecido. As tábuas negras e podres. Pensei: está igual a minha vida!

Quando eu preparava para escrever, o tal Orlando surgiu e disse que queria o dinheiro. Dei-lhe 100 cruzeiros.

- Eu quero 250. Quero o depósito.

- Eu não pago depósito porque já foi abolido pela Light.

- Então eu corto a luz.

E desligou-a. (p. 167, linhas 24-33)

$\mathrm{Na}$ passagem em questão, há um diálogo áspero entre a protagonista, enquanto personagem, e outro morador da favela, chamado Orlando, que aparece na narrativa como seu antípoda.

c) Confidente - "Relaciona-se diretamente com o personagem principal, ouvindo seus depoimentos, fazendo-lhe perguntas cujas respostas, muita vez, tornam mais claros seus planos ou suas ideias".

Os filhos de Carolina são os seus confidentes, pois não apenas estão mais próximos como também interagem com mãe, fazem perguntas e comentários que se relacionam à temática da narração.

d) Secundários - "São os participantes dos acontecimentos sem terem projeção na intriga".

Em Quarto de despejo, algumas personagens aparecem de relance e não têm sequer um nome, como na seguinte entrada, de 13 de junho de 1958:

13 de junho de 1958 ...Vesti as crianças e eles foram para a escola. Eu fui catar papel. No Frigorífico vi uma mocinha comendo salsichas do lixo.

- Você pode arranjar um emprego e levar uma vida reajustada. 
Ela perguntou-me se catar papel ganha dinheiro. Afirmei que sim. Ela disse-me que quer um serviço para andar bem bonita. Ela está com 15 anos. Época em que achamos o mundo maravilhoso." (p. 60, linhas 12-20)

A narradora relata um momento de conversa com uma pessoa desconhecida, uma mocinha, cujo nome provavelmente desconhece. Frequentemente, porém, os personagens aparecem diversas vezes, ou seja, Carolina, os filhos, os moradores da favela, do seu entorno ou comerciantes.

Os personagens, em sua maioria, são secundários, ou seja, não possuem papel de relevo na narrativa, mas alguns, citados mais de uma vez, como Orlando e Leila, por exemplo, são suas antagonistas.

\section{3 - Tempo e Espaço}

O tempo da narrativa é a representação do tempo cronológico, isto é, "o tempo matemático propriamente dito, sucessão cronológica de eventos suscetíveis de serem datados com maior ou menor rigor" (REIS \& LOPES, 2002, p. 220). O relato é relativamente cronometrado, e pela natureza do texto o tempo é fundamental.

Por se tratar de um diário, isto é, de uma narrativa com datas específicas, a narradora conta linearmente o que acontece todos os dias. Quando dissemos "relativamente cronometrado", nos reportamos ao fato de que o tempo não é absolutamente cronometrado, pois os acontecimentos diários aparecem sem especificidade de duração. Vejamos o seguinte exemplo, da entrada de 9 de agosto de 1958:

9 de agosto de 1958 Deixei o leito furiosa. Com vontade de quebrar e destruir tudo. Porque eu tinha só feijão e sal e amanhã é domingo. (p. 105, linhas 25-27).

No segmento acima, relata a ação habitual de acordar e deixar a cama, mas não diz o horário. Só temos a indicação de data, 9 de agosto de 1958, e que se trata de um sábado. Mas esses elementos não se fazem necessários para o que se conta. 
O que é relevante apontarmos, na questão temporal, é que o tempo, em certa medida, é sufocante: os dias vão sucedendo, com ações habituais e repetidas, sem perspectiva de uma mudança na vida da Carolina e de sua família.

Intimamente ligado ao tempo, em Quarto de despejo o espaço é fundamental. De acordo com Reis e Lopes,

entendido como domínio específico da história, o espaço integra,
em primeira instância, os componentes físicos que servem de
cenário ao desenrolar da ação e à movimentação das
personagens: cenários geográficos, interiores, decorações, objetos
etc; em segunda instância, o conceito de espaço pode ser
entendido em sentido translato, abarcando tanto as atmosferas
sociais como até as psicológicas. (REIS \& LOPES, 2002, p. 204)

Assim como o tempo, o espaço possui um sentido importante e condutor da narrativa de Quarto de despejo: a narrativa se passa na favela; embora não haja um enredo ${ }^{13}$ propriamente dito, o espaço dos acontecimentos é o palco no qual a pobreza e seus dramas resultantes regem os acontecimentos e exercem impacto sobre a linguagem da narradora: a gíria, os vocábulos de uso injurioso, vulgar e obsceno são reflexos do ambiente onde acontecem os fatos.

\section{4 - Conflito}

Há em Quarto de despejo uma sucessão de vários conflitos. Assinalamos no plural porque não se trata de um único conflito, gerador de uma história, mas de conflitos diários, pequenas narrativas cotidianas inseridas em uma narrativa maior cujo objetivo é testemunhar tudo o que acontece à sua volta.

Cada entrada do diário introduz um novo conflito a cada dia, seja a luta do protagonista pela sobrevivência, suas controvérsias com outros personagens ou as controvérsias de outrem. Ressalvamos que, ao falarmos em conflito, pensamos não apenas em brigas e relatos violentos, 
mas também em divergências, mesmo aparentemente irrelevantes.

O seguinte trecho, da entrada de 17 de julho de 1955, traz o relato de um conflito entre a protagonista e uma vizinha.

17 de julho de 1955 (...) Fui torcer as minhas roupas. A D. Aparecida perguntou-me:

- A senhora está grávida?

- Não senhora - respondi gentilmente.

E lhe chinguei interiomente. Se estou grávida não é da sua conta. Tenho pavor destas mulheres da favela. Tudo quer saber! A língua delas é como os pés de galinha. Tudo espalha. Está circulando rumor que eu estou grávida! E eu, não sabia! ( $p$. 15, linhas 23-31)

Reparamos um pequeno conflito: uma personagem faz uma pergunta que ofende a narradora, cujo relato culmina com uma reflexão desabonadora sobre o caráter das mulheres da favela.

A narradora inicia sua explanação dizendo que ia torcer suas roupas e culmina em uma reflexão sobre o caráter das suas vizinhas.

No trecho a seguir, da entrada de 18 de julho de 1955, reporta-se a uma discussão acalorada com uma personagem chamada Sílvia. Lemos o seguinte:

18 de julho de 1955 (...) A Sílvia pediu-me para retirar o seu nome do meu livro. Ela disse:

Você é mesmo uma vagabunda. Dormia no Albergue Noturno. O seu fim era acabar na maloca.

Eu disse:

- Está certo. Quem dorme no Albergue Noturno são os indigentes. Não tem recurso e o fim é mesmo nas malocas, e você, que diz nunca ter dormido no Albergue Noturno, o que veio fazer aqui na maloca? Você era para estar residindo numa casa própria. Por que a sua vida rodou igual a minha?

Ela disse:

- A única coisa que você sabe fazer é catar papel.

Eu disse:

- Cato papel. Estou provando como vivo! (p. 21, linhas 16-29)

Os conflitos entre as personagens desencadearão o uso de diversos 
vocábulos de cunho injurioso em diversos pontos da narrativa.

2.5 - O discurso direto, indireto e indireto-livre: a representação das vozes no discurso

Faz-se necessário, antes de prosseguirmos com as nossas reflexões, esclarecer o sentido de discurso que adotamos neste trabalho. Como propõe Oesterreicher,

el concepto de discurso es relativamente fácil de entender. Discurso es simplemente sinónimo de enunciado o secuencia de enunciados y corresponde, dicho sea de paso, a lo que en linguística textual se suele calificar de texto. Es decir, una conversación familiar, una llamada telefónica, pero tambíen una carta, un artículo de fondo, un documento jurídico etc - todas estas formas de la comunicación verbal representan discursos. Conforme a este empleo del término, tenemos que entender por discurso toda manifestación concreta de la actividad del hablar según las reglas de una determinada lengua, concebida esta última como técnica histórica del hablar. (OESTERREICHER, 1997, p. 86, grifos do autor) ${ }^{14}$

Não fazemos coro ao autor quando afirma que "o conceito de discurso é relativamente fácil de entender", pois "discurso" é um termo polissêmico, contemplado por enfoques diversos; entretanto, em consonância com seu pensamento, aqui compreenderemos discurso como toda manifestação concreta da linguagem, como a atividade verbal em ação.

De acordo com Garcia,

ao transmitir pensamento expresso por personagem real ou imaginária, o narrador pode servir-se do discurso direto ou do indireto, e, às vezes, de uma contaminação de ambos - 0

14 "O conceito de discurso é relativamente fácil de entender. Discurso é simplesmente sinônimo de enunciado ou sequência de enunciados e corresponde, aliás, ao que em linguística textual costuma-se chamar de texto. Ou seja, uma conversação familiar, uma chamada telefônica, mas também uma carta, un artigo, un documento jurídico etc todas estas formas da comunicação verbal representam discursos. Conforme este emprego do termo, temos que entender por discurso toda manifestação concreta da atividade do falar segundo as regras de uma determinada língua, concebida esta última como técnica histórica do falar." 
chamado discurso indireto-livre ou misto ou semi-indireto (GARCIA, 1997, p. 129)

Assim, quando nos referimos narrativa de Quarto de despejo, é importante termos em vista o processo de representação das falas, como a narradora incorpora sua própria fala como personagem e a fala de outrem. A principal maneira de incorporação da fala (ou voz) é a citação. As principais maneiras de citação são o discurso direto e o discurso indireto, ambas presentes na organização textual.

\subsection{1 - O discurso direto}

O discurso direto é a citação integral da fala do personagem, da exata maneira como a enuncia, isto é, o personagem fala diretamente, tendo sua fala introduzida pelo narrador.

A maneira mais convencional é por meio do emprego de verbos dicendi (ou verbos de elocução, tais como dizer, falar, perguntar, responder etc), de travessões e de dois pontos, como na passagem a seguir, de 22 de maio de 1958, na qual a narradora, ao relatar a falta de comida, introduz uma fala da filha:

22 de maio de 1958 (...) O dinheiro não deu para comprar carne, eu fiz macarrão com cenoura. Não tinha gordura, ficou horrível. A Vera é a única que reclama e pede mais. E pede:

- Mamãe, vende eu para a Dona Julita, porque lá tem comida gostosa. (p. 42, linhas 21-25)

No exemplo acima, o verbo pedir funciona como um verbo dicendi pois serve para introduzir diretamente a fala da personagem, sendo seguido de dois pontos e com o travessão na linha seguinte reproduzindo a fala da personagem.

\subsection{2 - O discurso indireto}


Outra maneira de se fazer citação é por meio do discurso indireto, que é o registro da fala do personagem por intermédio do narrador. A fala do personagem é incorporada ao discurso do narrador, que a introduz com suas próprias palavras.

No registro de 4 de janeiro de 1959, fala de um vizinho que tem problemas de saúde. A fala desse vizinho é reproduzida por meio de discurso indireto:

4 de janeiro de 1959 (...) O Ireno é um coitado que está com anemia. Procura a esposa. A esposa não the quer. Ele disse-me que a sua sogra instiga a esposa contra ele. Agora ele está na casa do irmão. Ele foi passar uns dias na casa da irmã. Retornou-se. Disse-me que lhe jogavam indiretas por causa da comida.

O Ireno disse que já está descontente da vida. Porque a vida com saúde já é tão pungente... (p. 144, linhas 5-11)

Na passagem em questão, o discurso indireto deixa visíveis marcas de elaboração linguística. Nenhuma narrativa é absolutamente confiável, no sentido de que os acontecimentos tenham ocorrido da maneira exata, ou que os personagens tenham falado exatamente o que está registrado que falaram.

No discurso direto há uma maior aparência de realidade porque as falas são citadas diretamente, sem intervenção do narrador. No discurso indireto, porém, o narrador põe as palavras na boca do personagem, citando-as como se fossem dele, porém o faz indiretamente.

Terá o personagem falado exatamente daquela maneira? No exemplo citado, teria o morador da favela usado o verbo "instigar" ou o adjetivo "pungente"? Quase certo que não, visto que não condizem com a condição sociocultural das outras personagens, exceto a própria narradora. Talvez tenha usado o primeiro vocábulo, "instigar", mas dificilmente teria dito "pungente", que parece ser uma interpretação do narrador, sua impressão do que acontece com a personagem.

\subsection{3 - O discurso indireto-livre}


Em vários momentos, a narradora reproduz uma fala interior, o seu pensamento, enquanto, no papel de protagonista, interage com outros personagens. Vemos isto na seguinte entrada, de 17 de julho de 1955, já citada anteriormente (em 1.3.4), quando relata seu diálogo com outra moradora da favela:

17 de julho de 1955 (...) Fui torcer as minhas roupas. A D. Aparecida perguntoume:

- A senhora está grávida?

- Não senhora - respondi gentilmente.

E lhe chinguei interiomente. Se estou grávida não é da sua conta. (p. 15, linhas 23-27)

$\mathrm{Na}$ passagem em questão, a narradora reproduz uma fala interior, embora não use aspas nem travessões.

2.6 Alinhavando as ideias

Embora este não seja um trabalho de teoria literária, mas de análise linguística, acreditamos que essa questão "estrutural" da narrativa seja útil para compreendermos a organização do texto de Carolina, bem como o contexto de uso do léxico.

Considerando Quarto de despejo uma narrativa e, desse modo, um texto que apresenta os componentes da narração, ter em vista esses mecanismos de construção nos parece útil para a compreensão dos usos vocabulares da narradora.

E sobre a questão do léxico propriamente dito, cabe ainda pôr em revista alguns tópicos sobre a formação e a constituição do léxico, tema de nosso próximo capítulo. 


\section{CAPÍTULO 3 - FORMAÇÃO E CONSTITUIÇÃO DO LÉXICO}

Por que estudar o léxico? Um estudo dessa natureza começa por levantar a pergunta óbvia: o que é léxico? Para nós, mais do que conceituá-lo e compreender sua estrutura, como estudá-lo sob a perspectiva da oralidade? Por que um estudo dessa natureza oferece dificuldades? Que dificuldades são essas? Quando por vezes nos reportamos a "léxico" ou "vocabulário", estamos falando de conceitos indistintos?

O estudo do léxico sempre despertou o fascínio dos estudiosos. De acordo com Auroux, na Antiguidade o estudo da linguagem tem início com a organização de listas de vocábulos:

O que aparece em primeiro lugar são listas de palavras (ou de
caracteres, para o chineses). Sua utilização não é muito clara no
início; elas têm talvez um papel mnemotécnico e, no caso dos
silabários, serviram provavelmente para a aprendizagem da
escrita. (...) Entre os babilônios encontramos igualmente listas de
palavras, três milênios antes de nossa era. Entre os gregos,
Protágoras de Abdere compila, no quinto século antes de nossa
era, um léxico de palavras difíceis que encontramos em Homero.
(...) São, de algum modo, a filologia e a lexicologia que aparecem
inicialmente. (AUROUX, 1992, p. 22-23)

Se as palavras despertaram a curiosidade dos antigos, que as estudaram da forma mencionada por Auroux, para nós hoje não é diferente. Podemos dizer que a palavra é a matéria-prima da enunciação, e para uma autora como Carolina Maria de Jesus a palavra desperta um sentimento de contemplação, de fascínio pelas suas possibilidades, o que nos cabe investigar.

Como afirmou Martinet, "é, com efeito, o léxico que, numa língua, reflete mais diretamente as realidades não linguísticas". (MARTINET, apud PRETI, 2010, p. 79) Daí o desafio de um estudo dessa natureza.

Em primeiro lugar, faz-se necessário a conceituação inequívoca do que é exatamente o léxico de uma língua, como, em nosso caso, o Português. Segundo Vilela, 
por léxico duma língua poder-se-á entender o dicionário no duplo sentido de conjunto de palavras dessa língua e a sua inventariação (dicionarística ou lexicográfica), a competência lexical do falante/ouvinte nativo duma língua e, na perspectiva resultante da função representativa da linguagem, o conjunto das unidades léxicas $(=$ as unidades que representam a realidade extralinguística) duma língua. O léxico é, em primeiro lugar, entendido como o conjunto de unidades linguísticas básicas (morfemas, palavras e locuções) próprias duma língua. (VILELA, 1979, p. 9)

Trata-se de um conceito impreciso e um tanto circular, mas nos aponta alguns caminhos.

O léxico, numa primeira acepção, é o dicionário, tanto no sentido da reunião dos vocábulos de uma língua quanto na sua materialização em livro.

Numa segunda acepção, léxico é a competência lexical de um falante, isto é, o repertório vocabular do falante de uma determinada língua. Nesse sentido, não seria impróprio falarmos em um "léxico de Quarto de despejo", pois nos reportaríamos ao conjunto de vocábulos empregados na obra.

Numa terceira acepção, que se liga com a primeira, léxico é o conjunto real e potencial de todas as palavras de uma língua; impossível, portanto, de ser abarcado em sua totalidade por um compêndio lexicográfico.

Esse eixo tríplice de compreensão do léxico pode assim ser sintetizado:

Tabela 02 - Concepções de Léxico

LÉXICO

(inventário aberto)

falante 
Esta dissertação focalizará a segunda acepção, ou seja, o léxico como competência lexical de um usuário (ou falante) da língua, ainda que a terceira acepção não esteja totalmente fora de questão, visto que ambas estão, de certa forma, interligadas. Novamente recorremos a Vilela:

Compreendemos o léxico como a totalidade das palavras duma língua, ou, como o saber interiorizado, por parte dos falantes de uma comunidade linguística, acerca das propriedades lexicais das palavras (propriedades fonético-fonológico-gráficas, propriedades sintáticas e semânticas. (VILELA, 1994, p. 10, grifo nosso)

Quando falarmos em "léxico" estaremos, num primeiro momento, fazendo referência ao universo vocabular da narradora de Quarto de despejo, objeto central deste estudo.

\section{1 - A lexia}

O repertório vocabular de um falante é formado a partir de um leque infinito de possibilidades que o sistema linguístico oferece. Esse repertório constitui-se de um número infinito de unidades, chamadas normalmente de "palavras" ou "vocábulos". Ressalte-se que, embora virtualmente infinito, o falante fará uso de um número relativamente limitado, tendo em vista a impossibilidade e desnecessidade de um uso total.

Segundo Biderman, "termos como palavra e vocábulo da linguagem comum se prestam a equívocos e imprecisões. Por esta razão, os linguistas cunharam o termo lexema para designar a unidade léxica abstrata em língua". (BIDERMAN, 2001, p. 169)

A unidade do léxico, chamada de lexia por Pottier, Audubert e Pais, é definida como "a unidade lexical memorizada". (POTTIER, AUDUBERT \& PAIS, 1972, p. 26). De acordo com os autores,

o locutor, quando diz "quebrar o galho", "Nossa Senhora!", "pelo amor de Deus", "bater as botas", "barra limpa", "nota promissória", não constrói essa combinação no momento em que fala, mas tira o conjunto de sua "memória lexical", da mesma forma que "banco", "livro". (POTTIER, AUDUBERT \& PAIS, 1972, p. 26-27)

Os autores distinguem quatro tipos de lexia, a saber, "lexia simples", 
"lexia composta", "lexia complexa estável" e "lexia textual".

\subsection{1 - A lexia simples}

A lexia simples, assim como o próprio nome sugere, é formada por uma só base ou, de acordo com Biderman, trata-se de "unidades que são grafadas como um único segmento" (BIDERMAN, 2001, p. 172). Ex: livro.

\subsection{2 - A lexia composta}

A lexia composta é formada por duas ou mais bases, unidas ou não por hífen. A lexia composta aparece na formação de substantivos ou de adjetivos. Exemplo: bate-estaca.

\subsection{3 - A lexia complexa estável}

A lexia complexa estável apresenta difícil conceituação, podendo ser confundida com a lexia composta.

De acordo com Biderman, são "sintagmas lexicalizados", entre os quais "um número grande de expressões idiomáticas ou idiotismos na terminologia da gramática tradicional". Tais idiotismos

$$
\begin{aligned}
& \text { são combinatórias de lexemas que o uso consagrou numa } \\
& \text { determinada sequência e cujo significado não é a somatória das } \\
& \text { suas partes. Nesses casos, não se pode chegar ao significado da } \\
& \text { expressão completa, somando-se os significados de cada um dos } \\
& \text { seus elementos constituintes. Esse tipo de sintagma léxico é } \\
& \text { indecomponível e, frequentemente, possui uma significação } \\
& \text { metafórica". (BIDERMAN, 2001, p. 172-173, grifo nosso) }
\end{aligned}
$$

São lexias complexas não só lexemas como "Papai Noel", "primeiro de abril" ou "lentes de contato", como também palavras gramaticais, tais como algumas conjunções e locuções adverbiais, como "por mais que", "ao passo que", "se bem que" etc. (Biderman, op. cit., p. 175) 
Os idiomatismos (ou expressões idiomáticas) são exemplos de lexias complexas, visto não poderem ser decompostos em unidades menores sem prejuízo de sentido. Nem todas as lexias complexas, porém, são expressões idiomáticas, visto que muitas constituem palavras gramaticais, distinção igualmente importante para este trabalho, a que aludiremos mais adiante.

\subsection{4 - A lexia textual}

Também de difícil conceituação, a lexia textual de certa forma pode ser confundida com a lexia complexa, visto também envolver um conjunto de unidades em um todo significativo.

O que parece ser um traço distintivo é que a lexia textual constitui uma sentença com valor lexical. Pottier, Audubert e Pais citam como exemplo "quem tudo quer tudo perde". (POTTIER, AUDUBERT \& PAIS, 1972, p. 26).

As frases feitas e os provérbios são exemplos de lexias textuais. Podemos citar o seguinte exemplo de lexia textual em Quarto de despejo:

27 de junho de 1959 ... 0 tal Orlando Lopes passava de bicicleta. Os meus filhos falaram

- Olha o Orlando!

Eu disse-lhes:

Eu não vou falar com esse nojento.

Ele ouviu e respondeu:

- Nojento é a puta que te pariu. (p. 168)

O segmento em negrito, "é a puta que te pariu" constitui uma frase feita de uso injurioso e obsceno, típica da língua falada popular.

Simples, compostas, complexas ou textuais, nem todas as lexias desempenham o mesmo papel dentro de um enunciado, tema de nosso próximo tópico. 
3.2 - Palavras lexicais e palavras gramaticais

A este trabalho interessam apenas as chamadas palavras lexicais, ou seja, aquelas que traduzem uma realidade extralinguística, que despertam uma representação mental ou imagética.

São também chamadas de palavras lexicográficas, nocionais, reais ou plenas (MARTINS, 2000, P. 77). Tais lexias possuem uma significação externa, ao contrário das palavras gramaticais, esvaziadas de sentido e com significação interna. As palavras gramaticais também são chamadas de palavras-formas, palavras vazias e instrumentos gramaticais (MARTINS, 2000, p. 72).

Vejamos o seguinte exemplo de Quarto de despejo:

22 de maio de 1958 (...) O dinheiro não deu para comprar carne, eu fiz macarrão com cenoura. Não tinha gordura, ficou horrível. A Vera é a única que reclama e pede mais. E pede:

- Mamãe, vende eu para a Dona Julita, porque lá tem comida gostosa. (p. 42)

No segmento em questão, o hipocorístico ${ }^{15}$ "mamãe" é formado a partir do substantivo "mãe", por duplicação silábica. O substantivo "mãe", comum e concreto, possui uma imagem extralinguística e evoca uma representação mental. Quando, na voz de uma criança, assume a forma hipocorística, torna-se um vocábulo altamente expressivo e sugestivo, denotando afetividade e familiaridade. Por isso, mamãe é uma palavra lexical ou nocional e possui significação mesmo se fosse tomada isoladamente fora de um contexto.

Por outro lado, a conjunção porque introduz uma oração adverbial e sua função é meramente gramatical, constituindo um elemento coesivo. Tanto dentro do texto quanto isolada, a palavra "porque" não traduz uma imagem, não sugere nenhuma representação mental. Por isso é uma palavra gramatical.

15 Sobre hipocorísticos, cf. 4.5.7, p. 
Nosso objetivo não é analisar palavras gramaticais. Por isso, as unidades gramaticais ficam fora do nosso estudo. Não que não possam ter, em tese, valor expressivo, mas o nosso foco serão as unidades lexicais, em particular aquelas de feição popular, típicas da língua falada.

\section{3 - Campos semânticos}

No contexto de um enunciado, as lexias jamais têm significação isolada. As escolhas lexicais operadas por um enunciador sempre estarão interligadas entre si, formando uma rede maior de significados.

Por meio de sua significação, as lexias distinguem-se das demais e formam um todo com outras que possuem o mesmo referencial (ou os mesmos traços), formando uma família de palavras.

A esse conjunto de lexias que, dentro de um contexto, estão interligados em termos de significação se dá o nome de "campo semântico".

Essa interligação é assim caracterizada pelas autoras portuguesas Lopes e Rio-Torto: um campo léxico-semântico compreende lexias da mesma classe
sintática de palavras (substantivo, adjetivo, verbo), que tem
significações comuns e que estão inter-relacionadas entre si por
nexos de significação perfeitamente determináveis. (LOPES \& RIO-
TORTO apud CARDOSO, 2013, p. 19)

Em Quarto de despejo, a pobreza, a favela, a violência, os estereótipos raciais e o sexo são tematizados por uma expressiva gama de lexemas que conferem à narrativa, apesar de fragmentária, uma surpreendente coerência temática.

Tomemos o seguinte exemplo da entrada de 22 de maio de 1958:

22 de maio de 1958 (...) Eu sei que existe brasileiros aqui dentro de São Paulo que sofre mais do que eu. Em junho de 1957, eu fiquei doente e percorri as sedes do Serviço Social. Devido eu carregar muito ferro fiquei com dor nos rins. Para não ver os meus filhos passar fome, fui pedir auxílio ao propalado Serviço Social. Foi lá que eu vi as 
lágrimas deslizar dos olhos dos pobres. Como é pungente ver os dramas que ali se desenrola. A ironia com que são tratados os pobres. A única coisa que eles querem saber são os nomes e os endereços dos pobres. (p. 42, linhas 26-35)

Podemos notar ao longo do parágrafo como a pobreza e a miséria são caracterizadas por vários vocábulos interligados semanticamente entre si, constituindo, no exemplo, um campo semântico de "pobreza" e "miséria".

Os vocábulos possuem traços negativos. Há ocorrência de três lexias verbais que caracterizam a vida difícil: sofrer, carregar ferro, passar fome (no contexto, uma lexia complexa). Dois adjetivos também possuem a mesma carga semântica: doente e pungente. Entre os substantivos, pobre aparece três vezes, bem como lágrimas, dor (nos rins) e dramas.

Essa interligação pode ser visualizada na tabela que segue:

Tabela 03 - Modelo de Campo Semântico

\begin{tabular}{|c|c|c|}
\hline \multicolumn{3}{|c|}{ POBREZA É SOFRIMENTO } \\
\hline Verbos & Adjetivos & Substantivos \\
\hline $\begin{array}{c}\text { sofrer } \\
\text { carregar (ferro) } \\
\text { passar fome }\end{array}$ & doente & lágrimas \\
& pungente & $\begin{array}{c}\text { pobres (três vezes) } \\
\text { dor (nos rins) } \\
\text { dramas }\end{array}$ \\
\hline
\end{tabular}

Se contarmos independentemente as três ocorrências de "pobres", temos, em um parágrafo de apenas 10 linhas, 11 vocábulos de traço semântico negativo que caracterizam a vida difícil dos protagonistas da vida da favela, os "brasileiros aqui dentro de São Paulo".

O universo vocabular de Quarto de despejo é marcado por traços de língua falada, corporificados por itens lexicais de uso popular, informal ou afetivo. 
De acordo com Bally, o ato comunicativo não se limita à transmissão de uma mensagem, mas envolve, por parte dos falantes de uma língua, a expressão dos estados emocionais. Na realidade, esse aspecto da língua, a expressividade, "precede o verbal cognitivo" (URBANO, 2005, p. 115). Não apenas precede, como também implica a projeção de sentimentos no interlocutor.

Embora não estejamos, conforme explicitado anteriormente, analisando um corpus de língua falada, as reflexões de Bally, que contemplaram a língua falada, também nortearão nossa análise, visto que nosso corpus é constituído de um texto escrito com marcante influência da língua falada. Para Bally,

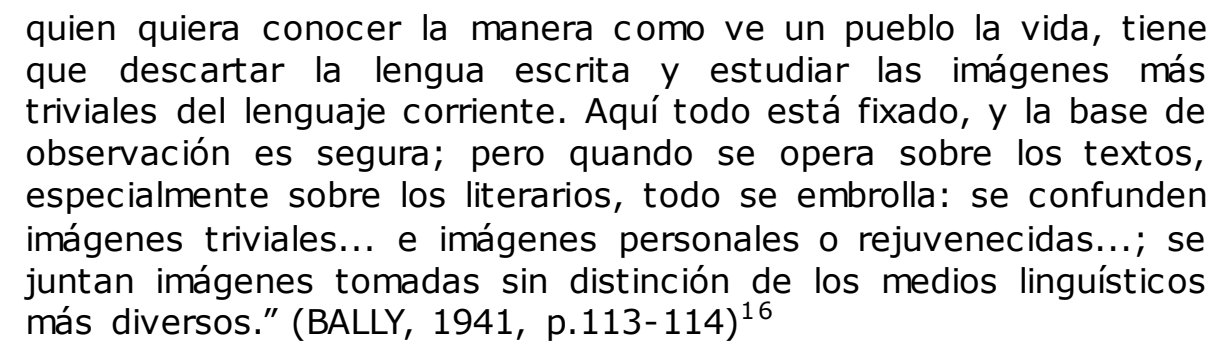

O mestre francês vislumbrou uma perspectiva nova para seu tempo e que esclarece muitos fatos de linguagem: a expressividade não está só no texto escrito, especialmente no literário, ou na língua culta (quer na sua expressão escrita, quer falada). A expressividade se evidencia em todo ato enunciativo, em maior ou menor grau.

O enunciador jamais é neutro ou apático: todo ato de linguagem é dialógico e pressupõe um remetente ou enunciatário a quem é dirigido. Alguns temas ou tipos de texto podem envolver particularidades que suscitem emotividade. Ainda de acordo com Bally,

16 "Quem quiser conhecer o modo como um povo vê a vida tem que pôr de lado a língua escrita e estudar as imagens mais triviais da linguagem comum. Aqui tudo está fixado, e a base de observação é segura; mas quando se opera sobre textos, especialmente sobre os literários, tudo se torna indistinto: confundem-se imagens triviais... e imagens pessoais ou renovadas...; juntam-se imagens tomadas sem distinção dos meios linguísticos mais diversos." 
la afectividad es la manifestación natural y espontanea de las formas subjetivas de nuestro pensamiento: está indisolublemente ligada a nuestras sensaciones vitais... sera expressivo todo hecho de linguaje asociado a una emoción. (BALLY, 1941, p. 123) ${ }^{17}$

Veremos adiante, ao analisarmos Quarto de despejo detidamente, que as escolhas lexicais de Carolina apresentam um intenso componente expressivo. Qualquer texto - literário ou não - pode ser estilisticamente expressivo, e Quarto de despejo não é uma exceção.

As operações linguísticas não são mecânicas, não são realizadas por máquinas. São atividades humanas. Como disse Benveniste, "uma língua sem expressão da pessoa é inconcebível". (BENVENISTE, 1995, p. 287)

O emprego do léxico é, acima de tudo, uma atividade enunciativa e, como tal, não prescinde das intenções e das emoções do enunciador nem do que este pretende projetar no enunciatário. De acordo com Benveniste, "o que em geral caracteriza a enunciação é a acentuação da relação discursiva com o parceiro, seja este real ou imaginado, individual ou coletivo." (BENVENISTE, 1989, p. 87)

A enunciação de Quarto de despejo, como de qualquer outro discurso, não é uma atividade isenta de intencionalidade. Embora o diário tenha tomado fôlego depois de Carolina conhecer Audálio Dantas e ter a publicação em vista, sua atividade é bem anterior. "Real ou imaginado", existe um "parceiro" dessa atividade, um leitor potencial.

Todo ato enunciativo pressupõe a construção de uma autoimagem, e para isso não é necessário o enunciador falar de si ou colocar-se em relevo diretamente. Sua competência linguística, seu "estilo", suas crenças implícitas ou explícitas formam um todo capaz de operar os efeitos de sentido pretendidos.

A enunciação de Quarto de despejo deixa à mostra um enunciador que pretende não apenas relatar o seu quotidiano sofrido na favela, mas

17 "A afetividade é a manifestação natural e espontânea das formas subjetivas de nosso pensamento: está indissoluvelmente ligada a nossas sensações vitais... será expressivo todo fato de linguagem ligado a uma emoção." 
construir um discurso literário, efetuar uma apresentação de si por meio das palavras.

Não há, portanto, como negar a subjetividade da linguagem, isto é, a presença desse "eu" que toma a palavra e quer projetar sua presença no mundo e dialoga com um "tu". Novamente recorremos a Benveniste, para quem, "a instalação da "subjetividade" na linguagem cria na linguagem e, acreditamos, igualmente fora da linguagem, a categoria de pessoa". (BENVENISTE, 1995, p. 290)

O "eu" se instala na enunciação em função de um "tu". Esse "tu", com quem o "eu" compartilha a enunciação, é o alvo das projeções do "eu".

A subjetividade, isto é, a presença desse "eu" enunciador se manifesta em Quarto de despejo sobretudo pela sua linguagem peculiar, materializada pela permanente colisão entre um vocabulário de caráter popular e um vocabulário de feições eruditas, colhido de suas leituras e da impressão de que esse era o passaporte para um mundo letrado. Trataremos disso mais adiante. 


\section{CAPÍTULO 4 - DISCUTINDO AS RELAÇÕES ENTRE LÍNGUA FALADA E LÍNGUA ESCRITA}

4.1 - A variação linguística: entre a norma e a mudança

Dentre todas as instâncias sociais, a língua ${ }^{18}$ é certamente a mais resistente a mudanças, pois sofre os influxos de uma tradição conservadora escrita que fixou modelos considerados corretos pela comunidade.

Por ser o instrumento de interação por excelência entre os membros de uma comunidade linguística, a língua escrita constitui o principal instrumento de fixação da cultura de um povo, que se processa, principalmente, por meio dos documentos históricos e da literatura.

Socialmente há um conjunto de usos considerados modelares e dignos de preservação, fixados pela tradição, e cujo emprego, ideal para usuários que desejam ser letrados e "cultos", parece impelir para o extremo oposto outros usos não contemplados por esse modelo. A essas prescrições é que alude Aléong:

A observação do comportamento linguístico estabelece a existência
de uma distância maior ou menor entre o sistema socialmente
dominante das prescrições linguísticas e a realidade dos
desempenhos diários. Isso significa que, de um lado, um conjunto
de julgamentos de valores amplamente difundidos - uma ideologia
linguística - preconiza o emprego de certas formas com a exclusão
de outras em nome da correção linguística, ao passo que, de outro
lado, as realizações concretas se apresentam sob o aspecto de
uma notável diversidade de formas. (ALÉONG, 2001, p. 145, grifo
nosso)

Logo, espera-se que o modelo de língua seja usado quotidianamente, e a tradição exerce uma função reguladora e consolidadora do que é considerado de "bom tom"19 em matéria de linguagem, na realidade um conjunto de convenções sociais formadas ao longo do tempo. O mesmo autor reconhece essa arbitrariedade:

18 Principalmente em sua modalidade escrita.

19 Segundo Aléong, "le bon usage" (p. 145). 
Como a norma representa uma seleção dentre as formas reais ou possíveis, é preciso reconhecer a arbitrariedade linguística dessa norma. Tanto mais porque a história da norma em todas as línguas revela o quanto, de uma época para outra, seu uso - a ortografia, por exemplo - pode evoluir. Mas a norma é dominante em toda época e se impõe aos usuários concernidos com toda a força de uma lei fundada na ordem natural. (p. 153)

Se a norma é uma "seleção dentre as formas reais ou possíveis", certamente é arbitrária e, até certo ponto, questionável. Determinado padrão é considerado certo, por força de tradição, não porque seja intrinsecamente "correto" linguisticamente falando. Em termos de língua nada é absoluto, mas relativo.

Paradoxalmente, apesar das pressões da tradição escrita, um saber linguístico, mesmo transmitido por gerações após gerações, acaba por se transformar ao longo do tempo, como reflexo do uso de seus falantes. A língua, em qualquer etapa de sua história, jamais será idêntica aos estágios anteriores.

Antes de se consolidarem as mudanças, a língua sofre variações dentro de um determinado recorte temporal. Fatores como localização geográfica, grau de escolaridade, faixa etária, sexo ou estrato sociocultural implicarão diferenças no comportamento linguístico por parte dos falantes. Algumas dessas variações acabam por se difundir, adquirir alta frequência e se impor como novas formas.

Ao conjunto de diferenças de realização linguística entre os falantes de uma mesma língua dá-se o nome de "variação linguística".

A variação linguística ocorre em dois planos: no plano diacrônico e no plano sincrônico. A variação diacrônica é um fenômeno essencialmente histórico, por isso não será contemplado neste estudo, embora esteja relacionada à variação sincrônica.

A nós interessa o conjunto das variações sincrônicas, isto é, as variações que ocorrem dentro de um recorte temporal. As variações sincrônicas podem ser diatópicas, sociais ou estilísticas. 


\subsection{2 - A variação diatópica}

Do grego, tópos ("lugar"), como o próprio nome diz, a variação diatópica compreende o conjunto de usos que se diversificam de acordo com a localização geográfica.

Em uma comunidade linguística relativamente extensa, as variações diatópicas envolvem, segundo Preti:

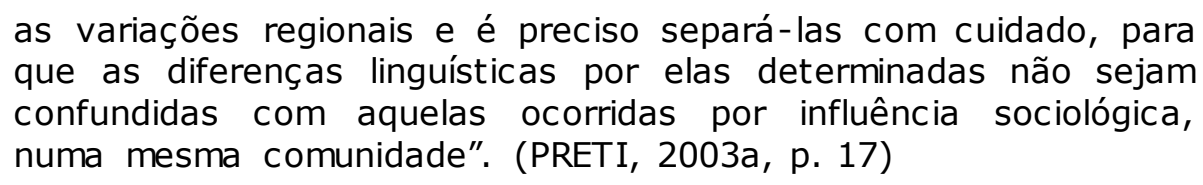
que as diferenças linguísticas por elas determinadas não sejam confundidas com aquelas ocorridas por influência sociológica, numa mesma comunidade". (PRETI, 2003a, p. 17)

A ressalva de Preti é muito relevante, visto que as "variações regionais" são distintas das variações sociais, embora em alguns casos também sejam socialmente desprestigiadas. A grande distinção entre ambas é que as variações diatópicas não estão alijadas da língua padrão.

No caso das variações lexicais, os dicionários de língua registram as diferentes lexias e antepõem rubricas indicando que são formas regionais. É o que acontece com "mandioca" e "abóbora", por exemplo. A mandioca é chamada de aipim ou de macaxeira, dependendo da região do Brasil, o mesmo ocorrendo com a abóbora, também chamada de jerimum.

No plano fonético, podemos mencionar a distinção de pronúncia do "I" no final de sílabas, que é vocalizado como "u" na maior parte do Brasil, exceto na região sul (RS, SC e parte do $P R$ ), onde é pronunciado como consoante alveolar. As duas formas ocorrem simultaneamente no Português Brasileiro e não parece haver concorrência entre ambas.

Segundo Preti, suas manifestações

são contidas na comunidade por uma hipotética linguagem comum do ponto de vista geográfico que, sendo geralmente compreendida e aceita, contribui para o nivelamento das diferenças regionais". (PRETI, 2003a, p. 24, grifo do autor)

Dessa forma, mesmo que determinados usos fonológicos ou lexicais sejam restritos a uma determinada região geográfica, a linguagem comum constitui um traço de intercompreensão entre os falantes, e tais distinções 
não se tornam um percalço para a interação. Assim, o "s" chiado do carioca não constitui um entrave para sua comunicação com um gaúcho ou um nordestino. Também, embora o lexema "jerimum" seja característico de parte da região Nordeste, seu emprego virtual por um nordestino em São Paulo ou no Rio de Janeiro não comprometeria a interação com outros falantes, visto ser um item lexical de significado amplamente conhecido.

\subsection{3 - A variação social ou diastrática}

As variedades diastráticas (de estrato, isto é, "camada", no sentido sociológico de grupo) compreendem um amplo leque de variações em uma determinada sociedade, de acordo com o estrato sociocultural do falante. A variação social, chamada por Preti de "variação sociológica", compreende

\footnotetext{
um conjunto de variações provenientes da idade, sexo, profissão, nível de estudos, classe social, localização dentro da mesma região, raça, as quais podem determinar traços originais na linguagem individual". (PRETI, 2003a, p. 17).
}

Essas variações estão ligadas a condições socioculturais dos falantes, tais como faixa etária (jovens e idosos não falam do mesmo modo), gênero (homens, mulheres e homossexuais podem se expressar de maneira diferente em determinados contextos), escolaridade (um analfabeto não se expressa da mesma maneira que um falante de nível superior), etc. As variações diastráticas podem ser influenciadas por fatores ligados ao grupo social, à situação de comunicação ou a ambos concomitantemente. Vejamos os fatores envolvidos, com base em Preti (2003a, p. 27 ss.):

a) Faixa etária. A variação referente à idade abrange a linguagem infantil (a deformação de significantes, o uso de hipocorísticos e o largo emprego de sufixos de diminutivo), a linguagem adolescente (a gíria jovem e o emprego de um vocabulário advindo da tecnologia) e a 
linguagem dos chamados "idosos velhos" (falantes acima de 80 anos, que tendem - em alguns estratos sociais - a empregar regionalismos e gírias de seu tempo de juventude).

b) Gênero. Aqui preferimos "gênero" a "sexo", pois há diferenças sensíveis não só na oposição homem/mulher mas também na oposição heterossexual/homossexual. A distinção de vocabulário, particularmente no emprego de tabuísmos, vem perdendo força nas últimas décadas, deixando de ser um fator distintivo da linguagem de homens e mulheres.

No campo da homossexualidade, há de se notar o emprego de uma gíria característica. Talvez a questão esteja mais relacionada a grupo social do que a gênero, mas os dois aspectos estão de certo modo interligados, visto que os homossexuais conquistaram um espaço relevante na sociedade, deixando de ser vistos apenas um "grupo social", mas impondo-se como um "terceiro gênero".

c) Posição social e escolaridade. Embora Preti separe os dois fatores (PRETI, 2003a, p. 28), optamos por referenciá-los em conjunto. Ainda que nem todos os falantes de alto nível de escolaridade pertençam às classes sociais mais favorecidas, o status de uma linguagem elaborada tende a não separar posição social de nível de escolaridade.

Embora o idioleto (saber linguístico individual) varie de pessoa para pessoa, há um conjunto de usos prescritos pela tradição que se impõe a falantes de prestígio social ou acadêmico. Por outro lado, usos em desacordo com a norma padrão são fortemente estigmatizados porque são característicos dos níveis de registro dos estratos baixos da sociedade, tanto no aspecto de posição social quanto no de cultura letrada.

\subsection{4 - A variação estilística ou diafásica}

A variação estilística ou diafásica (de fase) compreende um leque de variações referentes ao contexto situacional do falante. De acordo com 
Preti,

é possível estudar o problema sob o enfoque do uso que um mesmo falante faz da língua e de suas variedades, em função da situação, entendendo-se como tal as influências determinadas pelas condições extraverbais que cercam o ato de fala. Assim, a presença física do ambiente em que o diálogo ocorre pode ocasionar um nível de linguagem formal, fora dos hábitos normais do falante. (PRETI, 2003a, p. 37)

Essas variações, determinadas em função do contexto, compreendem o chamado nível de fala ou registro formal e o nível de fala ou registro informal (comumente chamado de "coloquial").

No registo formal, empregado em situações de formalidade, predomina a linguagem culta, mais elaborada, influenciada pelos cânones da língua escrita padrão.

Por outro lado, no registro informal, empregado em situações de informalidade, predomina a linguagem de uso popular (não culta), familiar, afetiva. Em alguns momentos, a linguagem informal faz uso de tabuísmos (vocábulos de uso vulgar), vocábulos gírios, entre outros.

\subsection{6 - Estabelecendo ligações: os níveis de linguagem}

Conforme pudemos notar, há uma estreita ligação entre a variação diastrática e a variação diafásica, o que resulta na ideia de níveis de linguagem ou níveis de registro.

Em primeiro lugar, é necessário distinguir

uma linguagem comum, manifestada por um conjunto de palavras, expressões e construções mais usuais, tidas geralmente como simples, mas corretas, de produção e compreensão entre o comum das pessoas (como conversações espontâneas normais, por exemplo). (URBANO, 2011, p. 28)

Essa linguagem comum constitui um nível de linguagem de intercompreensão entre os diversos grupos que compõem a sociedade.

A partir daí, ainda segundo o mesmo autor, tem-se, "em ordem crescente do ponto de vista da elaboração, a linguagem cuidada ou culta" 
e, "no sentido contrário, da espontaneidade, da despreocupação gramatical e correção linguística, tem-se a linguagem familiar e a popular (como conversações e bate-papos espontâneos)." (p. 28, grifos do autor)

Vimos, no item anterior, que a posição social e o grau de escolaridade são fatores de prestígio que caracterizam determinados usos linguísticos. Esses usos linguísticos prestigiados na sociedade constituem o que se convencionou chamar de "linguagem culta" ou "padrão". Influenciada pela escrita, em particular a literária, a língua culta constitui o conjunto de usos prestigiados e prescritos socialmente. O registro formal, em consonância com esse padrão, é o nível de linguagem que procura imitar ou reproduzir os modelos socialmente consagrados.

A escolarização formal exerce uma profunda influência a esse respeito, porque a escola tem o papel social de veicular a norma padrão, considerada o modelo de língua pela sociedade. Em tese, a norma padrão é o código da literatura, das leis, dos documentos, da mídia e de toda a escrita de uma sociedade letrada. Os usos linguísticos pautados pela norma padrão configuram o que Preti chama de "dialeto social culto" (PRETI, 2003a, p. 31). Esse dialeto social, segundo o mesmo autor

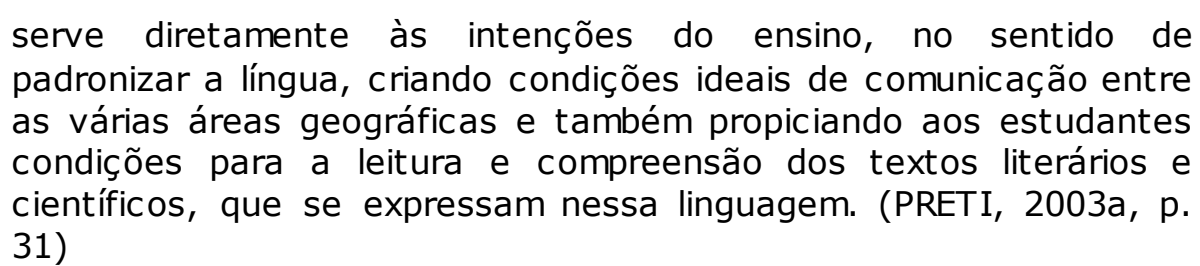
31)

No sentido contrário, fora desse padrão há um conjunto de variedades de uso não culto, socialmente estigmatizado, que tem o nome genérico de "linguagem popular". Urbano, entretanto, reconhece o caráter arbitrário dessas distinções e, muito acertadamente, esclarece:

Essas e outras distinções são bastante fluidas, uma vez que se estabelecem segundo critérios heterogêneos. A distinção linguagem popular/linguagem culta, por exemplo, apoia-se num critério sociocultural, ao passo que a distinção linguagem informal/linguagem formal se apoia, sobretudo, numa diferença de situação do evento conversacional, com realce para o papel dos falantes. (URBANO, 2011, p. 28-29)

Os critérios, ainda que heterogêneos, possuem um fundo em 
comum: são todos extralinguísticos, isto é, em termos de língua enquanto "sistema" a distinção culto/popular ou formal/informal não se sustenta. Trata-se de distinções socioculturais.

Embora a modalidade culta, chamada tradicionalmente de norma culta, seja a variedade de prestígio, ela não é, em essência, a única possível dentro do sistema da língua.

Seria possível, em tese, o emprego da modalidade popular nos mesmos moldes da modalidade culta. Mas, sem prestígio nem status de "língua", a modalidade popular é o quarto de despejo da língua, onde não se admite a presença da literatura e da língua escrita padronizada.

O que Carolina Maria de Jesus fez em sua obra foi levar a literatura para esse quarto de despejo figurativo, usando a modalidade popular como instrumento de expressão literária. Carolina trouxe a língua falada popular para as páginas de Quarto de despejo, e vários vocábulos de cunho popular denunciam essa oralidade latente. O emprego sistemático de vocábulos oriundos da fala popular ou de uso informal não é um mero "tropeço" ou "descuido" linguístico, visto que a ocorrência de tais vocábulos é sistemática e obedece a uma coerência interna do discurso.

Qualquer aparente "desvio", i. e., o que foge do padrão linguisticamente aceito, não é um fato não gramatical. Sua não aceitação se deve menos a fatores linguísticos que sociais. Novamente nos valemos das ponderações oportunas de Aléong, para quem:

todo comportamento é regulado por normas; não existe uma
norma única fora da qual qualquer outro comportamento seria
automaticamente errado. Muito pelo contrário, o real linguístico,
por mais diferente que possa ser de determinado código, não deixa
de responder a coerções linguísticas e sociais que podemos
observar e analisar. (ALÉONG, 2001, p. 174, grifos nossos)

Os usos linguísticos não padrão possuem tanta sistematicidade quanto a norma culta. É o que podemos depreender da conclusão de Aléong: "As distinções entre os universos ou os campos de aplicação das regras não se fazem, de modo nenhum, com critérios linguísticos, mas com base no jogo das normas sociais." (p. 174) 
Essas "coerções", ou "normas sociais" a que alude o autor, não impedem, entretanto, que manifestações típicas da língua falada não culta ou não padrão ${ }^{20}$ extravasem os limites (tênues, frisamos) da modalidade popular $^{21}$ e se façam presentes no texto escrito, principalmente no literário, tido como instrumento e exemplário das variedades de prestígio.

Contudo, essas distinções são importantes para nosso estudo, visto que os conceitos de língua escrita/língua falada estão essencialmente ligados a nível culto/nível popular e registro formal/registro informal. É o que veremos no tópico a seguir.

\section{2 - Modalidades linguísticas: o continuum fala/escrita}

Quando se trata de estudar as manifestações orais e escritas do discurso, a tarefa apresenta dificuldades, tendo em vista o "cipoal conceitual e terminológico", a que alude Urbano (2008, p. 21), condição que Koch e Oesterreicher (2013, p. 153-154) também reconhecem.

Em não poucas situações de produção, as duas modalidades se entrecruzam e configuram um texto híbrido. Entre múltiplas possibilidades, isso pode ocorrer em duas situações distintas, que se referem particularmente ao objeto deste estudo:

1. Na linguagem narrativa, quando o autor dá voz a um narrador em primeira pessoa, em que esse narrador é uma pessoa do povo ou uma pessoa em situação de informalidade, ou - como no caso de Carolina - quando os limites entre autor e narrador são difusos na mesma pessoa e o autor/narrador é uma pessoa de pouca escolaridade e os vestígios dessa condição sociocultural perpassam

20 Novamente lembramos que, embora oralidade e língua falada popular não sejam noções sinônimas, postulamos que há um grande ponto de intersecção entre ambas, visto que a língua escrita popular (em maior grau) e a língua escrita culta (em menor grau) estão sujeitas a interferências da língua falada popular.

21 Popular tanto pode se referir a "povo" como pode significar, na terminologia da Sociolinguística, "não culto". 
seu texto.

2. Na voz dos personagens, isto é, nos diálogos ou citações que reproduzem a fala de personagens em situação de interação ou em solilóquio, independentemente de essa representação se processar por meio de discurso direto ou indireto.

O fulcro da questão é que a fala e a escrita não são instâncias dicotômicas, mas polos de um continuum, em que ambos se imbricam. Segundo Marcuschi, "um dos aspectos centrais nessa questão é a impossibilidade de situar a oralidade e a escrita em sistemas linguísticos diversos, de modo que ambas fazem parte do mesmo sistema da língua." (MARCUSCHI, 2007, p. 38)

Na língua escrita, é possível transmitir ao leitor uma sensação de língua falada. De acordo com Preti,

é possível fazer chegar ao leitor a ilusão de uma realidade oral, desde que tal atitude decorra de um hábil processo de elaboração, privilégio do texto literário. O escritor emprega, na escrita, 'marcas de oralidade' que permitem ao leitor reconhecer no texto uma realidade linguística que se habituou a ouvir e que, pelo menos, já ouviu alguma vez e incorporou aos seus esquemas de conhecimento, frutos de sua experiência como falante. Esses esquemas são os responsáveis pelas suas estruturas de expectativa, isto é, o que o ouvinte (ou leitor) espera que o falante (ou escritor) fale (ou escreva) e em que tipo de linguagem o faça. (PRETI, 2004, p. 126)

Não obstante Preti fazer referência ao texto literário, essa "ilusão da realidade oral" também aparece em outros textos, particularmente naqueles escritos em uma variante não culta, o que não pressupõe uma "elaboração" propriamente dita, mas uma condição espontânea.

Logo, entendemos que, no Português popular escrito, essa "ilusão de uma realidade oral" não decorre de um processo de elaboração em si, mas também da própria competência linguística do autor, que explora os recursos da língua de maneira mais ou menos inconsciente.

No caso de nosso corpus, o texto revela um processo de 
amadurecimento intelectivo ${ }^{22}$ notável, embora deixe à mostra fortes marcas da língua falada popular.

Para Preti, a literatura sempre "encontrou problemas para elaborar a língua falada e, na maioria das vezes, é o vocabulário a única marca da oralidade na voz narrativa" (PRETI, 2004, p. 126). O que é um "problema" para falantes cultos (ou que fazem uso da modalidade culta) que desejam representar a língua falada, para um falante não culto, como é o caso de Carolina, praticamente essa representação, que seria a exceção, se torna a regra da organização textual. Efeitos como repetições, estruturas sintáticas não padrão e itens lexicais representativos da fala simples ocorrem de forma simples e espontânea.

Quando se fala em língua falada/língua escrita e nível popular/nível culto, está-se falando de manifestações diferentes da linguagem. Língua Falada (LF) e (LE) são as modalidades, enquanto nível popular e nível culto são os níveis de linguagem ${ }^{23}$.

O que ocorre, no entanto, é que quando se fala em presença da língua falada no texto escrito, geralmente se evocam os traços de registro popular na organização textual.

Elementos da língua falada, tais como pausas, hesitações, anacolutos, marcadores conversacionais, entre outros, quando representados na escrita, conferem efeitos de oralidade a esse tipo de texto.

Por outro lado, períodos longos e sintaticamente elaborados, além de um vocabulário mais amplo, conferem efeitos de escrituralidade ao texto falado.

22 A cultura paraescolar a que nos referimos anteriormente.

23 A rigor, "níveis de linguagem" e "níveis de registro" não se referem à mesma realidade. "Níveis de linguagem" são os níveis da variação diastrática, enquanto "níveis de registro" são os níveis da variação diafásica. Entretanto, como tais conceitos são bastante fluidos e estão inter-relacionados, acabam sendo empregados de maneira intercambiável. Assim, com certa liberdade terminológica, adotamos neste trabalho os dois termos sem fazer uma distinção rígida. 
Tais superposições de características evidenciam o aspecto híbrido de determinados tipos de discurso. A este respeito Koch e Oesterreicher apontam

o fato de determinados enunciados orais apresentarem, em seu aspecto formal, poucas diferenças em relação a enunciados escritos e, por outro lado, de determinados textos escritos possuírem marcas nítidas da oralidade. ( $\mathrm{KOCH} \&$ OESTERREICHER, 2013, p. 154)

Em que pesem as evidentes distinções entre texto falado e texto escrito, há profundas relações entre ambos que devem ser levadas em conta, pois muitos textos escritos apresentam características orais e viceversa. Ingedore Koch, na mesma linha de raciocínio de Koch e Oesterreicher, assevera:

os diversos tipos de práticas sociais de produção textual se situam ao longo de um contínuo tipológico, em cujas extremidades estariam, de um lado, a escrita formal e, de outro, a conversação espontânea, coloquial. (KOCH, 2006, p. 43)

Embora língua falada e nível popular não sejam noções intercambiáveis, acontece que, ao lado de uma língua falada culta (de falantes escolarizados, que têm a língua escrita como modelo) há uma língua falada não culta, com nítida tendência para usos menos formais.

De certa maneira, porém, o equívoco terminológico tem uma razão de ser. Os respectivos polos das modalidades da enunciação e dos níveis de registro parecem ter certa correspondência, o que resulta em uma superposição terminológica. Koch e Oesterreicher, de modo muito feliz, discerniram o assunto:

naturalmente existem afinidades entre a linguagem oral e escrita e
determinadas variações... Desse modo, variedades diatópicas
fortemente marcadas (dialetos, regioletos) possuem proximidade
com a oralidade, assim como variedades diastráticas classificadas
como "baixas" ("linguagem popular", gírias). Do ponto de vista da
variação diafásica, a proximidade de registros "inferiores" (familiar,
vulgar etc.) com a oralidade é tão evidente que, ao longo da
história das pesquisas linguísticas, não raramente foi estabelecida
uma identificação entre ambos, como, por exemplo, no conceito de
"língua coloquial", (KOCH \& OESTERREICHER, 2013, p. 155). Desse modo, por extensão, a influência da língua falada na escrita também se manifesta por meio de elementos do registro popular, 
denominado por Preti de "dialeto social popular" (PRETI, 2003a, p. 32).

Essa convergência entre as modalidades e os níveis de registros pode ser visualizada no quadro abaixo, em que tentamos sintetizar a questão.

Tabela 04 - Confluência entre Modalidades e Níveis de Registro

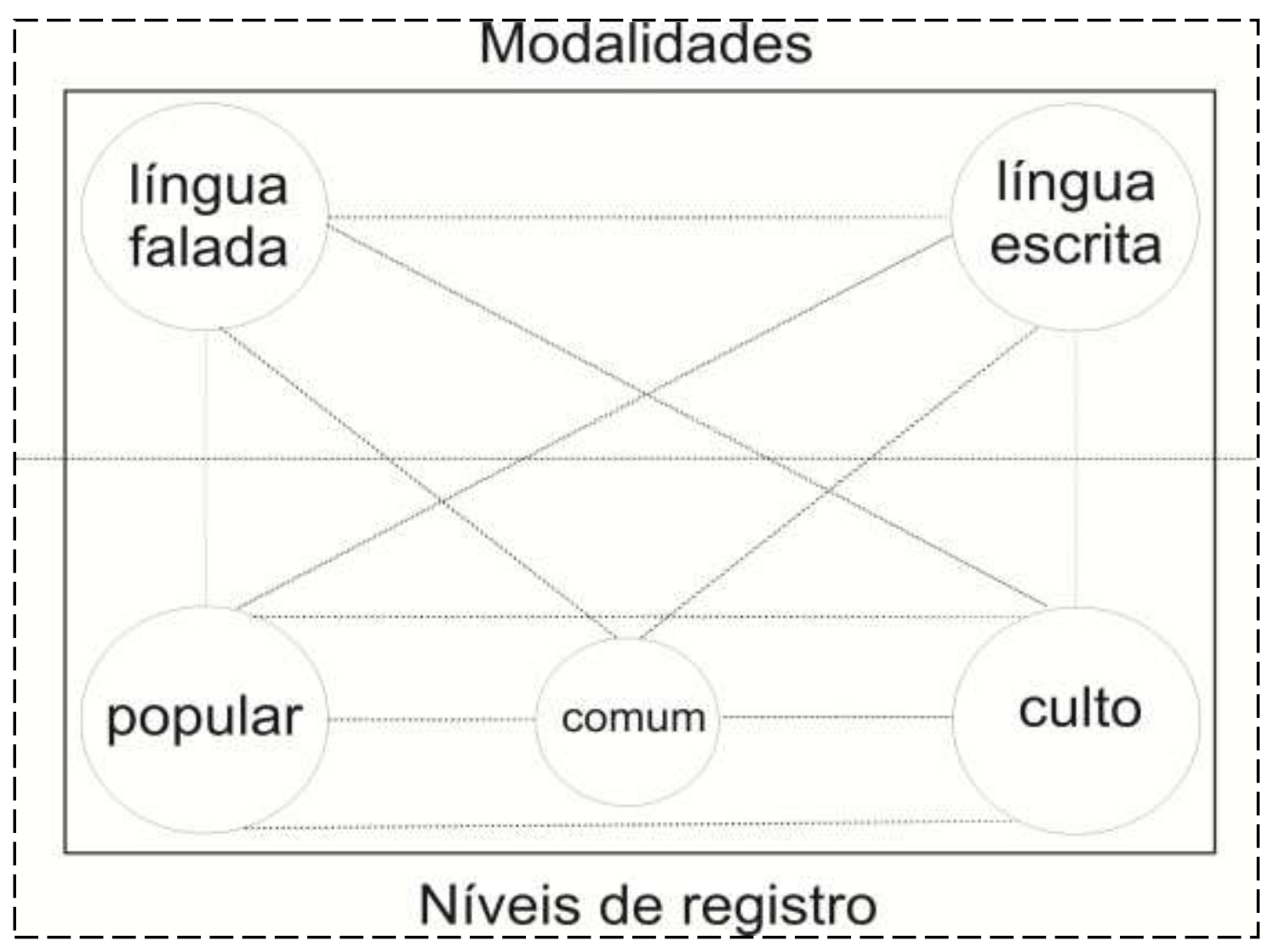

$\mathrm{Na}$ tabela acima estão sintetizadas as confluências entre modalidades e níveis de registro. Há uma correspondência entre língua falada e o nível popular e entre a língua escrita e o nível culto. Nos dois casos há um continuum, uma zona intermediária de limites fluidos.

Entre a língua escrita e a língua falada, há um número expressivo de textos híbridos, que são enunciados em um meio (gráfico ou sonoro), mas concebidos em sentido diametralmente oposto. 
Um texto estritamente formal e despersonalizado como artigo ou alínea de uma lei é um exemplo de texto escrito prototípico, enquanto um ato conversacional espontâneo é o exemplo de um texto oral prototípico. Mas entre esses polos há uma grande variedade de textos de natureza heteróclita, com características das duas modalidades.

Uma conferência acadêmica, uma comunicação em evento científico ou uma aula magna, por exemplo, são textos medialmente orais porquanto veiculados por meio sonoro; entretanto, não foram gerados oralmente, no momento de sua enunciação, mas gerados previamente e por escrito. São textos híbridos porque transitam entre a oralidade e a escrita, isto é, possuem características das duas modalidades de enunciação. É correto, portanto, postular a presença de escrituralidade, isto é, de marcas de elaboração escrita em textos orais.

Da mesma maneira, um bilhete escrito no ambiente doméstico ou um diálogo tabulado por escrito em meio eletrônico, como nas redes sociais, por exemplo, são textos medialmente escritos porquanto veiculados por meio gráfico; contudo, não foram gerados previamente, elaborados por escrito, mas gerados espontânea e concomitantemente ao ato enunciativo. Assim como os exemplos citados no parágrafo anterior, também são textos híbridos porque transitam entre a oralidade e a escrita, igualmente apresentando características de ambas as modalidades. De maneira análoga, é correto também postular a presença da oralidade, isto é, de marcas da enunciação falada em textos escritos.

Oesterreicher afirma que esses textos de caráter híbrido pertencem a uma tradição discursiva "inversa", corroborando o que afirmamos anteriormente:

con todo, hay de admitir que existen tradiciones discursivas 'inversas'; así, una 'carta privada' combina la concepción hablada com el medio gráfico y una 'conferencia' combina la concepción escrita com el medio fónico. Además, existe siempre la posibilidad de un cambio medial em qualquier enunciado. (OESTERREICHER, 
1996, p. 319$)^{24}$

Assim como língua falada e língua escrita prototípicas constituem extremidades de um continuum tipológico, a linguagem de uso popular e a linguagem de uso culto ${ }^{25}$ parecem ter uma correspondência, constituindo, convencionalmente, extremidades dos níveis da linguagem.

No campo do léxico, o vocabulário específico de uma lei ou das ciências representa o uso culto em seu ápice. Assim, termos jurídicos (tais como "mandado de segurança", "impetrar", "estágio probatório", por exemplo) ou da medicina (tais como "ir a óbito", "colonoscópio", "otalgia", por exemplo) constituem usos lexicais de natureza culta. Podemos considerar tais vocábulos como prototípicos da escrituralidade, isto é, situados concepcionalmente no polo da modalidade escrita da língua, sendo, portanto, tendencialmente menos falados (- falados) e mais escritos (+ escritos).

Por outro lado, vocábulos gírios ou de uso considerado vulgar, como "transar" (ter relações sexuais) ou "baseado" (cigarro de maconha) constituem usos lexicais não cultos, ou populares em sentido estrito ${ }^{26}$. Neste espectro também se encontram um número extenso de vocábulos não necessariamente gírios ou vulgares, mas restritos a um uso mais informal da língua, quer por falantes cultos, quer por falantes do povo. São itens lexicais de menor prestígio social, não considerados de bom alvitre para o uso de uma linguagem elaborada. Em sentido oposto à escrituralidade, são vocábulos prototípicos da oralidade, ou seja, situados concepcionalmente no polo da modalidade falada da língua, sendo,

24 Contudo, há de se admitir que existem tradições discursivas "inversas"; assim, uma "carta íntima" combina a concepção falada com o meio gráfico e uma "conferência" combina a concepção escrita com o meio fônico. Ademais, existe sempre a possibilidade de uma troca medial em qualquer enunciado.

25 São implicações basicamente culturais e sociais e não estritamente linguísticas. Por falta de uma nomenclatura mais adequada, adotamos essa consagrada pela sociolinguística. Mesmo que substituamos "culto" por "padrão" o problema persiste. Talvez seja um termo mais adequado. Empregaremos ambos de forma intercambiável.

26 Neste trabalho adotamos a proposta de Urbano (2011, p. 29 ss.), que compreende "popular" em dois sentidos: aquilo que "é próprio do povo" e o nível de linguagem "não culto" ou "não padrão". Assim, linguagem "popular" tem o sentido de linguagem "não culta". 
portanto, tendencialmente menos escritos (- escritos) e mais falados (+ falados).

Como podemos perceber, trata-se de uma distinção mais ligada ao papel social dos falantes e aos contextos de produção do que ao sistema linguístico, visto que todos fazem parte do léxico como conjunto das unidades da língua. Qualquer vocábulo em "estado de dicionário" é, em tese, neutro. Como as palavras não são presas ao dicionário como peças de um museu, ao serem postas em circulação ficam subordinadas ao uso que the emprestam seus falantes.

Da mesma maneira como há certos itens lexicais que podemos considerar "prototípicos" da língua falada ou da língua escrita, há uma quantidade incontável de vocábulos de uso comum, de alta frequência, que podem ser empregados tanto na linguagem considerada padrão quanto na linguagem popular (não padrão).

Os nomes das partes do corpo (cabeça, mão, pé), meios de transporte (metrô, ônibus, carro), antropônimos (José, Maria, Paulo), topônimos (Rua da Consolação, Metrô Vila Mariana, Perdizes, Maringá), por exemplo, entre um amplo espectro de categorias, subcategorias e designações, constituem um léxico de uso intermediário, chamado por Preti de "linguagem comum" (PRETI, 2003a, p. 33).

Naturalmente, conforme mencionamos anteriormente, há uma correspondência entre as modalidades e os níveis de registro, conforme a tabela da página 91. Há uma estreita ligação entre Língua Escrita e o Dialeto Social Culto, bem como entre a Língua Falada e o Dialeto Social Popular.

Dizemos que há ligação, mas não que sejam sinônimos, pois há uma língua falada culta e uma língua escrita popular. Todavia, as zonas intermediárias entre as modalidades e os níveis de registro tornam a descrição linguística mais trabalhosa do que se poderia erroneamente esperar. 
De modo geral, podemos sintetizar essas relações assim:

Tabela 05 - Língua Falada (LF)

\begin{tabular}{|l|l|}
\hline CULTA & $\begin{array}{l}\text { variedade de prestígio, empregada pelos falantes cultos } \\
\text { em situação de formalidade; apesar de ter por parâmetro } \\
\text { a Língua Escrita considerada formal, é bastante flexível e } \\
\text { apresenta, em determinadas circunstâncias, traços de } \\
\text { informalidade. }\end{array}$ \\
\hline COMUM & $\begin{array}{l}\text { intermediária, constitui a chamada "linguagem comum", } \\
\text { isto é, um hipotético ponto de encontro entre a vertente } \\
\text { culta e a vertente popular, principalmente em situações } \\
\text { de interação entre falantes de estratos sociais diferentes. }\end{array}$ \\
\hline POPULAR & $\begin{array}{l}\text { não culta ou "do povo", chamada por PRETI de "dialeto } \\
\text { social popular", constitui a fala dos usuários não cultos, } \\
\text { isto é, dos usuários de escolaridade limitada ou nula. } \\
\text { Assim como sua correspondente escrita, a língua falada } \\
\text { popular é socialmente desprestigiada. Ressalve-se que, } \\
\text { embora essa distinção tenha um caráter mais social do } \\
\text { que linguístico, muitos falantes, mesmo de formação } \\
\text { universitária ou condição social abastada, falam essa } \\
\text { modalidade, seja devido a suas origens sociais, seja por } \\
\text { suas limitadas práticas de leitura e escrita. }\end{array}$ \\
\hline
\end{tabular}

Tabela 06 - Língua Escrita (LE)

\begin{tabular}{|l|l|}
\hline CULTA & $\begin{array}{l}\text { prestigiada e fixada culturalmente como padrão, é } \\
\text { empregada nos meios de comunicação e nos textos } \\
\text { escritos de uso formal mais acentuado, em que se exige } \\
\text { do usuário um maior grau de automonitoração e de } \\
\text { elaboração linguística }\end{array}$ \\
\hline COMUM & $\begin{array}{l}\text { intermediária, é empregada em situações de formalidade } \\
\text { relativa, de menor automonitoramento linguístico; assim } \\
\text { como a LF comum, a língua escrita comum também } \\
\text { constitui um ponto de intersecção entre diferentes grupos } \\
\text { sociais; }\end{array}$ \\
\hline POPULAR & $\begin{array}{l}\text { estigmatizada e desprestigiada, é empregada por falantes } \\
\text { menos escolarizados em situações de uso informal mais } \\
\text { acentuado. }\end{array}$ \\
\hline
\end{tabular}

4.3 - A representação da oralidade no texto literário 
A linguagem literária é uma manifestação da linguagem de características difusas, tanto na questão da modalidade (literatura escrita, literatura oral) quanto na questão do registro (linguagem que pode perpassar os três níveis). Desse modo, poderíamos vislumbrar a linguagem literária num ponto imaginário entre diferentes modalidades e níveis de registro.

No texto literário, em particular um texto com as peculiaridades de Quarto de despejo, as distinções entre modalidades e níveis de registro não são tão nítidas e acabam por se embaralhar. Claro que o texto literário, no suporte do livro, é um texto escrito e não um texto oral. Entretanto o aqui/agora do indivíduo, a sua realidade quotidiana, se manifesta no texto não apenas tematicamente como também linguisticamente, visto ser vivido pelo indivíduo.

Sapir já reconhecia a presença de recursos da fala no texto escrito, particularmente no texto literário:

É lícito ao artista utilizar-se dos recursos estéticos naturais da fala. Deve sentir-se feliz em ter uma palheta rica em cores, um trampolim favorável. Mas se levem a seu crédito os bons achados que decorrem da própria língua. Cumpre-nos dar por admitida a presença da língua com toda a sua flexibilidade ou rigidez, e ver a obra do artista em relação a ela. (SAPIR, 1980, p. 177)

Talvez seja muito genérico falar em "recursos estéticos naturais da fala", mas certos fenômenos da fala conferem espontaneidade, dinamicidade e proximidade ao texto escrito, mesmo o não literário. É o que notamos, por exemplo, em textos publicitários ou manchetes jornalísticas. Certos recursos estéticos causam impacto no público a o qual é dirigida a mensagem.

No caso do texto literário em particular, embora seja tomado tradicionalmente como o modelo de língua padrão, suas intenções estéticas não raro o afastam dos influxos da norma. Esse paradoxo foi descrito por Preti:

Sendo uma manifestação escrita, o texto literário pressupõe um processo de elaboração, de reflexão, de planejamento, que se afastaria, em tese, da dinâmica da língua oral espontânea, que se 
desenvolve, não raro, de forma imprevista, em face da situação interacional. Mas, por outro lado, os objetivos do escritor são de natureza estética e não há limites na escolha das variantes linguísticas para atingi-los. (...) Dificilmente se poderia aceitar a ideia de uma "língua literária", no sentido de uma "língua exemplar", isto é, um modelo padrão de língua culta. (PRETI, 2004, p. 120)

No texto narrativo, a linguagem refletirá o contexto situacional e os níveis socioculturais das personagens, o que estabelece uma relação de pertinência entre o contexto e a linguagem, conforme Urbano elucida:

Quando consideramos o falante, o ouvinte e a situação (tema,
lugar, tempo etc), pensamos nas respectivas características e nas
recíprocas relações entre esses elementos. Teoricamente, ao
menos, haverá tantas variedades linguísticas, quantas sejam essas
características e relações. (URBANO, 2000, p. 72-73)

Essa representação das variantes linguísticas no texto escrito se dá de maneira particularmente notável pelo emprego de um léxico característico da linguagem popular.

Dessa forma, reiteramos o que já foi exposto anteriormente: embora não sejam conceitos análogos, trabalharemos com a noção do léxico popular como marca de oralidade no texto escrito, assim como a recíproca também é verdadeira: o léxico de uso culto também constitui uma marca de escrituralidade em textos orais.

Mas uma pergunta decorre dessa perspectiva: como traçar o caráter popular de uma determinada lexia? Os dicionários de língua e os de gíria podem servir de critério preliminar. Isto é o que veremos a seguir.

4.4 - O dicionário como ferramenta para o estudo do vocabulário de uso oral

Como estabelecer critérios para distinguir vocábulos "cultos" de "não cultos"? Não seremos impressionistas ao nos reportarmos a um lexema e apreendê-lo como culto ou popular? Acreditamos que este é um problema, em essência, insolúvel. Quem melhor compreendeu essa questão foi Preti, 
ao afirmar que

o léxico representa para o linguista um campo de difícil análise, pelas implicações culturais que possui e porque nele, mais do que em nenhum outro, se observa melhor a condição dinâmica da língua, sua contínua renovação para atender às necessidades de comunicação, fato que reflete a mobilidade das estruturas sociais, que também se renovam incessantemente. (PRETI, 2010 [1984], p. 79, grifos nossos)

A depreensão de itens lexicais como "populares" ou "cultos" é extralinguística e, portanto, possui inequívoca implicação sociocultural. Por ser extralinguística e não intralinguística é que sua depreensão dependerá muito da competência do falante, seja o usuário comum da língua em momento de interação (quando precisa selecionar seu repertório vocabular de acordo com a situação), seja o linguista (para analisar o vocabulário de um determinado corpus).

Um critério de balizamento preliminar é o dicionário de língua e o dicionário de gíria, mas ainda assim caímos no "pecado original" do estudo lexical de caráter sociolinguístico: que critérios usou o dicionarista para classificar um vocábulo como "brasileirismo", "popular", "coloquialismo", "chulo", "gírio" ou "vulgar"?

Embora Preti se refira especificamente aos dicionários de gíria, seu juízo aplica-se a toda obra lexicográfica: "pesa, sobretudo, a experiência pessoal do próprio lexicógrafo." (PRETI, 2004, p. 78) O autor também assevera, ao discorrer sobre a gíria:

Essa variante lexical, em geral, é ligada a situações de comunicação menos formais ou a interlocutores menos cultos, razão pela qual os vocábulos gírios, frequentemente, vêm rotulados com outras rubricas, como vulgar, popular, etc. Do ponto de vista linguístico, essa classificação não corresponde a uma verdade e é simplesmente inadmissível, pois externa um julgamento pessoal do lexicógrafo, não raro motivado por estereótipos que associam a gíria à irreverência dos jovens ou à marginalidade. (PRETI, 2004, p. 77)

O autor se reporta à gíria, mas suas conclusões interessam a toda a esfera de vocábulos não cultos: em termos estritamente linguísticos, a oposição culto/popular "não corresponde a uma verdade"...

Trata-se, portanto, de um problema circular: um vocábulo é popular, 
nós o reconhecemos assim e, o dicionário, em diversos casos, também reconhece, mas seu autor, mesmo que o tenha coletado da imprensa ou da literatura, também partiu de uma impressão pessoal. Estamos diante do "pecado original da sociolinguística": ser uma expressão popular ou culta depende do contexto, da situação, do uso e da tradição, fatores - a priori - extralinguísticos. A rigor, não há como provar, empírica e cientificamente, que um vocábulo é popular ou culto. Sempre teremos que contar com a nossa percepção. Isso não é necessariamente um grande mal: como pessoas que vivem em sociedade, os usuários de uma língua contam com um repertório vocabular que lhes permite acionar ou substituir vocábulos de acordo com a sua necessidade interacional ${ }^{27}$.

Por isso falamos em "pecado original da sociolinguística": a ciência jamais deveria ser "impressionista", mas o estudo do léxico, pelo menos deste porte, dependerá muito de nossa experiência pessoal.

Nosso desafio é depender o mínimo possível da experiência e contar com critérios, mesmo que sejam mínimos e, em essência, frágeis para a caracterização do léxico de uso popular.

Desprezando a condição de que o dicionarista também contou com sua experiência, o dicionário de língua e o de gíria são ferramentas para um balizamento preliminar da condição de uso de muitos vocábulos.

Em nosso caso, ao analisarmos Quarto de despejo nos deparamos com diversos itens lexicais com rubricas do tipo no dicionário de língua, conforme as quatro a seguir, extraídas de Houaiss (2001):

(1). Coloq. (coloquialismo) - embora a rigor a palavra "coloquial" se refira à língua falada conversacional, o termo adquiriu o sentido de "informal".

27 Muitos dos vocábulos de uso intrinsecamente popular são estáveis, isto é, possuem datação antiga na língua e fazem parte da coletividade. Os vocábulos de uso vulgar, por exemplo, e dentro dessa categoria são incluídos os obscenos, possuem o traço de interdição social há muito tempo e têm passado de geração para geração com esse traço. Reportar-nos-emos a esta questão mais adiante. 
(2). Infrm (informal) - Houaiss, por exemplo, assim explica em sua edição eletrônica: "neste dicionário, o termo informal (infrm.) abarca variantes linguísticas que em outros dicionários são classificadas como popularismo, plebeísmo, gíria, linguagem familiar, linguagem infantil etc." Ex: besta (muito admirado ou pasmo).

(3). Bras. (brasileirismo) - os vocábulos classificados como "brasileirismos", como o próprio nome indica, são característicos da língua falada no Brasil e limitados na língua escrita formal. Houaiss: "sob o ponto de vista lexical, palavra ou locução (dialetismo vocabular) ou acepção (dialetismo semântico) privativa do português do Brasil". Podemos citar como exemplos os regionalismos.

(4). Ch. (chulo) - itens lexicais de baixo calão, grosseiros, obscenos. Ex: tesão (desejo sexual por alguém)

Além dessas marcações dos dicionários de língua, tais lexemas também são reunidos nos chamados dicionários de gíria, que recolhem, sob sua égide, não apenas vocábulos gírios, mas também outros de uso popular ou que vieram a se popularizar após sua catalogação, o que torna problemática a própria natureza e a proposta desse tipo de obra.

4.5 - Traços da oralidade no plano lexical: características do vocabulário popular

4.5.1 A linguagem informal: vocabulário referente à pobreza e ao quotidiano do povo

Há vocábulos cultos que podem ser substituídos na linguagem corrente por outros de uso informal, linguisticamente distensos. Esses usos vocabulares ocorrem não apenas na fala popular propriamente dita, 
mas ocorrem também na fala de pessoas cultas em situação de menor automonitoramento linguístico. Podemos incluir como exemplos de linguagem informal o emprego de expressões cristalizadas ou clichês.

Também há certos itens lexicais referentes à pobreza e à vida quotidiana do povo. Nem todos são intrinsecamente populares, sendo até de difícil delimitação como tal, mas seu uso dentro do contexto da obra Ihes confere um caráter popular ou informal.

Para um falante mediano ou culto não será difícil reconhecer, entre o amplo espectro de escolhas disponíveis no sistema linguístico, que vocábulos são mais adequados à língua escrita e, por extensão, ao registro formal.

Há, no decorrer da narrativa de Quarto de despejo, tanto na voz dos personagens quanto na voz da narradora, um significativo número de itens lexicais que, embora não sejam gírios, podem ser enquadrados no que, grosso modo, reportamos como itens lexicais utilizados por um número significativo de falantes mas não aceitos para o emprego na linguagem de uso considerado formal.

Por "uso formal" entende-se o uso da modalidade escrita dita padrão, empregada em situações de comunicação tais como a escrita jornalística, a escrita acadêmica e outras esferas sociais em que o emprego de um registro linguisticamente distenso e popular é indesejável e repelido.

Assim, por se tratar de uma questão social, reconhecemos o caráter arbitrário dessa classificação e postulação. Entretanto, todo falante culto ou mediano possui uma percepção construída ao longo de anos de escolarização formal e interação em sociedade, que the permite reconhecer usos vocabulares socialmente interditados à linguagem chamada padrão, típica da modalidade escrita formal, que se espera ser do seu conhecimento.

Em sentido lato, entendemos por vocábulos de uso informal todos 
aqueles empregados na comunicação (tanto oral quanto escrita) presentes no repertório linguístico dos falantes, mas não aceitos como uso formal de boa qualidade pela maioria.

Tais vocábulos, por essa restrição de uso, ficam circunscritos à língua falada e são empregados na escrita em circunstâncias especiais. No gênero jornalístico, por exemplo, afeito ao imediato e à intencionalidade de conquistar leitores, o emprego de vocábulos de uso informal confere expressividade a manchetes e artigos, ao mesmo tempo em que constitui um repositório da língua de sua época. Não raro encontraremos na língua escrita da imprensa vocábulos como "laranja" ou "maracutaia", de uso informal, empregados com bastante naturalidade e sem autocensura, impensáveis na escrita jurídica, acadêmica ou científica, por exemplo, que exigem maior "apuro" vocabular.

4.5.2 - A gíria como elemento expressivo da linguagem popular

A gíria é uma linguagem especial, empregada por determinados grupos sociais. Diferencia-se do jargão porque não é de uso técnico ou referente a uma determinada profissão. A gíria é um "signo de classe" (CABELLO, 1987, p. 06) e seu uso proporciona senso de solidariedade aos membros de um determinado grupo social, servindo como traço distintivo em relação à sociedade como um todo.

Essa distinção vocabular resulta em itens lexicais de emprego específico, referentes a um determinado universo e desconhecidos para pessoas alheias ao grupo. Na realidade, essa é a intenção explícita da gíria: constituir um código secreto, de uso exclusivo dos seus usuários, que dificulte (ou impossibilite) a sua decodificação por parte de pessoas alheias ao grupo.

A gíria se forma basicamente por metáfora e por metonímia, em que se atribui a uma palavra já existente na língua um sentido diferente do 
primitivo, tanto que Cabello a considera, com base em Preti (1984, p. 6),

um vocábulo de caráter parasita, na medida em que ela outra coisa não faz senão desdobrar com valores afetivos diferentes um vocábulo já existente, empregado numa determinada camada da sociedade que se põe em oposição às outras" (CABELLO, 1987, p. 31)

Por exemplo, o substantivo "Ioja" como sinônimo de ponto de venda de drogas ilustra com bastante nitidez a afirmativa da autora: a partir de um vocábulo já existente, "Ioja" (estabelecimento comercial), criou-se, por afinidade semântica, um sentido peculiar para a palavra, isto é, "ponto de venda de drogas". Não houve criação de um sintagma, mas a absorção de uma palavra já existente, por isso o "caráter parasita" que ela possui no léxico de uma língua.

O mesmo pode-se afirmar a respeito de grande parte dos vocábulos gírios, independentemente do grupo que a empregue. Embora já exista na língua o sintagma "pão com ovo", a gíria homossexual adaptou-o, dandoIhe o sentido de "homossexual pobre, sem posses".

Deduzimos, a partir dos dois exemplos, que a gíria se forma a partir de um traço semântico comum entre o sentido primitivo e o sentido derivado. Em "Ioja", a ideia de um estabelecimento para compra e venda de um produto criou a acepção de local, mesmo ao ar livre, para a venda de entorpecentes; trata-se de uma metáfora concreta, típica da língua falada. Em "pão com ovo", a ideia de um alimento simples e barato criou a acepção, por metonímia, de uma pessoa sem posses. A pessoa passa a ser designada por aquilo que supostamente consome.

Apesar do "caráter parasita" da gíria, longe está de ser um vocabulário "pobre" e "sem cultura", conforme se diz comumente. Sua formação envolve aspectos semânticos presentes na formação de qualquer outro vocabulário.

Preti dá os seguintes exemplos: "mamar (obter lucro de alguma coisa), grude (comida), branquinha (cachaça), bolha (pessoa desagradável), fossa (desânimo), piranha (prostituta) etc." (PRETI, 1984, 
p. 5-6). O mesmo autor acrescenta que a gíria também se forma pela deformação de significantes, e cita os exemplos "velhusca, loteca, carango, sastifa, prafrentex, debiloide, vivaldino etc". (id., p. 6)

Ainda que surja como um signo de grupo, isto é, um vocabulário de uso restrito a um grupo social específico, dada à própria dinamicidade intrínseca à língua e às relações sociais, não raro a gíria acaba por se vulgarizar e sai dos limites do grupo, penetrando na linguagem comum. Conforme entende Preti, "vocábulos que se ligam a certos grupos ou atividades específicas passam a se vulgarizar, entrando para a linguagem comum." (PRETI, 2003b, p. 55)

Pensemos, por exemplo, na gíria adolescente, dos criminosos ou dos homossexuais. Os membros de tais grupos não interagem apenas entre si. Naturalmente, nesse processo interacional o seu vocabulário acaba se difundindo, e alguns de seus itens lexicais podem se tornar a chamada "gíria comum".

Conforme postula Preti,

ao vulgarizar-se para a grande comunidade, assumindo a forma de gíria comum, de uso geral e não-diferenciado, esse vocabulário perde-se dentro dos amplos limites de um dialeto social popular, deixando, desde então, de ser signo grupal. Nesse momento, torna-se difícil precisar o que é de fato vocábulo gírio ou vocábulo popular. (PRETI, 1984, p. 3)

Gírias adolescentes da década de 1960, como "quadrado" ou "careta" acabaram por se incorporar à linguagem comum de sua época, sendo empregadas por pessoas externas ao grupo.

No caso de Quarto de despejo, a favela não só constituía um grupo social marginalizado como também abrigava pessoas ligadas à marginalidade, conforme relata Carolina em diversas passagens. Nesse respeito, os usos em Quarto de despejo são bastante significativos, por não ocorrerem somente na voz de personagens, mas também na voz da narradora.

Isso implica, a nosso ver, que mesmo sendo vocábulos gírios e já 
dicionarizados à época como tal, já se haviam incorporado à linguagem popular, ou, como diz Preti, ao "dialeto social popular", constituindo o que o mesmo autor chama de "gíria comum".

Os vocábulos gírios, já dicionarizados na época, aparecem com relativa frequência ao longo da obra, tanto na voz da narradora quanto na voz de personagens. Sobre a presença da gíria na linguagem popular, Urbano assim se manifesta:

Com ou sem o caráter criptológico de linguagem de grupo, a gíria se manifesta mais profusamente em grupos de malandros, comunidades de favelas, grupos de jovens, mas também como vocabulário agregado à linguagem cotidiana, e, assim, aparece em conversas do dia a dia e em músicas, cinema, teatro, literatura. (URBANO, 2011, p. 93)

Um mesmo indivíduo pode pertencer a grupos diferentes e interagir com outros de grupos distintos. É uma forma natural de propagação vocabular.

Com as mudanças sociais advindas de uma liberalidade nos costumes a partir da década de 60, a gíria, antes restrita a grupos, passou a ser empregada com maior naturalidade até nos meios de comunicação.

4.5.3 - Desenfoque semântico: imprecisão, generalização e deturpação de sentido

Na língua falada, é muito comum o uso de palavras com sentido impreciso ou genérico. A maior abundância de nuances de significação é uma característica típica da linguagem culta.

De acordo com Preti,

encontramos maior variedade na linguagem culta, maior precisão no emprego dos significados, maior incidência de vocábulos técnicos, enquanto na popular predomina um vocabulário restrito, de uso muito amplo nos mais diversos sentidos, muitas vezes abusivo na gíria e nos recursos enfáticos, como os termos obscenos. (PRETI, 2003a)

Na mesma linha de pensamento, Urbano esclarece: 
Muitas palavras usadas na fala popular o são também na língua padrão, outras são deslocadas da área semântica da variedade culta, outras apresentam "atrevidas metáforas", outras nascem do seio mesmo do povo, outras ainda cristalizam-se, reduzidas ou deformadas foneticamente. Cabe advertir, porém, que é muito difícil estabelecer distinções entre vocabulário culto e popular e entre fala e escrita. (...) A diferença é que tais palavras são empregadas, no dialeto culto, de maneira mais consciente e precisa do que no popular. Neste, o mesmo vocábulo apresenta muitas vezes generalizações e imprecisões de sentido. (URBANO, 2000 , p. 123, grifos nossos)

Em Quarto de despejo há várias ocorrências, inclusive de palavras cultas, com sentido impreciso, vago, genérico ou deslocado.

Essa imprecisão de sentido a que aludem ambos os autores encontra eco na afirmação de Barbosa, que usa o termo "desenfoque semântico":

Muitas vezes, ao procurar dar conta de uma análise da
experiência, o sujeito falante, no processo de enunciação, atualiza
uma unidade lexical, ou a substitui por outra, alterando a
combinatória semêmica e a desfigurando, em maior ou menor
grau, a significação - entendida como valor de comunicação - a
que se propunha. (BARBOSA, 1981, p. 231, grifos nossos)

Há de se notar que a autora caracteriza esse processo como uma "queda no nível do desempenho, geradora de ruído na comunicação". (BARBOSA, 1981, p. 232)

Essa "queda no nível do desempenho" se dá porque se trata de um vocabulário limitado que poderia ser expandido por um leque maior de escolhas com sentido preciso e definido.

Entre os diversos fatores mencionados por Barbosa que podem determinar a ocorrência do desenfoque semântico, há dois que nos parecem pertinentes à narrativa de Quarto de despejo: "a ausência, no inventário léxico do falante, de vocábulos que permitam a análise de uma experiência, com a suficiente especificidade sêmica, de que resulta uma perda de especificidade do discurso" (BARBOSA, 1981, p. 233) e "em função de demonstrar riqueza ou ocultar pobreza de vocabulário, a utilização pelo sujeito falante... de vocabulário passivo... em lugar do vocabulário ativo". (id., p. 233-234) 
Nesse leque de palavras e expressões de sentido impreciso, destacamos a ocorrência de palavras-ônibus, isto é, itens lexicais de sentido genérico de largo emprego na língua falada com a finalidade de substituir outros.

Essa substituição acontece porque o usuário desconhece o vocábulo exato ou porque, em situação de interação, haja vista a rapidez e o dinamismo dos turnos na conversação, não consegue acioná-lo de seu repertório vocabular. $\mathrm{Na}$ linguagem popular são correntes as palavras coisa, negócio e troço, geralmente de significação ilimitada.

O item lexical "coisa", por exemplo, possui um sentido vago, impreciso, e é largamente empregado na língua falada popular para substituir outros substantivos, não raro obscurecendo o sentido do enunciado. Que vocábulo seria mais adequado em seu lugar?

Urbano, sobre a palavra "coisa", assim se refere:

entendemos que essa palavra é, às vezes, praticamente insubstituível, ao menos dentro da economia e fugacidade que caracterizam a comunicação de modo geral e a popular de modo particular." (URBANO, 2011, p. 82-83)

Vejamos o seguinte exemplo de Quarto de despejo:

Na enchente de 49 morreu o Pedro Cardoso, filho de Dona Ida. Quando eu soube que o Pedrinho havia morrido afogado pensei na decepção que teve a sua avó que pedia água, água, bastante água para matar os favelados e veio água e matou-lhe o neto. É para ela compreender que Deus é sóbrio. É o advogado dos humildes. Os pobres são criaturas de Deus. E o dinheiro é um metal criado e valorizado pelo homem. (...) Se Deus avisasse a Dona Ida que ela por não dar água ia perder o seu filho para sempre, creio que ela estaria nos dando água até hoje. O Pedro pagou em holocausto o orgulho de sua avó. E a maldade de sua mãe. É assim que Deus repreende. (p. 57, linhas 24-35)

No trecho em questão, o vocábulo "holocausto" é empregado em sentido diverso do original, embora não constitua um traço estilístico. De acordo com Houaiss, holocausto significa "sacrifício" ou "expiação", em alusão aos sacrifícios de animais praticados pelos antigos hebreus, quando um animal era queimado em um altar de pedras. No exemplo do Quarto, a narradora atribui à morte trágica de um garoto em uma enchente o 
significado de holocausto, como se fosse uma morte expiatória. Entretanto, o próprio uso do vocábulo entra em conflito com a afirmação seguinte de que "é assim que Deus repreende", visto que os "holocaustos" propriamente ditos não eram "castigos de Deus", mas sacrifícios oferecidos de forma ritualística. Há, portanto, uma contraposição entre o real sentido do vocábulo "holocausto" e o sentido de "castigo" que o enunciado sugere.

\subsection{4 - Metáforas e comparações concretas}

Embora a metáfora não seja um fato estilístico exclusivo de uma modalidade específica da língua, a língua falada é pródiga em construções metafóricas. As metáforas da língua falada são metáforas conceituais de uso popular, tanto na forma quanto no conteúdo (do tipo $A$ é B).

De acordo com Azeredo, a metáfora consiste

no emprego de palavras ou expressões convencionalmente
identificadas com um dado domínio de conhecimento para
verbalizar experiências conceptuais de outro domínio. (...) A
metáfora é um recurso de expressão amplamente usado no
discurso cotidiano, por mais que seja tradicionalmente tratado
como característico da linguagem da poesia." (AZEREDO, 2008, p.
418 , grifos nossos)

Reconhecendo o caráter oral de muitas metáforas quotidianas, o mesmo autor cita os seguintes exemplos:

colher resultados; ruminar pensamentos; quebrar o silêncio; esses políticos são velhas raposas; aquela lesma levou duas horas para escrever um simples bilhete; o motorista rosnou um palavrão; aplicou no paciente uma dose cavalar de antibiótico. (id., p. 418419, grifos do autor)

Depreendemos, a partir dos exemplos citados pelo autor, que a grande maioria das metáforas de uso cotidiano se cristalizaram pelo uso, tornando-se praticamente imperceptíveis como tais.

A língua é essencialmente metafórica, e as metáforas aparecem com bastante vitalidade no discurso quotidiano. Podemos citar como exemplo a seguinte manchete: "Neymar apresenta visual de filé de borboleta após 
cirurgia: 'Perdi 5 kh'". (Site Foxsports, 19/07/2013)

A lexia "filé de borboleta" é uma metáfora interessante e possui um caráter informal. Seu sentido é o de uma pessoa muito magra, e estabelece uma relação de sentido entre a magreza do atleta e o aspecto delgado de uma borboleta, que é um inseto pequeno. Há, portanto, a identificação de um traço semântico comum entre os dois domínios.

Outro exemplo interessante é "B.O. ${ }^{28 "}$ (sigla de Boletim de Ocorrência). Embora B.O. seja o registro de um fato policial, documento lavrado em uma delegacia de polícia, na linguagem comum é empregado metaforicamente como sinônimo de problema ou confusão. Trata-se de uma metáfora concreta, de estrutura simples, em que há uma transposição de sentido: sendo O BO (documento) fruto de uma circunstância adversa, seu sentido se aplica não apenas ao documento oficial mas a qualquer tipo de contrariedade cotidiana, mesmo que não seja caso de polícia.

No esteio da metáfora, também ocorrem na língua falada popular comparações simples, muito semelhantes à metáfora: "pobre como Jó", "alto como um poste", "surdo como uma porta", "feia como uma bruxa", etc.

Embora seja difícil precisar a frequência de tais expressões, sentimos, na condição de usuários da língua, que muitas constituem chavões, clichês ou frases feitas. Apesar dessa dificuldade de caracterização, as metáforas e as comparações concretas são bastante sugestivas pela simplicidade e evocação de imagens quotidianas, o que também não deixa de ser um aspecto da variedade popular.

\subsection{5 - Vocabulário de uso vulgar}

28 Recentemente, escutamos uma mulher dizer o seguinte: "Não peço ajuda pra ninguém. Meus B.O. eu resolvo tudo sozinha." Evidentemente a falante em questão não se referia a um Boletim de Ocorrência literal, mas conotativamente a os seus problemas pessoais. 
Por vocabulário de uso vulgar entendemos o vocabulário considerado grosseiro por uma dada comunidade, geralmente de domínio semântico da sexualidade e da fisiologia humana e/ou animal. O caráter "baixo" dado ao referente é, por extensão, aplicado também ao vocábulo que o designa, constituindo um tabu linguístico.

Até mesmo os vocábulos não obscenos que possuem o mesmo sema de sexualidade e fisiologia também são evitados e substituídos por formas consideradas eufêmicas. Nomes de partes do corpo humano (por exemplo, designações tais como "pênis", "vagina", "vulva", "escroto", "testículos", "pequenos lábios", "grandes lábios", "clitoris", "nádegas", "ânus") e atos fisiológicos (urinar, defecar, menstruar) são evitados por muitos falantes, mesmo que não sejam vocábulos de uso grosseiro. Consequentemente, os vocábulos de uso mais informal para algumas dessas partes do corpo humano ou ao metabolismo são considerados de uso grosseiro ou obsceno. Até o nome da especialidade médica "proctologia", um vocábulo culto sem dúvida, é evitado e empregado muitas vezes em tom humorístico.

Assim, curiosamente, à medida que os vocábulos mais "técnicos" possuem uma relativa interdição social, seus correspondentes informais são de uso ainda mais restrito.

Se um vocábulo como "pênis", por exemplo, é substituído na linguagem infantil por formas consideradas eufêmicas, na linguagem de uso vulgar, o uso criou dezenas de vocábulos obscenos como sinônimos de pênis, a maioria de caráter metafórico, relacionando o órgão sexual masculino a formas pontiagudas, vistas como formas semelhantes. Daí acepções obscenas como "mandioca", "tarugo", "pau", "espingarda", etc.

O ato sexual é chamado, vulgarmente, de "transar", "afogar o ganso", "molhar o biscoito", "agasalhar o croquete", "trocar o óleo", "foder", "dar uma foda", entre diversos sinônimos. No mesmo domínio semântico, a masturbação também é designada por diversos sinônimos de uso vulgar ("descabelar o palhaço", "cinco contra um"), assim como os 
vocábulos referentes à homossexualidade, tais como "morder a fronha" e "queimar a rosca" (praticar o coito anal), "viado", "fruta", "frutinha", "bicha", "bichona" (homossexual masculino), "sapatão" (lésbica), "paneleiro" (homossexual masculino, em Portugal), etc.

O mesmo acontece com os atos fisiológicos, também substituídos disfemicamente por outros de uso considerado grosseiro. Urinar cede lugar a "mijar", "dar uma mijada", "tirar água do joelho", e "defecar" cede lugar a "cagar", "soltar um barrão", "borrar-se", entre outros. O mesmo acontece com o produto da excreção: urina é chamada de "xixi", e as fezes, ou excrementos, são chamados de "bosta", "cocô" ou "merda". O ciclo menstrual é vulgarmente chamado de "chico", "pingadeira", "volta da lua" etc.

Em alguns casos, lexemas como "cu" (ânus) "caralho", "merda", "bosta", etc, são empregados de forma interjecional em situação de contrariedade ou como formas de insulto, tais como "ir à merda", "tomar no cu", "cuzão" etc.

Menos numerosas em Quarto de despejo, mas não menos significativas, aparecem na obra lexias de uso vulgar (obscenas, escatológicas ou injuriosas), algumas sugeridas por reticências na publicação do livro, mas presentes no texto original. Na medida do possível, optamos pela versão de Meu estranho diário. Em alguns casos, o trecho em análise não apresenta paralelo para confronto, o que nos impede de afirmar categoricamente que todas as reticências sejam fruto do processo editorial.

Embora tenhamos classificado todos sob a designação ampla de "vulgares", alguns são mais agressivos e obscenos que outros. A este respeito, servimo-nos das oportunas reflexões de Preti:

pode-se dizer, em geral, que os vocábulos obscenos vêm sempre associados a certa classe de falantes menos cultos, exceto quando são empregados para a função injuriosa ou blasfematória, ocasião em que se perde essa relação. $E$, nessa função, os termos grosseiros coincidem com um tom mais forte, que lhes acentua 0 
caráter agressivo, tornando-se um veículo de expressão de sentimentos, muito mais do que de comunicação. (PRETI, 2010, p. 83)

São todos vocábulos considerados grosseiros, independentemente de sua temática: referem-se à sexualidade, à fisiologia humana e animal, e exprimem aquilo que a sociedade letrada considera de mau gosto ou desagradável.

Conforme o mesmo autor reconhece, "o principal problema para a análise e classificação da linguagem grosseira ou obscena estaria em definir o que consiste a obscenidade e grosseria" (op. cit., p. 85). Ainda acrescenta:

Em geral, pode-se dizer que um dos índices do vocábulo grosseiro e obsceno é a sua preferência a uma vida sexual quase sempre deformada, que se fundamenta nos comportamentos de exceção, nos vícios e exageros eróticos. (...) além desses tabus e bem anteriormente a eles, em nível profundo, o sexo, a defecação e a podridão são arquétipos de um sistema de não-valor, de negação de todo valor. (op. cit., p. 85-86)

Novamente nos deparamos com fatores extralinguísticos para a determinação do registro. É um balizamento precário, mas aponta um caminho.

4.5.6 - Vocabulário de uso injurioso

A linguagem injuriosa é a linguagem usada por um falante para ofender, insultar ou debochar de outrem, quer em interação ou não. Algumas expressões, mesmo ditas fora de um contexto específico, são reconhecidamente ofensivas. Outras, porém, só podem ser caracterizadas como tal dentro de um contexto de enunciação. Vocábulos usados para injuriar ou expressar emoções violentas podem não ter a mesma carga semântica em outros contextos.

Palavras como preta, negra e fidida, isoladamente não seriam expressões injuriosas, mas o são dentro do contexto da narrativa de Quarto de despejo. Convém lembrar que, nesses casos, as expressões não 
ocorrem na narração, mas no discurso direto, quer com a própria narradora como personagem em interação, quer com outros personagens entre si.

\subsection{7 - Vocabulário de uso afetivo: os hipocorísticos e os apelidos}

O léxico afetivo ou familiar, empregado por um falante em situação de intimidade em interação com outros falantes com quem tem relações de parentesco ou afeto pode se formar de vários modos. Entre várias possibilidades, destacamos o uso de apelidos e hipocorísticos na enunciação de nomes próprios.

Marca típica da linguagem afetiva, familiar e/ou infantil, o hipocorístico é constituído pela deformação do significante de substantivos, reduplicação de sílabas ou combinações de sílabas iniciais de nomes compostos, bem como pelo acréscimo de sufixos (de diminutivo ou aumentativo). O hipocorístico é, segundo Câmara Jr,

em sentido lato, qualquer palavra criada por afetividade com intenção de carinho. (...) Em sentido estrito, o hipocorístico é uma alteração do prenome para designar carinhosamente o indivíduo no meio familiar. (CÂMARA JR, 1964, p. 183, grifos nossos)

São hipocorísticos formas de uso como "Cida" (Aparecida), "Tonico" (Antônio), "Zé" (José), "Zuza" (José), "Cacá" (Carlos), "Nando" (Fernando), "Rô" (Rosana), "Bia" (Beatriz), "Lu" (Luciana), "Síl" (Silvana), "Ed" (Eduardo, Edmar), entre muitos outros. Não apenas os nomes próprios se enquadram nesta categoria, como também formas como "mamãe" (mãe), "papai" (pai), "mainha" (mãe), "painho" (pai), benzinho, mano (irmão) etc.

O caráter oral dos hipocorísticos pode ser depreendido do que diz Coutinho:

29 As formas "mainha" e "painho", são largamente empregadas na região NE do Brasil, não apenas na linguagem infantil ou por falantes do povo. Já tivemos a oportunidade de ouvir falantes cultos (com formação universitária, portanto) empregar tais formas com absoluta naturalidade. Tomamos nota desse uso por uma enfermeira de 40 anos (Recife, PE) e por uma advogada de 32 anos (Natal, RN) em 2012. 
Entre os nomes de pessoas, alguns tiveram tratamento especial na boca das crianças e das pessoas que delas cuidam, de que resultou sofrerem, às vezes, profundas modificações. (...) no primeiro caso, eles se explicam por insuficiência da pronúncia infantil; no segundo, servem para exprimir carinho. Nessa mutilação, observase que há geralmente conservação da sílaba tônica: Quim (Joaquim), Zé (José); ou das sílabas mais importantes do nome: Tônio (Antônio), Tião (Sebastião). Mas há também casos de manutenção, no hipocorístico, de sílabas átonas do nome: Filó (Filomena), Guiô (Guiomar), Beá (Beatriz). Um processo comumente usado na formação de hipocorísticos é o redobro: Zezé, Lulu, Quinquim. (COUTINHO, 1976, p. 222-223, grifos nossos)

Esse "tratamento especial" ocorre não só na "boca das crianças", mas também na "boca" dos falantes de todas as faixas etárias ou estratos sociais em situação de familiaridade e informalidade.

No mesmo campo semântico dos hipocorísticos estão os apelidos ou alcunhas, também de largo emprego na língua falada. Os chamados "apelidos" ou "alcunhas" podem se formar de maneiras diversas e variáveis de acordo com o contexto. Borba assim os define: "ALCUNHA sf. apelido; cognome, geralmente depreciativo." (BORBA, 2004, p. 45)

Podem facilmente ser confundidos com os hipocorísticos por apresentarem, em alguns casos, idêntica morfologia, formados por diminutivo ou aumentativo, por exemplo, e por também expressarem afetividade em algumas circunstâncias.

Entretanto, como percebemos em diversos contextos, o apelido não se forma a partir do nome próprio, mas expressa uma característica do referente, admitindo um uso mais amplo. Enquanto os hipocorísticos são formados a partir de um significante, o apelido é formado a partir de um significado, tomando como referência fatores extralinguísticos, geralmente atributos físicos ou psicológicos do referente. Formas como "Gordo", "Negão", "Alemão" ou as antonomásias "Terra da Garoa" (São Paulo), "Veneza Brasileira" (Recife) e "Cidade Maravilhosa" (Rio de Janeiro) são apelidos $^{30}$.

30 Escutamos no Rio de Janeiro o apelido jocoso "São João do Meriticídio" em referência ao município de São João do Meriti. Formada por derivação sufixal com a posposição do 
Assim, por exemplo, "magrão" é um apelido e não é um hipocorístico, pois não toma como referência um nome próprio em particular (um significante) e sim o atributo físico de qualquer indivíduo do sexo masculino (um significado).

sufixo - cídio ("ação de quem mata ou o seu resultado"), "meriticídio" é uma criação bastante expressiva, que alude de forma irreverente aos altos índices de criminalidade não só do município propriamente dito como também de toda a região da Baixada Fluminense. 
TERCEIRA PARTE - ANÁLISE DO CORPUS 


\section{CAPÍTULO 5 - USOS VOCABULARES DE QUARTO DE DESPEJO}

Embora sejam imprescindíveis critérios mínimos para a caracterização de itens lexicais específicos como populares (tendencialmente + orais) ou cultos (tendencialmente + escritos), conforme expusemos no capítulo precedente, reiteramos que não se trata de critérios rígidos, estanques e definitivos.

Também, voltamos a reconhecer a precariedade de tais critérios, visto que se trata de um fenômeno menos linguístico do que social. Entendemo-los como critérios preliminares, interligados e não excludentes. De modo geral, o que pretendemos demonstrar é que há um número bastante expressivo de vocábulos de nível popular que constituem um traço de língua falada no texto escrito de Quarto de despejo.

Partindo da premissa (exposta e discutida no capítulo 4) de que os vocábulos e expressões populares são traços de língua falada porquanto tendencialmente orais (e, logo, - escritos), procederemos à análise de algumas ocorrências no texto de Quarto de despejo.

A problemática dos critérios para o uso "popular" e "culto" do vocabulário imputamos, em grande parte, ao caráter difuso da teoria em revista.

Os vocábulos de uso popular ocorrem tanto na voz da narradora (alguns em menor grau) quanto na voz dos personagens (outros em maior grau). Os personagens atuam na narrativa por meio de discurso direto, com emprego de verbos dicendi e travessões. Ressalte-se que, nas ocasiões em que a narradora dá voz a outrem, inclui-se como personagem em interação com os outros moradores da favela ou com pessoas próximas.

Entre as ocorrências na voz narrativa, podemos citar basicamente os vocábulos de nível popular, gírios, vocábulos ligados ao universo do povo ou a um contexto popular, vocábulos com imprecisão de sentido ou 
sentido genérico e o largo emprego de hipocorísticos. Na voz dos personagens também ocorrem vocábulos do mesmo nível de registro da narradora, mas também um grande número de vocábulos de cunho injurioso ou obsceno.

No capítulo 4 elencamos várias características do vocabulário de uso popular presentes no contexto da obra: vocábulos de uso informal, vocábulos gírios, vocábulos de uso vulgar, vocábulos de uso injurioso e vocábulos de uso afetivo.

A partir do próximo tópico vamos analisar parte dessas ocorrências em Quarto de despejo.

Reiteramos que se trata de uma análise por amostragem, sem a pretensão de quantificarmos cem por cento das ocorrências. Acreditamos que os exemplos em revista sirvam para demonstrar os usos vocabulares da narradora.

Ao lado desses itens lexicais de traço - escrito e + falado, há muitos outros, de feição culta, advindos da língua escrita de uso formal.

Os itens lexicais analisados neste trabalho foram selecionados conforme se pode visualizar nas seguintes tabelas a seguir.

Ressalte-se que as lexias de traço popular são consideradas em contexto, isto é, que seu caráter oral é depreendido de seu significado dentro do contexto e não isoladamente.

Tabela 07 - Quarto de Despejo - Lexias de traço popular

\begin{tabular}{|c|c|c|c|c|}
\hline No. $^{\circ}$ & Lexia & Ano & $\begin{array}{c}\text { Data da } \\
\text { entrada }\end{array}$ & $\begin{array}{c}\text { Contexto } \\
\text { (página/linhas) }\end{array}$ \\
\hline 01 & Angelina Preta & 1958 & 29 de junho & $77: 15-19$ \\
\hline 02 & apetite de leão & 1958 & 16 de julho & $92: 30-34$ \\
\hline 03 & aposentado & 1959 & 08 de janeiro & $145: 29-34$ \\
\hline 04 & arranjar (mulher) & 1959 & 08 de janeiro & $145: 29-34$ \\
\hline 05 & arrepiar os cabelos & 1958 & 10 de julho & $90: 13-18$ \\
\hline 06 & bacalhau (feder) & 1958 & 8 de novembro & $131: 07-13$ \\
\hline
\end{tabular}




\begin{tabular}{|c|c|c|c|c|}
\hline 07 & barracão & 1955 & 27 de julho & $28: 23-25$ \\
\hline 08 & barraco & 1959 & 18 de junho & 166: $28-29$ \\
\hline 09 & bate-fundo (s) & 1958 & $\begin{array}{c}28 \text { de maio } \\
15 \text { de agosto }\end{array}$ & $\begin{array}{l}\text { 46: } 12-16 \\
109: 20-22\end{array}$ \\
\hline 10 & bobagem (fazer) & 1959 & 28 de julho & $176: 14-24$ \\
\hline \multirow[t]{2}{*}{11} & \multirow[t]{2}{*}{ bosta } & \multirow[t]{2}{*}{1958} & 4 de julho & $80: 33-81: 03$ \\
\hline & & & 8 de agosto & 105: $22-24$ \\
\hline 12 & cacete & 1958 & 8 de junho & 57: $14-23$ \\
\hline 13 & cana & 1958 & 28 de junho & $74: 30-75: 05$ \\
\hline 14 & carteira (bater) & 1958 & 06 de julho & 82: $11-14$ \\
\hline 15 & Chiclé & 1958 & 8 de julho & 85: $14-24$ \\
\hline 16 & chico & 1959 & 28 de julho & 176: $14-24$ \\
\hline 17 & $\begin{array}{c}\text { chiqueiro (de São } \\
\text { Paulo) }\end{array}$ & 1959 & 6 de julho & 170: $01-25$ \\
\hline 18 & Chiquinha & 1958 & 1 de julho & 79:06-09 \\
\hline 19 & cidade esquisita & 1958 & 10 de julho & 90: $13-22$ \\
\hline \multirow{4}{*}{20} & \multirow[t]{4}{*}{ coisa } & 1955 & 20 de julho & 23: $06-09$ \\
\hline & & 1958 & 30 de maio & $47: 23-32$ \\
\hline & & 1958 & 12 de novembro & $131: 28-132: 3$ \\
\hline & & 1959 & 3 de fevereiro & 152: $07-11$ \\
\hline 21 & comer $\mathrm{m} . .$. & 1959 & 31 de julho & 177: $01-07$ \\
\hline 22 & cortiço & 1955 & 22 de julho & $26: 23-26$ \\
\hline 23 & dar & 1959 & 6 de julho & 170: $01-25$ \\
\hline 24 & Dentista & 1958 & 8 de julho & 85: $14-24$ \\
\hline 25 & embrulhar & 1959 & 8 de junho & 162: $19-25$ \\
\hline 26 & encrenca & 1958 & 17 de julho & 93: $01-06$ \\
\hline 27 & espelunca & 1959 & 08 de agosto & 179: 03-06 \\
\hline 28 & fidida & 1955 & 24 de julho & 28: $07-11$ \\
\hline 29 & firme & 1958 & 11 de dezembro & 137: $12-16$ \\
\hline 30 & foda (dar uma) & 1958 & 3 de novembro & 127: $08-10$ \\
\hline 31 & foder & 1958 & 21 de novembro & 134: $03-07$ \\
\hline 32 & fresco & 1959 & 9 de junho & 164: $18-28$ \\
\hline 33 & fuá (dos diabos) & 1959 & 10 de maio & 159: $23-29$ \\
\hline 34 & gabinete (do Diabo) & 1959 & 6 de julho & 170: $01-25$ \\
\hline 35 & juiz (fome serve de) & 1958 & 3 de junho & $53: 32-33$ \\
\hline 36 & lenga-lenga & 1959 & 03 de julho & 169: $29-34$ \\
\hline 37 & lixeira & 1958 & 21 de julho & 97:06-11 \\
\hline 38 & maloca $(\mathrm{s})$ & 1955 & 18 de julho & 21: $16-29$ \\
\hline 39 & mamãe & 1958 & 13 de maio & $32: 14-16$ \\
\hline 40 & manda-chuva & 1958 & 15 de junho & $62: 33-63: 11$ \\
\hline 41 & $\begin{array}{l}\text { mão em mão } \\
\text { (passar de) }\end{array}$ & 1958 & 22 de outubro & 122: $13-25$ \\
\hline 42 & merda (comer) & 1959 & 31 de julho & 177: 01-07 \\
\hline 43 & nojenta & 1959 & 09 de junho & 164: $18-28$ \\
\hline 44 & norte & 1958 & 28 de maio & $46: 32-35$ \\
\hline
\end{tabular}




\begin{tabular}{|c|c|c|c|c|}
\hline \multirow[t]{3}{*}{45} & \multirow[t]{3}{*}{ nortista } & 1958 & 28 de maio & $46: 32-35$ \\
\hline & & 1958 & 13 de agosto & 106: $27-29$ \\
\hline & & 1958 & 24 de dezembro & 139: $28-31$ \\
\hline 46 & ordinária & 1958 & 21 de julho & 97: 06-11 \\
\hline 47 & pobre como rato & 1958 & 23 de setembro & 119: $11-13$ \\
\hline 48 & porcaria (fazer) & 1958 & 26 de setembro & 120: $04-10$ \\
\hline 49 & professora & 1958 & 10 de maio & $31: 12-15$ \\
\hline 50 & puta que (te) pariu & 1959 & 27 de junho & 168: 01-09 \\
\hline 51 & puto & 1959 & 09 de junho & 164: $18-28$ \\
\hline 52 & quarto de despejo & 1958 & 27 de dezembro & 141: $14-25$ \\
\hline 53 & show (dar um) & 1958 & 8 de julho & $84: 25-32$ \\
\hline 54 & sova (dar uma) & 1958 & 1 de setembro & 116: 07-09 \\
\hline 55 & sucursal do inferno & 1959 & 7 de maio & 158: $08-12$ \\
\hline 56 & sururu & 1958 & 5 de junho & 162:03-08 \\
\hline 57 & Tina da Dona Mulata & 1958 & 8 de junho & 57: $14-23$ \\
\hline 58 & tomar no... & 1959 & 18 de junho & 166: $34-167: 3$ \\
\hline 59 & tuberculosa & 1955 & 24 de julho & 27: $28-28: 02$ \\
\hline 60 & úlcera & 1958 & 7 de julho & $84: 18-24$ \\
\hline \multirow[t]{5}{*}{61} & \multirow[t]{5}{*}{ vagabunda } & 1955 & 18 de julho & $21: 16-29$ \\
\hline & & 1958 & 11 de junho & 59: $16-20$ \\
\hline & & 1958 & 21 de julho & 97: $06-11$ \\
\hline & & 1959 & 09 de junho & 164: $18-28$ \\
\hline & & 1959 & 18 de junho & 166: $33-38$ \\
\hline 62 & vagabundar & 1958 & 27 de agosto & 115: $15-19$ \\
\hline 63 & Valdemar Espadela & 1958 & 19 de julho & 94: $22-27$ \\
\hline 64 & $\begin{array}{c}\text { vida mansa } \\
\text { (estar com a) }\end{array}$ & 1958 & 28 de julho & 101: 01-03 \\
\hline 65 & Vítor Franquistém & 1958 & 19 de julho & 94: $22-27$ \\
\hline 66 & zé povinho & 1958 & 28 de maio & $46: 12-16$ \\
\hline 67 & zé qualquer & 1958 & 21 de maio & 41: 07-12 \\
\hline 68 & Zefa & 1955 & 18 de julho & 18: $08-11$ \\
\hline 69 & Zuza & 1958 & 22 de junho & 68: $30-69: 09$ \\
\hline
\end{tabular}

Tabela 08 - Quarto de despejo - Lexias de traço culto

\begin{tabular}{|c|c|c|c|c|}
\hline$N^{\circ}$. & Lexia & Ano & $\begin{array}{c}\text { Data da } \\
\text { entrada }\end{array}$ & $\begin{array}{c}\text { Contexto } \\
\text { (página/linhas) }\end{array}$ \\
\hline 70 & benéfico & 1955 & 19 de julho & $22: 17-19$ \\
\hline 71 & contemplar & 1955 & 22 de julho & $27: 01-02$ \\
\hline 72 & contingência & 1955 & 19 de julho & $19: 26-28$ \\
\hline
\end{tabular}




\begin{tabular}{|l|c|c|c|c|}
\hline 73 & instigar & 1955 & 24 de julho & $28: 10-11$ \\
\hline 74 & meretriz & 1955 & 19 de julho & $20: 28-32$ \\
\hline 75 & pungente & 1955 & 20 de julho & $24: 04-06$ \\
\hline 76 & rascoa & 1955 & 19 de julho & $22: 17-19$ \\
\hline 77 & renegar & 1955 & 19 de julho & $20: 28-32$ \\
\hline 78 & resoluta & 1955 & 19 de julho & $19: 26-28$ \\
\hline 79 & rumor & 1955 & 17 de julho & $15: 30-31$ \\
\hline 80 & sapiência & 1955 & 20 de julho & $22: 36-23: 01$ \\
\hline
\end{tabular}

Tabela 09 - Meu Estranho Diário - Lexias de traço popular

\begin{tabular}{|c|c|c|c|c|}
\hline$N^{\circ}$. & Lexia & Ano & $\begin{array}{c}\text { Data da } \\
\text { entrada }\end{array}$ & $\begin{array}{c}\text { Contexto } \\
\text { (página/linhas) }\end{array}$ \\
\hline 81 & buceta & 1958 & 17 de novembro & $77: 33-78: 20$ \\
\hline 82 & buceta (chupar) & 1958 & 17 de novembro & $77: 33-78: 20$ \\
\hline 83 & cacete & 1958 & 16 de novembro & $71: 32-72: 03$ \\
\hline 84 & cagar & 1958 & 12 de novembro & $65: 20-24$ \\
\hline 85 & chupador & 1958 & 17 de novembro & $77: 33-78: 20$ \\
\hline 86 & cupincha & 1958 & 2 de novembro & $41: 23-28$ \\
\hline 87 & merda (marca) & 1958 & 19 de novembro & $82: 17-25$ \\
\hline 88 & muamba & 1958 & 19 de novembro & $81: 06-07$ \\
\hline
\end{tabular}

Tabela 10 - Meu Estranho Diário - Lexias de traço culto

\begin{tabular}{|c|c|c|c|c|}
\hline No. & Lexia & Ano & $\begin{array}{c}\text { Data da } \\
\text { entrada }\end{array}$ & $\begin{array}{c}\text { Contexto } \\
\text { (página/linhas) }\end{array}$ \\
\hline 89 & atrabiliosa & 1958 & 25 de novembro & $95: 25-96: 02$ \\
\hline 90 & clã & 1958 & 22 de novembro & $93: 03-05$ \\
\hline 91 & dissipar & 1958 & 30 de novembro & $103: 29-30$ \\
\hline 92 & infausto consórcio & 1958 & 4 de dezembro & $115: 01-03$ \\
\hline 93 & infortúnio & 1958 & 25 de novembro & $95: 25-96: 02$ \\
\hline 94 & letárgica & 1958 & 07 de novembro & $54: 11-13$ \\
\hline 95 & notívaga & 1958 & 30 de novembro & $103: 29-30$ \\
\hline 96 & núcleos sórdidos & 1958 & 4 de dezembro & $115: 18-22$ \\
\hline 97 & prófugo & 1958 & 22 de novembro & $93: 03-05$ \\
\hline 98 & tenacidade & 1958 & 2 de dezembro & $105: 30-34$ \\
\hline 99 & vergel & 1958 & 27 de novembro & $99: 01-03$ \\
\hline
\end{tabular}


5.1 Traços orais do léxico de Quarto de despejo

5.1.1 - Vocábulos de uso informal: a caracterização do quotidiano das pessoas do povo

Em Quarto de despejo há um número considerável de itens lexicais ligados semanticamente entre si e que retratam a vida quotidiana de pessoas humildes.

Tais vocábulos parecem circunscrever-se à modalidade oral, sendo, portanto, tendencialmente menos usados na língua escrita de uso formal.

Nas duas primeiras entradas notamos, na voz da narradora, o uso de "Zé qualquer" e "Zé povinho", lexias compostas que possuem o mesmo significado de pessoa reles, comum, sem importância.

No primeiro caso, a narradora se refere por "Zé qualquer" a um indivíduo morto, cujo nome é desconhecido. No segundo, a expressão "Zé povinho" é empregada depreciativamente, referindo-se aos moradores da favela coletivamente:

21 de maio de 1958 (...) No outro dia encontraram o pretinho morto. Os dedos do seu pé abriram. O espaço era de vinte centímetros. Ele aumentou-se como se fosse de borracha. Os dedos do pé parecia leque. Não trazia documentos. Foi sepultado como um Zé qualquer. Ninguém procurou saber seu nome. Marginal não tem nome. (p. 41, linhas 07-12)

28 de maio de 1958 (...) Quando começa as brigas os favelados deixam seus afazeres para presenciar os bate-fundos. De modo que quando a mulher sai correndo nua é um verdadeiro espetáculo para o Zé Povinho. (p. 46, linhas 12-16)

A expressão "Zé qualquer" não é empregada depreciativamente, mas retrata a condição anônima de um indivíduo sem teto e faminto, que sequer é chamado pelo nome. É um "Zé qualquer", é um "pretinho", mais um que morre em consequência da miséria. 
Zé povinho, por outro lado, possui valor depreciativo e ressalta não o anonimato das pessoas, mas sua condição de plebe ou populacho.

Essas pessoas, vistas por uma ótica extremamente desfavorável pela narradora, fazem coisas "de arrepiar os cabelos" (chocantes), "dão show", fazem "fuá", tudo em consonância com sua condição de pessoas "incultas":

8 de julho de 1958 Eu estava indisposta, deitei cedo. Despertei com a algazarra que fazia na rua. Não dava para compreender o que diziam porque todos falavam ao mesmo tempo e era muitas vozes reunidas. Vozes de todos os tipos. Eu queria levantar para pedir-Ihe que deixasse o povo durmir. Mas percebi que ia perder tempo. Eles já estavam alcoolizados. A Leila deu o seu show. E os seus gritos não deixou os visinhos dormir. (p. 84, linhas 25-32)

10 de julho de 1958 (...) Fui buscar uma lata de água e uma senhora estava lamentando:

- Se eu fosse jovem eu não residia nesta favela nem um dia. Mas eu já sou velha. E velho não se governa.

Aqui nessa favela a gente vê coisa de arrepiar os cabelos. (p. 90, linhas 13-18)

10 de maio de 1959 Eu não dormi porque o vizinho tocou o rádio toda a noite. E a L. fez um fuá dos diabos. Ela estava dormindo com o Valdemar quando o Arnaldo chegou. Era 2 horas. O Arnaldo dizia:

Vai embora, Valdemar! A negra é minha!

O Valdemar respondia:

A negra é nossa! Eu cheguei primeiro. (p. 159, linhas 23-29)

Ao contrário de Zé qualquer e Zé povinho, o políticos são indivíduos poderosos, são os "manda-chuva", aqueles que têm "a vida mansa".

15 de junho de 1958 ...Fui comprar carne, pão e sabão. Parei na banca de jornais. Li que uma senhora e três filhos havia suicidado por encontrar dificuldade de viver $(\ldots)$ Pobre mulher! Quem sabe se de há muito ela vem pensando em eliminar-se, porque as mães tem muito dó dos filhos. Mas é uma vergonha para uma nação. Uma pessoa matarse porque passa fome. E a pior coisa para uma mãe é ouvir esta sinfonia:

- Mamãe, eu quero pão! Mamãe, eu estou com fome! Penso: será que ela procurou a Legião Brasileira ou Serviço Social? Ela devia ir nos palácios falar com os manda-chuva. (p. 63, linhas ) 
28 de julho de 1958 (...) Bem: vamos deixar o Dr. Adhemar paz porque ele está com a vida mansa. Não passa fome. Não come nas latas de lixo igual os pobres. (p. 101, linhas 01-03)

Há um nítido contraste entre um "Zé qualquer" e um "mandachuva", membros de polos extremos da sociedade, retratados em Quarto de despejo. Um é um infeliz que morre em consequência de comer restos estragados, e o outro é o político, o homem forte e poderoso, que "está com a vida mansa", sem preocupações e usufruindo fartura.

Vejamos mais quatro entradas, em que aparecem as expressões "ter um apetite de leão" (estar faminto), "dar uma sova" (bater em alguém), "feder bacalhau" ("exalar extremo mau cheiro por falta de banho"), "arranjar mulher" (conquistar uma parceira para relações sexuais) e "aposentado" (no sentido de homem que não tem mais vida sexual ativa):

16 de julho de 1958 .... Não havia papel nas ruas. Passei no Frigorífico. Havia jogado muitas linguiças no lixo. Separei as que não estava estragadas. (...) Eu não quero enfraquecer e não posso comprar. E tenho um apetite de leão. Então recorro ao lixo. (p. 92, linhas 30-34)

1 de setembro de 1958 .... Eu fui na feira, comprei uma laranja. Cheguei em casa e a Vera estava no quintal. Dei-Ihe uma sova. (p. 116, linha 07-09)

8 de novembro de 1958 (...) Fiz arroz e puis água esquentar para eu tomar banho. Pensei nas palavras da mulher do Policarpo que disse que quando passa perto de mim eu estou fedendo bacalhau. Disse-Ihe que eu trabalho muito, que havia carregado mais de 100 quilos de papel. E estava fazendo calor. E o corpo humano não presta.

Quem trabalha como eu tem que feder. (p. 131, linhas 07-13)

08 de janeiro de 1959 ...Encontrei com o motorista que veio despejar a serragem aqui na favela. Convidou-me para entrar no caminhão. O motorista loiro perguntou-me se aqui na favela é fácil arranjar mulher. E se ele podia ir no meu barracão. $O$ motorista disse-me que ele ainda estava em forma. O ajudante dizia que o motorista já havia aposentado. (p. 145, linhas 29-34)

Apesar de parecer empiricamente observável que tais vocábulos são tendencialmente mais falados do que escritos, é difícil estabelecer com absoluta precisão que constituam traços orais. Enfatizamos que, por 
serem itens lexicais de uso limitado na escrita formal, ficam restritos à esfera da língua falada.

Da mesma forma, "apetite de leão", empregado pela narradora para se referir à própria fome, assim como leões comem muita carne de caça após um período sem alimentação, intensifica o sentido de sua afirmativa: não tem simplesmente "fome", mas "apetite de leão".

Ao registrar em determinada passagem que estava sem banho, a narradora usa a expressão "feder bacalhau", que reforça a ideia de falta de banho pela similaridade com o mau cheiro exalado por peixes não frescos.

As duas ocorrências de 08 de janeiro de 1959 mostram que alguns vocábulos de sema sexual podem perder os traços de grosseria e agressividade e ser empregados de maneira informal. "Arranjar mulher" e "aposentado" possuem temática sexual, mas não são agressivos e até conferem um toque de humor ao enunciado.

Há outras ocorrências do tipo em Quarto de despejo. De modo geral, o que nos parece lícito concluir é que o uso desse vocabulário reforça a condição sociocultural da narradora, bem como a força que o ambiente exerce sobre a sua narrativa.

5.1.2 - A gíria como uma das representações da língua falada em Quarto de despejo

Carolina era uma pessoa de quase nenhuma instrução formal, embora fosse muito esforçada e tenha tido intensas práticas de leitura. Vivia no ambiente da favela, em interação com indivíduos de condição socioeconômica semelhante.

Que outro ambiente projetaria com tamanha força a vivacidade de seu vocabulário sobre a narração de Carolina? 
Considerando como gírios os vocábulos registrados por Antenor Nascentes (AN), Manuel Viotti (MV) e J. B. Serra e Gurgel (SG) em seus respectivos dicionários de gíria, bem como os presentes no Dicionário contemporâneo de Caldas Aulete (CA), postulamos que a abundante ocorrência de vocábulos gírios em Quarto de despejo reforça a nossa hipótese inicial de traços de oralidade no léxico da obra, visto a gíria constituir um dos fenômenos mais representativos da língua falada.

Antes de procedermos ao levantamento e à análise de vocábulos gírios presentes em Quarto de despejo, é importante que façamos uma ressalva quanto ao uso de dicionários de gíria. Para Preti,

os dicionários de gíria não possuem um referencial básico, como os de língua, para decidir sobre o corpus de natureza oral. Utilizam-se de uma documentação escrita limitada e insuficiente, em geral constituída de textos de autores cujos narradores e personagens representam mais livremente a oralidade ou, ainda, de textos da imprensa popular. A experiência linguística do dicionarista, em geral, predomina na escolha e análise dos vocábulos que documentam a linguagem de grupos e que são incorporados ao dicionário. (PRETI, 2004, p. 78, grifos nossos)

Assim, reiteramos a dificuldade que um estudo desta natureza acarreta. Embora reconheçamos o vocábulo gírio quando lemos ou escutamos, seu enquadramento é uma questão social e não essencialmente linguística.

Quando o dicionarista consigna um vocábulo como gírio, o faz com base na própria experiência de falante, assim como os autores de dicionários comuns quando antepõem rubricas tais como coloq. (coloquialismo), bras. (brasileirismo) ou pop. (popular). Há dicionaristas que captaram muitas palavras e expressões de ouvido, cuja obra não segue o rigor do método científico.

Alguns dos vocábulos que seguem estão incorporados de tal modo à linguagem comum que talvez a própria noção de gíria acabe por se tornar questionável. Até que ponto a gíria deixa de ser gíria quando incorporada à língua comum? Pode-se falar, com propriedade, em "gíria comum"? 
Na entrada a seguir, de 18 de julho de 1955, logo nas primeiras páginas do relato encontramos quatro usos de vocábulos gírios, a saber, "vagabunda" (uma vez) e "maloca" (três vezes). Nesta passagem, o narrador registra um diálogo áspero com outra moradora da favela, que a insulta, chamando-a de "vagabunda".

18 de julho de 1955 (...) A Sílvia pediu-me para retirar o seu nome do meu livro. Ela disse:

- Você é mesmo uma vagabunda. Dormia no Albergue Noturno. O seu fim era acabar na maloca.

Eu disse:

- Está certo. Quem dorme no Albergue Noturno são os indigentes. Não tem recurso e o fim é mesmo nas malocas, e você, que diz nunca ter dormido no Albergue Noturno, o que veio fazer aqui na maloca? Você era para estar residindo numa casa própria. Por que a sua vida rodou igual a minha?

Ela disse:

- A única coisa que você sabe fazer é catar papel.

Eu disse:

- Cato papel. Estou provando como vivo! (p. 21, linhas 16-29)

11 de junho de 1958 (...) Um carro da Prefeitura que vinha trazer água jogava água e a Leila lavava. Ela dizia:

- Não fui eu quem tirou as roupas. Eu sou vagabunda, mas não sou ladra. (p. 59, linhas 16-20)

Neste caso, os vocábulos gírios não fazem parte da voz do narrador, mas estão na fala das personagens.

A gíria "vagabunda" é expressa no contexto também como forma de injúria, papel que a gíria desempenha em vários contextos e que não se limita aos estratos mais baixos da sociedade, mas aparece também na fala de pessoas de maior escolaridade ou de melhor condição social em situação de informalidade.

Embora seja um vocábulo antigo no português (século XIV, de origem latina segundo Houaiss), o uso de "vagabundo" é informal e pejorativo. Como gíria, seu significado é de "malandro", admitindo as formas variantes "vagal" e "vagau". (CABELLO, 1987, p. 126). Em Quarto 
de despejo, seu significado é o mesmo que se atribui atualmente, isto é, de indivíduo "ocioso", "desocupado" e "sem trabalho", muito próximo semanticamente do sentido de "malandro".

O vocábulo "maloca", de origem controversa, significa primariamente "aldeia indígena" ou grande habitação coletiva de povos indígenas, mas sofre um desvio de sentido e é empregado com o significado de "casa de condições precárias, desprovida de recursos de higiene" (BORBA, 2004, p. 873).

Ainda hoje, no século XXI, o derivado de "maloca", "maloqueiro", é empregado depreciativamente com o significado de "malandro", sentido diferente do original, ainda que pertencente do mesmo domínio semântico.

Sobre o vocábulo "vagabundo" (e cognatos), ao contrário do exemplo anterior, na entrada a seguir se dá na voz da narradora:

27 de agosto de 1958 (...) Cheguei em casa e pedi o carrinho da Rosalina emprestado e fui buscar madeira para fazer o chiqueiro. Levei a Vera e o José Carlos. Depois fiquei vagabundando. Depois que eu trabalho e ganho dinheiro para os meus filhos, vou descansar. É um descanso justo. (p. 115, linhas 15-19)

Neste caso, o vocábulo perde o seu tom agressivo e injurioso, não só pelo emprego autorreferencial como também pelo contexto de "descanso justo" após um período de trabalho estrênuo. Diferentemente da maior parte dos outros casos, o vocábulo gírio, aqui, faz parte da voz da narradora, não dos personagens. Este, todavia, não será o único momento em que o narrador emprega um vocábulo gírio.

Nas entradas a seguir aparecem os vocábulos "batucada", "batefundo" (duas vezes), "sururu" e "encrenca", todos com sentido aproximado de barulho e confusão:

15 de maio de 1958 (...) Tem noite que eles improvisam uma batucada e não deixa ninguém dormir. Os visinhos de alvenaria já tentaram com abaixo-assinado retirar os favelados. Mas não conseguiram (p. 32, linhas 33-36)

28 de maio de 1958 (...) Quando começa as brigas, os favelados deixam seus 
afazeres para presenciar os bate-fundos. De modo que quando a mulher sai correndo nua é um verdadeiro espetáculo para o Zé Povinho. (p. 46, linhas 12-16)

15 de agosto de 1958 (...) O povo estava esperando o Anselmo aparecer para the expancar. Reuniram homens e mulheres para o bate-fundo. (p. 109, linhas 20-22)

5 de junho de 1958 (...) O Euclides, o negro preto que mora com a Aparecida é horrível quando bebe. Fala por cem.

- Eu dou tiro. Eu mato!

Quando ele parou de falar era 3 horas da manhã. O visinho ligou o rádio. Eu não dormi com o sururu da favela. Até as crianças despertaram. (p. 162, linhas 03-08)

17 de julho de 1958 A Leila e o Arnaldo brigaram toda a noite. Não nos deixou dormir. Deixei o leito as 5 e meia e carreguei água. Na torneira sempre sai encrenca:

- Você passou na minha frente!

- Não passei!

E daí prossegue. (p. 93, linhas 01-06)

As cinco ocorrências possuem um traço semântico em comum: são todos semas de conteúdo interpretativo negativo dentro do contexto, associados à ideia de tumulto, distúrbio da ordem, atividade ruidosa e briga. Os moradores da favela, ruidosos, fazem "batucada", "bate-fundo", "sururu", e, briguentos, causam "encrenca".

Conforme mencionado anteriormente a gíria é, em princípio, um signo de grupo, isto é, um vocábulo marcado que caracteriza um grupo social específico.

Nos próximos exemplos, de 28 de junho e 09 de julho de 1958, aparecem dois vocábulos gírios oriundos do mundo do crime, "estar em cana" e "bater carteira". "Cana" significa cadeia, prisão; "bater carteira" significa "furtar carteira" e, por extensão, dinheiro ou qualquer pequeno pertence de um transeunte sem que este perceba.

Ambos os vocábulos, transformados em gíria comum, não aparecem despropositadamente em Quarto de despejo, pois são referentes a pessoas de má reputação.

No primeiro caso, o narrador descreve desfavoravelmente um suposto pai de santo chamado "Zuza", que entra "em cana", ou seja, é 
preso pela polícia. Segundo o narrador, "em cana" aparece na manchete de um jornal de 26 de junho de 1958, o que nos põe diante de um fenômeno curioso: a presença do vocábulo gírio em um jornal da época, o que revela um aproveitamento da oralidade na imprensa.

No segundo exemplo, o narrador descreve a ação de menores de idade envolvidos com a criminalidade e que furtam pequenos objetos, isto é, "batem carteira".

28 de junho de 1958 (...) Percebi que o senhor Zuza com a festa que fez para o povo em vez de atrair amigos atraiu inimigos. Eis o que estava escrito no jornal do dia 26 de junho de 1958:

"Zuza, pai de santo, em cana"

Zuza está em cana desde ontem, pois ele, que se chama na realidade José Onofre, e tem uma aparência realmente imponente, mantinha para lucros extraordinários uma tenda de Umbanda no Bom Retiro. A Tenda Pai Miguel Xangô. É também diretor de uma indústria de cadeiras suspeita de irregularidades na Delegacia de Costumes. "Zuza" (foto) foi autuado em flagrante. (p. 74, linha 30 - p. 75, linha 05)

06 de julho de 1958 ( $\ldots$ ) O João perdeu os 11 cruzeiros que eu dei-lhe para ir no Rialto. Ele levava o dinheiro na carteira e foi com os meninos da favela. E alguns deles já saber bater carteira. (p. 82 , linhas 11-14)

Trata-se de dois usos pejorativos advindos da malandragem, da criminalidade, e presentes em Quarto de despejo, provavelmente pelo seu largo emprego no ambiente.

Além desses, vejamos estes outros: "cacetes" (importunos, maçantes), "embrulhar" (enganar), "lenga-lenga" (conversa monótona) e "espelunca" (antro, lugar mal frequentado):

8 de junho de 1958 (...) Uma tarde de terça-feira. A sogra de Dona Ida estava sentada e disse:

- Podia dar uma enchente e arrasar a favela e matar esses pobres cacetes. Tem hora que eu revolto contra Deus por ter posto gente pobre no mundo, que só serve para amolar os outros.

A Tina da Dona Mulata, quando soube que a sogra da Dona Ida pedia a Deus para enviar uma enchente para matar os pobres favelados, disse:

- Quem há de morrer afogado há de ser ela! (p. 57, linhas 14-23) 
08 de junho de 1959 (...) O senhor Manoel chegou. Disse-lhe que a reportagem vai sair $4 .^{\text {a }}$ feira e que o repórter quer levar o livro para imprimir.

- Eles ganham dinheiro nas tuas costas e não te pagam. Eles estão te embrulhando. Você não deve entregar-lhe o livro.

Eu não imprecionei com as ironias do senhor Manoel. (p. 162, linhas 19-25)

03 de julho de 1959 (...) Tomei banho e fui deitar. Que noite horrível! A tal Terezinha e o companheiro não nos deixou dormir. Eu não sei onde eles arranjaram uma galinha. E discutiam:

- Vai, Euclides, depenar a galinha!

- Vai você!

E ficaram nessa lenga-lenga até as 2 da madrugada. (p. 169, 29-34)

08 de agosto de 1959 (...) A pior praga da favela atualmente são os ladrões. Roubam a noite e dormem durante o dia. Se eu fosse homem não deixava os meus filhos residir nesta espelunca. Se Deus auxiliar-me, hei de sair daqui, e não hei de olhar para trás. (p. 179, linhas 03-06)

Todas essas ocorrências de gíria parecem se enquadrar na constatação de Urbano:

parece-nos que o estado emocional do falante e, eventualmente, do ouvinte é dos mais determinantes, propiciando marcas linguísticas evidentes no enunciado dos interlocutores. (URBANO, 2000, p. 77)

Ainda que o autor não se refira ao fenômeno gírio, nem seja Quarto de despejo um texto falado, em todos esses casos há um componente emocional que não se pode ignorar.

Não apenas nesses três, mas em todos os vocábulos gírios parece haver um estado emocional latente marcado pela negatividade, o que ratifica a posição de uma narradora engajada emocionalmente.

As seguintes entradas, eliminadas por Audálio Dantas na editoração de Quarto de despejo, mas incluídas por Meihy na organização de Meu estranho diário, confirmam a sistematicidade observada nos exemplos anteriores.

Notamos os vocábulos "cupincha" (parceiro, cúmplice), "cacete" (maçante, tedioso) e "muamba" (mercadoria originária de roubo ou contrabando): 
2 de novembro de 1958 (...) Conversei com um senhor. Disse-Ihe que circula um buato que a favela vai acabar porque vão fazer Avenida Marginal. Ele disse que não é pra já. Que a prefeitura está sem dinheiro. Que o Dr. Adhemar não presta como político. Que outro prefeito trabalha. E o Dr. Adhemar não faz nada. Que ele seria um bom político. Mas que ele seria um bom político. Mas ele tem muito cupincha. Que se ele chegar a ser Presidente da República que o Brasil vira uma salada mista. Que qualquer sargento vai mandar. (p. 41, linhas 23-28)

16 de novembro de 1959 (...) Veio um homem queixar-se que o José Carlos havia jogado pedras no seu barracão e que ele ia levá-lo para o Juiz de menores. Que o meu filho é muito mal iducado. Que não tem medo de mim. Eu estava com sono e a voz cacete daquele homem me aborrecia. Eu disse-Ihe que já estou na favela a 12 anos e nunca fui na porta de ninguém fazer reclamações, que eu tolero crianças. ( $p .71$, linha 32 - p. 72, linha 03)

19 de novembro de 1958 (...) Fui no depósito, puis a muamba dentro do samburá e vim para casa. Cheguei antes dos filhos, preparei o almoço. (p. 81, linhas 0607)

Conquanto os três vocábulos tenham perdido com o passar dos anos seu aspecto de gíria de grupo, pelo menos dois, cupincha e muamba, continuam sendo empregados na linguagem corrente com o mesmo sentido depreciativo. Cupincha é usado com referência a pessoas que são parceiras ou protegidas de indivíduos poderosos; muamba, embora não tenha exatamente o sentido que Carolina emprestou à palavra, possui o sentido de objeto contrabandeado. Pelo contexto, parece que o narrador se referia a um objeto qualquer.

Por causa da própria condição marginal e flutuante na língua, a gíria permanece com uso restrito na modalidade oral. Quando empregada na escrita, como em Quarto de despejo, mantém sua natureza de marca oral, de traço da variação diastrática, de uso "não culto".

A respeito do uso da gíria, Urbano diz que "tal é a sua força expressiva que dificilmente uma conversação espontânea, descontraída, numa linguagem distensa do dia a dia pode dela prescindir". (URBANO, 2011, p. 93)

De fato, mesmo que a narradora de Quarto de despejo preferisse 
prescindir desse uso, a força expressiva da gíria a torna um vocabulário onipresente na língua falada e no texto escrito com traços de oralidade.

Daí a afirmação inicial de que a gíria, quando se incorpora à linguagem comum, deixa de ser gíria de grupo e passa a ser gíria comum. Tal aspecto pode ser resumido pela constatação de Preti: "Alguns estudiosos entendem que a verdadeira gíria possui uma condição criptológica inerente e, quando divulgada pelos dicionários... deixa de ser gíria". (PRETI, 2004, p. 80)

Dos exemplos em revista, o lexema vagabundo é o mais abundante em Quarto de despejo, presente inclusive em expressões injuriosas, e poderia, também, ser enquadrado como um vocábulo de uso informal, assim como muitos outros. Muitos vocábulos gírios acabam por se incorporar definitivamente à linguagem de uso informal e perdem, na intuição dos falantes, o caráter de signo de grupo.

Vocábulos tais como maloca, batucada, encrenca, bagunceiro, espelunca ou lengalenga estão de tal maneira incorporados ao uso corrente, que no tempo da escrita de Carolina (década de 50 do século $\mathrm{XX}$ ) já haviam perdido seu aspecto criptológico e foram empregados pela narradora em seu relato sem receio de não ser compreendida pelos seus leitores.

\subsection{3 - A imprecisão de sentido: vocábulos semanticamente desfocados}

Preti e Urbano, já citados (cf. cap. 4.5.3), mencionam a imprecisão e deturpação de sentido que tendem a ocorrer no vocabulário da língua falada. Em Quarto de despejo há um número expressivo de ocorrências de lexias de sentido impreciso, genérico ou deslocado.

20 de julho de 1955 (...) Preparei a refeição matinal. Cada filho prefere uma coisa. A Vera, mingau de farinha de trigo torrada. O João José, café puro. O José Carlos, leite branco. E eu, mingau de aveia. (p. 23, linhas 06-09) 
30 de maio de 1958 ...Troquei a Vera e saímos. Ia pensando: será que Deus vai ter pena de mim? Será que eu arranjo dinheiro hoje? Será que Deus sabe que existe as favelas e que os favelados passam fome?

.... José Carlos chegou com uma sacola de biscoitos que catou do lixo. Quando eu vejo eles comendo as coisas do lixo penso: E se tiver veneno? É que as crianças não suporta a fome. Os biscoitos estavam gostosos. Eu comi pensando naquele provérbio: quem entra na dança deve dançar. E como eu tenho fome, devo comer. (p. 47, linhas 23-32)

12 de novembro de 1958 (...) Quando eu fui pegar água contei para a D. Angelina que eu havia sonhado que tinha comprado um terreno muito bonito. Mas eu não queria ir residir lá porque era litoral e eu tinha medo dos filhos cair no mar.

Ela disse-me que só mesmo no sonho é que podemos comprar terrenos. No sonho eu via as palmeiras inclinando-se para o mar. Que bonito! A coisa mais linda do mundo é o sonho.

Achei graça nas palavras da D. Angelina, que disse-me a verdade. O povo brasileiro só é feliz quando está dormindo. (p. 131, linha 28 - p. 132, linha 03)

3 de fevereiro de 1959 Tenho de dizer que eu não escrevi nos dias que decorreram porque eu fiquei doente. Vou recapitular o que ocorreu comigo nestes dias. (...) A Fernanda veio e perguntou-me se eu sei onde está o cigano. É a mesma coisa que ela perguntar-me onde é a casa do vento. (p. 152, linhas 07-11)

A palavra-ônibus possui a função de substituir outras e, sob seu leque, os sentidos específicos diluem-se. A palavra "coisa" conta com um amplo espectro de significações e nuanças de sentido, sendo empregada em lugar de substantivos comuns que designam objetos, por exemplo, e sob sua égide pode-se encontrar uma multiplicidade infinita de itens.

Nos exemplos de 20 de julho de 1955 e 30 de maio de 1958, a palavra coisa refere-se a itens alimentícios. Como a narradora não específica a que se refere (feijão, arroz, carne, batata etc.), o leitor pode supor qualquer um que não estará equivocado. O que, por ora, percebemos é que o emprego da palavra coisa está tão arraigado na língua oral e, consequentemente, na escrita, que é tarefa dificílima substituí-la por outra. 
Além das ocorrências da palavra-ônibus "coisa", destaca-se no texto o largo emprego da palavra "nortista" (com o sentido impreciso de nordestino), típico da língua falada popular:

28 de maio de 1958 (...) O que eu quero esclarecer sobre as pessoas que residem na favela é o seguinte: quem tira proveito aqui são os nortistas. Que trabalham e não dissipam. Compram casa ou retornam-se ao Norte. (p. 46, linhas 32-35)

13 de agosto de 1958 ... Vieram queixar-se que a Zefa brigou com uma nortista e discutiram. Os calões entraram em ação. Eu só tenho dó das crianças que ouvem os impropérios. (p. 106, linhas 27-29)

24 de dezembro de 1958 (...) No centro Espírita a fila já estava enorme quando nós chegamos. (...) Os 10 filhos de uma nortista estavam pedindo pão. A Dona Maria Preta deu 15 cruzeiros para ela. Ela foi comprar pão. (p. 139, linhas 28-31)

Tanto a palavra "norte" (= "nordeste") quando "nortista" (= nordestino) aparecem em Quarto de despejo e constituem, a nosso ver, traços de língua falada, visto serem itens lexicais empregados de modo impreciso, com deturpação de sentido.

Embora sejam frequentes na língua falada os lexemas "norte" em vez de "nordeste" e "nortista" em vez de "nordestino", tais acepções ainda não são registradas por Houaiss (2001) ou Borba (2004), por exemplo. Entendemos essa ausência de registro em dicionários de língua como evidência adicional do traço oral do uso desses vocábulos.

\subsection{4 - A presença da linguagem de uso vulgar em Quarto de despejo}

A intenção de Carolina é relatar ipsis litteris todos os acontecimentos da favela. Até os mais escabrosos são relatados em todos os seus pormenores. Nesses momentos, tudo o que se refere à sexualidade, inclusive a praticas pervertidas, é contado pormenorizadamente. Assim como um solilóquio, tudo é relatado sem censura, de modo bastante natural e espontâneo. 
Ressalte-se que não existe uma linguagem essencialmente vulgar, mas uma linguagem de uso vulgar. Ainda que muitos vocábulos constituam tabus linguísticos, essa condição é um reflexo de fatores extralinguísticos, consagrados pela cultura da sociedade. Ainda que alguns vocábulos sejam prontamente reconhecidos como grosseiros, outros somente o serão dentro de contextos específicos.

Em nítido contraste com a busca das palavras raras e belas, a narrativa de Carolina exibe várias ocorrências de vocábulos de uso vulgar, mormente obsceno, na maioria de sema sexual, embora também ocorram alguns escatológicos.

Seguem os exemplos, com seus devidos contextos:

4 de julho de 1958 (...) Quando os meus filhos eram menores eu deixava eles fechado e saía para catar papel. Um dia eu cheguei e encontrei o João chorando. Ele disse-me:

- Sabe, mamãe, a Dona Rosa me jogou bosta no rosto.

Eu acendi o fogo, esquentei a água e lavei as crianças. Fiquei horrorizada com a maldade da Dona Rosa. (p. 80, linha 33 - p. 81, linha 03)

8 de agosto de 1958 (...) A Quita veio no meu barracão reclamar que o José Carlos havia jogado bosta no rosto da Marli, e que eu devo dar mais educação ao meu filho. (p. 105, linhas 22-24)

26 de setembro de 1958 (...) Chegamos na Rua Asdrúbal do Nascimento. (...) Eu fui falar com uma senhora que queria saber o que ocorria com o João.

Ela perguntou ao João se ele sabia o que era fazer porcaria. Ele disse que sabia. E se ele havia feito porcaria na menina. Ele disse que não. (p. 120, linhas 04-10)

22 de outubro de 1958 (...) Dei o jantar aos filhos, eles foram deitar-se e eu fui escrever. Não podia escrever socegada com as cenas amorosas que se desenrolavam perto do meu barracão.

Pensei que iam quebrar a parede!

Fiquei horrorisada porque a mulher que estava com o Lalau é casada. Pensei: que mulher suja e ordinária! Homem por homem, mil vezes o esposo!

Creio que um homem só chega para uma mulher. Uma mulher que casou-se precisa ser normal. 
Esta história das mulheres trocar-se de homens como se estivesse trocando de roupa, é muito feio. Agora uma mulher livre que não tem compromissos pode imitar o baralho, passar de mão em mão. (p. 122, linhas 13-25)

3 de novembro de 1958 (...) Parei na linha do trem para pegar umas latas porque eu havia deixado perto da gurita e pedi ao guarda para guardar. (...) Disse que a vida está muito cara. Que até as mulheres estão caras. Que quando ele quer dar uma f... as mulheres quer tanto dinheiro que ele acaba desistindo.

Fingi que não ouvi, porque eu não falo pornografia. Saí sem agradecê-lo. (p. 127, linhas 01-03, 08-12)

21 de novembro de 1958 (...) Hoje de manhã eu disse para o Seu Joaquim Purtuguês que a filha da D. Mariquinha não sabia ler. Ele disse:

- F... elas aprendem. E aprendem sem professor.

Eu dei uma risada e disse:

- Purtuguês não presta! (p. 134, linhas 03-07)

09 de junho de 1959 (...) O João disse-me que o Orlando Lopes, o atual encarregado da luz, havia me chingado. Disse que eu fiquei devendo 4 meses. Fui falar com o Orlando. Ele disse-me que eu puis na revista que ele não trabalha.

- Que história é essa que eu fiquei devendo 4 meses de luz e água?

- Ficou, sim, sua nojenta! Sua vagabunda!

- Eu escrevo porque preciso mostrar aos políticos as péssimas qualidades de vocês. E vou contar ao repórter.

- Eu não tenho medo daquele puto, daquele fresco!

Que nojo eu senti do tal Orlando Lopes. (p. 164, linhas 18-28)

18 de junho de 1959 (...) A Aparecida veio dizer que o João mandou ela tomar no...

Eu disse:

- Vocês são as professoras. Quando bebem falam coisas horríveis. (p. 166, linha 34 - p. 167, linha 03)

27 de junho de 1959 ...O tal Orlando Lopes passava de bicicleta. Os meus filhos falaram:

- Olha o Orlando!

Eu disse-Ihes:

- Eu não vou olhar para este nojento.

Ele ouviu e respondeu:

- Nojento é a puta que te pariu! 
Eu disse-lhe que ia escrever e não podia perder tempo com vagabundos. Fechei a porta. (p. 168, linhas 01-09)

28 de julho de 1959 (...) A luz da favela estava acesa. E a porta do barracão da Leila estava fechada. Vi várias crianças olhando pela fresta. Queria ir ver. Mas há certas coisas que desabonam o adulto. Quando o José Carlos entrou, disse:

- Eu tenho uma coisa para contar.

- O que é?

- Eu vi o Chico fazendo bobagem com a P.

Não dei margem para o assunto. Ele prosseguia:

- O Chico fazia bobagem com a P. e a Vanilda estava perto olhando.

A Vanilda tem 2 anos! (p. 176, linhas 14-24)

6 de julho de 1959 O senhor Manoel saiu. E eu fiquei deitada. Depois levantei e fui carregar água. Que nojo. Ficar ouvindo as mulheres falar. Falaram da D., que ela namora qualquer um. Que a R., irmã do B., pertence aos homens.

Falamos do J. P., que quer amasiar-se com a sua filha I. (...) Ele mostra para a filha e convida...

-Vem, minha filha! Dá para o seu papaizinho! Dá... só um pouquinho.

Eu já estou cansada de ouvir isto, porque infelizmente eu sou visinha do J.P. (...) É um homem que não pode ser admitido numa casa onde tem crianças.

Eu disse:

É por isso que eu digo que a favela é o chiqueiro de São Paulo.

Enchi minha lata e zarpei, dando graças a Deus por sair da torneira. A C. disse que pediu dinheiro ao seu pai para comprar um par de sapatos, e ele disse:

Se você me der a.... eu te dou 100. Ela deu. E ele deu-lhe só 50. Ela rasgou o dinheiro e a I. catou os pedaços e colou.

Porisso que eu digo que a favela é o Gabinete do Diabo. (p. 170, linhas 01-25)

31 de julho de 1959 ...Comprei 20 de carne gorda, porque eu não tenho gordura. Passei no empório do senhor Eduardo para comprar 1 quilo de arroz. Deixei os sacos na calçada. A Vera pois a carne em cima do saco, o cachorro pegou. Chinguei a Vera:

- Ordinária, preguiçosa. Hoje você vai comer m...

Ela dizia:

- Deixa, mamãe. Quando eu encontrar o cachorro eu bato nele. (p. 177, linhas 01-07)

Os exemplos a seguir foram eliminados por Audálio Dantas na edição de Quarto de despejo e constam em Meu Estranho Diário. Evidentemente, tendo em vista o processo de editoração e o público-leitor 
em potencial para a obra, o editor procurou suprimir ou atenuar os vocábulos mais "fortes".

12 de novembro de 1958 (...) A Deolinda contou para as mulheres da favela que o Lalau cagou na cama. O Lalau é seu esposo. Que ele bebeu demais. Penso que uma boa esposa não divulga o que se passa com o esposo. Mas a Deolinda não recebeu educação. Sua mestra foi a garrafa de pinga. (p. 65, linhas 20-24)

17 de novembro de 1958 (...) Voltamos a Pitita.

Quando a Pitita briga todos saem para ver. É um espetáculo pornográfico. Ela disse, dirigindo ao esposo:

- Ele é um chupador!

E o Duca perguntou-lhe:

- E que é que ele chupa?

Ela mostrou e disse:

- Ele... chupa a minha buceta. - Os homens sorriram. E as crianças ficaram repitindo. E sorrindo, e dizendo que haviam visto a buceta da Pitita, e que estava cheia de cabelos.

E as crianças ficam comentando: - por que será que a buceta das mulheres tem cabelos?

As meninas comentam:

- A minha ainda não tem!

As crianças começaram a falar que Pitita havia erguido o vistido. Eu vim para dentro de casa. Eu já estava deitada e ouvia a voz cavernosa da Pitita.

A tarde na favela foi de amargar. E assim as crianças da favela ficaram sabendo que os homens chupam as mulheres.

Estas coisa eles não mais duvida. Tenho dó destas crianças que vivem num quarto de despejo mais imundo que há no mundo e tem uns professores incultos, pessoas que, praticando estes atos imundos, concorrem para a má formação das crianças. (p. 77, linha 33 - p. 78, linha 20)

19 de novembro de 1958 (...) Estendi as roupas e preparei o jantar para os filhos. Quando eu estava acendendo o fogão, o José Carlos surgiu correndo: era um valentão que corria atrás dele - um nortista. Eles me chingam. Eu chingo também. Se mostrar fraqueza para os nortistas... eles prevalecem. Penso: será que os governos do Norte são governos marca merda, que não se interessa pela cultura dos nortistas?

O nortista quando tem cultura é passável. Quando é inculto, é intolerável. (p. 82, linhas 17-25) 
A maioria das ocorrências é de lexias de cunho sexual. A edição de Quarto de despejo tratou de expurgar as passagens mais cruas dos registros de Carolina, substituindo, em algumas passagens, os vocábulos chulos por reticências. O exemplo dar uma $f \ldots$, no texto original não apresenta as reticências e aparece dar uma foda.

O exemplo de 17 de novembro de 1958, quando relata a atitude das crianças frente às práticas sexuais dos adultos nos parece bastante emblemático da crueza do relato de Carolina. A narradora registra um diálogo de conteúdo explicitamente obsceno, reproduzindo ipsis litteris um vocabulário chulo e agressivo para descrever o sexo oral.

Em contrapartida, o ato sexual mais agressivo é descrito, em outra passagem, pela expressão fazer bobagem, de natureza eufêmica, idêntica a fazer porcaria.

Na entrada de 6 de julho de 1959, não ocorre apenas um vocábulo obsceno. ("Dar", de conteúdo sexual). Talvez a um leitor comum falte a percepção de que a narradora esteja se referindo ao que hoje chamamos de pedofilia. Não é possível determinar com exatidão o que é omitido pelas reticências. Inferimos como objeto direto de dar os substantivos, também de uso obsceno, bunda ou buceta, visto que ocorrem na linguagem vulgar as expressões dar a bunda e dar a buceta. Entretanto, como o trecho em questão não aparece em Meu estranho diário, não é possível determinar com exatidão qual item lexical foi omitido. Apesar da omissão, acreditamos que é um detalhe irrelevante: independentemente de qual item tenha sido omitido, o aspecto obsceno é o mesmo.

Na entrada de 31 de julho de 1959, em contrapartida, quando relata seu desentendimento com a filha Vera Eunice, é possível recuperar a expressão na íntegra (comer merda) porque a edição mantém o primeiro grafema da palavra.

O que chama a atenção no emprego do léxico vulgar em Quarto de despejo é que a maior parte das ocorrências se dá não na voz da 
narradora, mas nas falas dos personagens, reproduzidas por meio de discurso direto, daí a liberdade de registrar esses vocábulos sem emprego de eufemismos.

Ressaltamos também que, ainda que eventualmente presentes na narração, os vocábulos vulgares ou grosseiros não são constitutivos da voz da narradora. Mesmo que ela não hesite em empregá-los quando, segundo seu relato, são enunciados por personagens da vida quotidiana da favela, esta é a natureza das ocorrências: não é "ela" quem os enuncia, apenas "passa a palavra" a outrem. São as pessoas "incultas" e "pornográficas" da favela que "falam pornografia", não ela.

Nos momentos em que os itens lexicais vulgares são da narradora, não se trata de vocábulos muito agressivos como os que ela relata na voz de outrem. Quando diz "comer merda", a expressão vulgar possui um caráter interjetivo, expressando um momento de contrariedade ante uma atitude inconveniente da filha. A expressão vulgar funciona como um desabafo da narradora diante dos seus infortúnios. Nos dois casos, o mesmo lexema (merda), embora grosseiro, não possui traço semântico de sexualidade ou de perversão sexual, como em outros.

Carolina assume o papel de porta-voz dos acontecimentos: seu papel é narrar o que acontece à sua volta, mesmo que não goste daquilo que ouve. Isso pode ser claramente deduzido pelo contexto de algumas dessas ocorrências e do que Carolina afirma em sequência.

$\mathrm{Na}$ entrada em que aparece a expressão "dar uma foda" (3 de novembro de 1958), trata-se do diálogo entre Carolina e um guarda que Ihe dera algumas latas. Depois de registrar a frase grosseira do guarda, Carolina afirma: "Fingi que não ouvi, porque eu não falo pornografia. Saí sem agradecê-lo".

Haveríamos de nos questionar por que um homem diria uma frase dessa crueza para uma mulher. Seria uma proposta sexual camuflada? Ou 
seria um comentário em vista da condição social de Carolina, que não inspirava respeito? Ou as duas possibilidades não se excluem?

Reconhecemos que estamos fazendo apenas uma ilação, mas o contexto permite olhar além do mero registro dos lexemas e captar a intenção de Carolina de apenas registrar o seu quotidiano, mesmo quando o assunto Ihe é particularmente desagradável.

$\mathrm{Na}$ entrada de 21 de novembro de 1958 (logo, apenas poucos dias depois do encontro com o guarda), em que um português Ihe diz "foder... elas aprendem e aprendem sem professor", encontramos a narradora em situação de familiaridade com seu interlocutor, o que lhe permite rir do comentário obsceno deste: "Eu dei uma risada e disse: - Purtuguês não presta!" Embora "não fale pornografia", Carolina ri diante do mesmo vocábulo mencionado anteriormente. Provavelmente 0 fato de ter relativamente intimidade com o outro interlocutor resulte em uma reação diferente da esboçada anteriormente.

Na entrada de 18 de junho de 1959, quando usa a expressão "tomar no...", o narrador dá novamente a voz a outrem. Como o trecho em questão não aparece em Meu estranho diário, não temos como saber se as reticências são da autora ou de Audálio Dantas. Inferimos que a personagem não tenha omitido a palavra "cu", integrante dessa expressão grosseira e injuriosa, "tomar no cu", e que Carolina deve ter registrado ipsis litteris, em vista da sua obsessão em narrar pormenorizadamente cada acontecimento na favela.

Destaque-se também que as expressões "fazer bobagem" e "passar de mão em mão", embora vulgares, não possuem a agressividade e a crueza de outras que aparecem no relato.

Embora sejam todos vocábulos de uso vulgar, é nítido que há uma gradação entre eles, e não são todos que possuem a mesma tonalidade agressiva e disfêmica. Alguns, mais frequentes na linguagem espontânea, aparecem com maior naturalidade. 
5.1.5 - A linguagem injuriosa dos moradores da favela

Há um número significativo de palavras e expressões injuriosas. São, na grande maioria, constituídas de expressões que foram dirigidas à pessoa de Carolina por outros moradores da favela.

Não se trata de casos em que a ofensa surge meramente do calor do momento. São todos casos em que a injúria possui conotação preconceituosa e racista.

As pessoas insultam Carolina fazendo alusão ao fato de ser negra e à condição de catadora de papel. O racismo aparece com muita frequência em Quarto de despejo e, nesse sentido, os itens lexicais injuriosos dirigidos contra Carolina possuem motivação racista.

Percebemos essa onipresença do racismo nas entradas de 24 de julho de 1955 ("negra fidida"), 21 de julho de 1958 ("negra suja") e 16 de fevereiro de 1959 ("negra ordinária"), momentos em que as pessoas chamam Carolina de "negra" de forma pejorativa, acompanhado dos adjetivos de carga semântica negativa, "fidida", "suja" e "ordinária".

18 de julho de 1955 (...) A Sílvia pediu-me para retirar o seu nome do meu livro. Ela disse:

- Você é mesmo uma vagabunda. Dormia no Albergue Noturno. O seu fim era acabar na maloca.

Eu disse:

- Está certo. Quem dorme no Albergue Noturno são os indigentes. Não tem recurso e o fim é mesmo nas malocas, e você, que diz nunca ter dormido no Albergue Noturno, o que veio fazer aqui na maloca? Você era para estar residindo numa casa própria. Por que a sua vida rodou igual a minha?

Ela disse:

- A única coisa que você sabe fazer é catar papel.

Eu disse:

- Cato papel. Estou provando como vivo! (p. 21, linhas 16-29)

24 de julho de 1955 (...) Quando cheguei em casa encontrei a D. Francisca brigando com meu filho João José. Uma mulher de quarenta anos discutindo com uma 
criança de seis anos. Puis o menino para dentro e fechei o portão. Ela continuou falando. Para fazer ela calar é preciso lhe dizer:

\section{- Cala a boca tuberculosa!}

Não gosto de aludir os males físicos porque ninguém tem culpa de adquirir moléstias contagiosas. Mas quando a gente percebe que não pode tolerar a impricância do analfabeto, apela para as enfermidades. (p. 27, linha 28 - p. 28, linha 02)

24 de julho de 1955 (...) Sentei ao sol para escrever. A filha da Sílvia, uma menina de seis anos, passava e dizia:

- Está escrevendo, negra fidida!

A mãe ouvia e não repreendia. São as mães que instigam. (p. 28, linhas 07-11)

21 de julho de 1958 (...) Enquanto eu estava na rua o Alexandre maltratou a mãe do soldado Edison. Quando eu cheguei ele começou a insultar-me:

- Negra suja! Ordinária. Vagabunda. Lixeira.

Eu não tenho paciência, Ihe chinguei, joguei-Ihe um vidro no rosto. Ele fechou a janela. (p. 97, linha 06-11)

16 de fevereiro de 1959 (...) Quando cheguei na favela o povo me olhava. A Dona Sebastiana chingava. Estava embriagada. Dizia que ela degolava o baiano. Eu dizia para ela não chegar, que ela ia morrer. Ela começou a chingar-me:

- Negra ordinária! Você não é advogada, não é repórter e se mete em tudo! (p. 153, linhas 24-29)

09 de junho de 1959 (...) O João disse-me que o Orlando Lopes, o atual encarregado da luz, havia me chingado. Disse que eu fiquei devendo 4 meses. Fui falar com o Orlando. Ele disse-me que eu puis na revista que ele não trabalha.

- Que história é essa que eu fiquei devendo 4 meses de luz e água?

- Ficou, sim, sua nojenta! Sua vagabunda!

- Eu escrevo porque preciso mostrar aos políticos as péssimas qualidades de vocês. E vou contar ao repórter.

- Eu não tenho medo daquele puto, daquele fresco!

Que nojo eu senti do tal Orlando Lopes. (p. 164, linhas 18-28)

18 de junho de 1959 (...) O barraco da Aparecida é o ponto para reunir os pinguços. Beberam e depois brigaram. O Lalau disse que eu ponho várias pessoas no jornal, mas ele eu não ponho.

- Se você me pôr no jornal eu te quebro toda, vagabunda! Esta negra precisa sair daqui da favela. (p. 166, linhas 33-38)

Por que Carolina é tão vilipendiada pelos outros moradores da favela? 
Os vizinhos de Carolina sabem que ela escreve o relato da favela. Essa escrita revela-se problemática em dois aspectos a nosso ver fundamentais para compreendermos o contexto dos acontecimentos.

Primeiro, numa época em que grande parcela da população era analfabeta (lembremos que o diário foi escrito na década de 50), Carolina tinha um privilégio que a maioria dos "favelados" não tinha: sabia ler e escrever. Isso, naturalmente, despertava inveja dos outros.

Segundo, o relato de Carolina era altamente comprometedor. $\mathrm{Na}$ sua ânsia de escrever tudo o que acontecia, ela relatava os acontecimentos com pormenores constrangedores e comprometedores para os outros: Carolina relata casos de roubo, estupro e pedofilia. Como se fosse uma "advogada" ou "repórter", ela se envolve nas brigas que ocorrem na favela. Naturalmente sua posição não era apreciada pelos outros, que não queriam um "repórter" a apontar seus erros. Esse aspecto nos parece mais relevante para compreender a atitude dos falantes conforme o relato de Carolina.

$\mathrm{Na}$ entrevista que nos concedeu, Vera Eunice relatou que, quando Carolina enfim se mudou da favela do Canindé em 1960, o caminhão de mudanças foi apedrejado, e uma pedra acertou a testa de seu filho José Carlos, que até hoje tem a cicatriz.

\subsection{6 - O uso de hipocorísticos e apelidos}

Também ocorrem em diversas passagens lexemas de traço afetivo, típicos da linguagem familiar e/ou informal.

Os hipocorísticos e os apelidos com que a narradora se refere a pessoas da favela também constituem um traço de língua falada.

Assim como os itens anteriormente analisados, os hipocorísticos e os apelidos também possuem uso limitado, não sendo empregados na língua escrita formal. Dessa forma, formas como "Zefa", "Zuza" ou "Chico" são 
de emprego limitadíssimo na língua escrita, não fazendo parte do repertório vocabular típico da língua escrita. Esse modo informal de se denominarem as pessoas possui um destacado aspecto oral, e sua presença na escrita constitui, portanto, um traço de língua falada.

18 de julho de 1955 (...) Tem a Maria José, mais conhecida por Zefa, que reside no barracão da Rua B número 9. É uma alcoólatra. Quando está gestante bebe demais. E as crianças nascem e morrem antes dos doze meses. (p. 18, linhas 08-11)

13 de maio de 1958 (...) Eu tenho tanto dó dos meus filhos. Quando eles vê as coisas de comer eles brada:

- Viva a mamãe! (p. 32, linhas 14-16)

2 de junho de 1958 Amanheceu fazendo frio. Acendi o fogo e mandei o João ir comprar pão e café. O pão, o Chico do Mercadinho cortou um pedaço.

Eu chinguei o Chico de ordinário, cachorro, eu queria ser um raio para cortar-lhe em mil pedaços. O pão não deu e os meninos não levaram lanche. (p. 50, linhas 18-23)

8 de junho de 1958 (...) Uma tarde de terça-feira. A sogra de Dona Ida estava sentada e disse:

- Podia dar uma enchente e arrasar a favela e matar esses pobres cacetes. Tem hora que eu revolto contra Deus por ter posto gente pobre no mundo, que só serve para amolar os outros.

A Tina da Dona Mulata, quando soube que a sogra da Dona Ida pedia a Deus para enviar uma enchente para matar os pobres favelados, disse:

- Quem há de morrer afogado há de ser ela! (p. 57, linhas 14-23)

22 de junho de 1958 (...) Apareceu um preto alto e gordo como se fosse decendente de elefante. Falava para todos ouvir.

- Eu não sou deputado. Sou simplesmente amigo do povo humilde.

Comecei a escrever o que observava daquela agromeração. O senhor Zuza viume escrevendo. Porque eu sou alta e estava toda de vermelho. Fui falar-lhe. PergunteiIhe:

- Quem é o senhor?

- Ô gente! Eu sou o Zuza! A senhora nunca ouviu falar no Zuza? Pois o Zuza sou eu!

- Com que finalidade o senhor faz esta festa?

- Faço esta festa para o povo.

- Eu vou pôr o senhor no jornal.

- Você pode me pôr onde você quizer... 
Não simpatizei com o tal Zuza. Falta qualquer coisa naquele homem, para ele ser um homem completo. (p. 68, linha 30 - p. 69, linha 09)

29 de junho de 1958 (...) Fiquei esperando a Purtuguesa de Desportos soltar os foguetes, porque se eu deitasse antes tinha que despertar com os foguetes. Uma senhora que esquentava fogo disse-me que a Angelina Preta bateu no seu filho Argemiro de oito anos e não quer que ele passe na Rua A para pegar água. (p. 77, linhas 15-19)

1 de julho de 1958 (...) A minha simpatia pela dona Chiquinha arrefeceu. No outro dia a dona Chiquinha veio perguntar se eu queria brigar com ela que ela ia buscar a peixeira. Não Ihe dei confiança. (p. 79, linhas 06-09)

8 de julho de 1958 (...) Esquentei a comida e dei-lhes. O barulho noturno que ouvi: as mulheres estavam comentando que os homens beberam 14 litros de pinga. E a Leila insultou um jovem e ele espancou-a. Lhe jogou no solo e deu um pontapé no rosto. $O$ ato é selvagem. Mas a Leila quando bebe irrita as pessoas. Ela já apanhou até do Chiclé, um preto bom que reside aqui na favela. Ele não queria espancá-la. Mas ela desclassificou-lhe demais. Ele deu-lhe tanto que até arrancou-lhe dois dentes. E por isso o apelido dele aqui na favela é Dentista. A Leila ficou com o rosto tão inchado que foi preciso tomar pinicilina. (p. 85, linhas 14-24)

19 de julho de 1958 (...) Dois nortistas brigaram. Só procuraram insultos. O Vítor Franquistém, o valentão, apanhou do Valdemar Espadela. Todos gostaram porque o Vítor quer ser o Lampeão da favela. Foram 2 cacetadas. Agora as mulheres estão dizendo que vão cotisar e comprar uma camisa de lã para dar de presente ao Valdemar para comemorar o seu grande feito. (p. 94, linhas 22-27)

Os apelidos, assim como os hipocorísticos, também são de largo emprego na língua falada. São atribuídos a pessoas de acordo com o contexto social, e não é possível, em grande parte dos exemplos, deduzirIhes os significados.

Assim, apelidos como "Valdemar Espadela", "Pitita", "Binidito Onça" são de significação incompreensível para nós.

"Vítor Franquistém" parece ser uma alusão a Frankenstein, personagem interpretado pelo ator britânico Boris Karloff (1887-1969) em filmes de terror de bastante sucesso nas décadas de 1930, 1940 e 1950. Os filmes são inspirados na obra da romancista inglesa Mary Shelley 
(1797-1851). Sua novela gótica Frankenstein ou o moderno Prometeu relata a história de um jovem cientista, Victor Frankenstein, que cria um monstro em um laboratório.

A história, bastante popular desde sua publicação (1818), inspirou vários filmes de terror protagonizados por Boris Karloff, que se tornou um ícone do personagem. Frankenstein, que é não o nome da criatura mas do criador, passou a designar o nome do monstro e, por extensão, qualquer indivíduo muito alto e feio. Talvez seja essa a origem do apelido "Vítor Franquistem", com o nome aportuguesado pela narradora.

Outro exemplo curioso é um indivíduo cujo apelido é "dentista". Neste caso, a narradora esclarece o porquê do apelido. "Valdemar Espadela", por distorção do significante, parece aludir a "espáduas", isto é, parece indicar que seja um homem alto e de ombros largos, mas não podemos fazer uma afirmação categórica.

Independentemente, no entanto, dos significados dos apelidos e dos hipocorísticos, trata-se de um vocabulário de emprego farto na língua falada e limitado na língua escrita.

5.2 - A Expressividade de um léxico em permanente colisão

5.2.1 - Os campos semânticos de Quarto de despejo

Conforme vimos anteriormente, cada lexia desempenha uma função na organização textual, e um determinado conjunto de vocábulos com os mesmos traços semânticos estabelece relações de sentido no texto, configurando um campo semântico.

Em Quarto de despejo quase tudo é negativo, sombrio, triste. E essa atmosfera lúgubre é caracterizada pelas escolhas operadas pela autora. Alguns campos semânticos são marcantes ao longo do texto.

A precariedade do espaço físico e a condição de penúria em que 
Carolina vive com os filhos despertam uma gama de sentimentos negativos e uma visão de mundo extremamente pessimista. Esses sentimentos negativos são traduzidos ou representados por uma série de unidades lexicais características.

Assim, as unidades lexicais de Quarto de despejo configuram uma rede de significações que veremos brevemente nos próximos itens, "a pobreza" e "a favela".

\subsubsection{1 - A pobreza}

Pobreza é um vocábulo definido como "falta ou escassez de recursos; penúria" (BORBA, 2004, p. 1084). Esta é a situação de Carolina e seus pares na favela do Canindé: a absoluta escassez, a penúria.

Talvez a palavra "miséria" seja mais exata, definida pelo mesmo autor como "pobreza extrema" (id, p. 925). Essa condição de extrema pobreza é tematizada ao longo do texto de Quarto de despejo por um leque variado de lexias (tanto simples quanto compostas) de traço negativo.

Tais vocábulos e expressões caracterizam as pessoas pobres, a ambiência da favela e a fome, um fantasma onipresente da primeira à última página do relato de Carolina. Evocamos aqui a constatação de Câmara Jr. de que "o vocábulo sofre o contágio das sensações agradáveis ou desagradáveis que decorrem das próprias coisas" (CÂMARA JR., 1953, p. 73).

Por essa razão apontamos as unidades "maloca", "barracão" e "catar" como pertencentes ao universo temático da pobreza, interligados com a favela, e constituintes de uma situação de desespero e abandono.

Apesar de o diagrama conter apenas oito exemplos colhidos da obra, poderíamos, abstratamente, pensar em um grande diagrama com todos os vocábulos da obra, que ascendem a centenas, pois a pobreza e a 
miséria são tematizadas da primeira à última linha da narrativa.

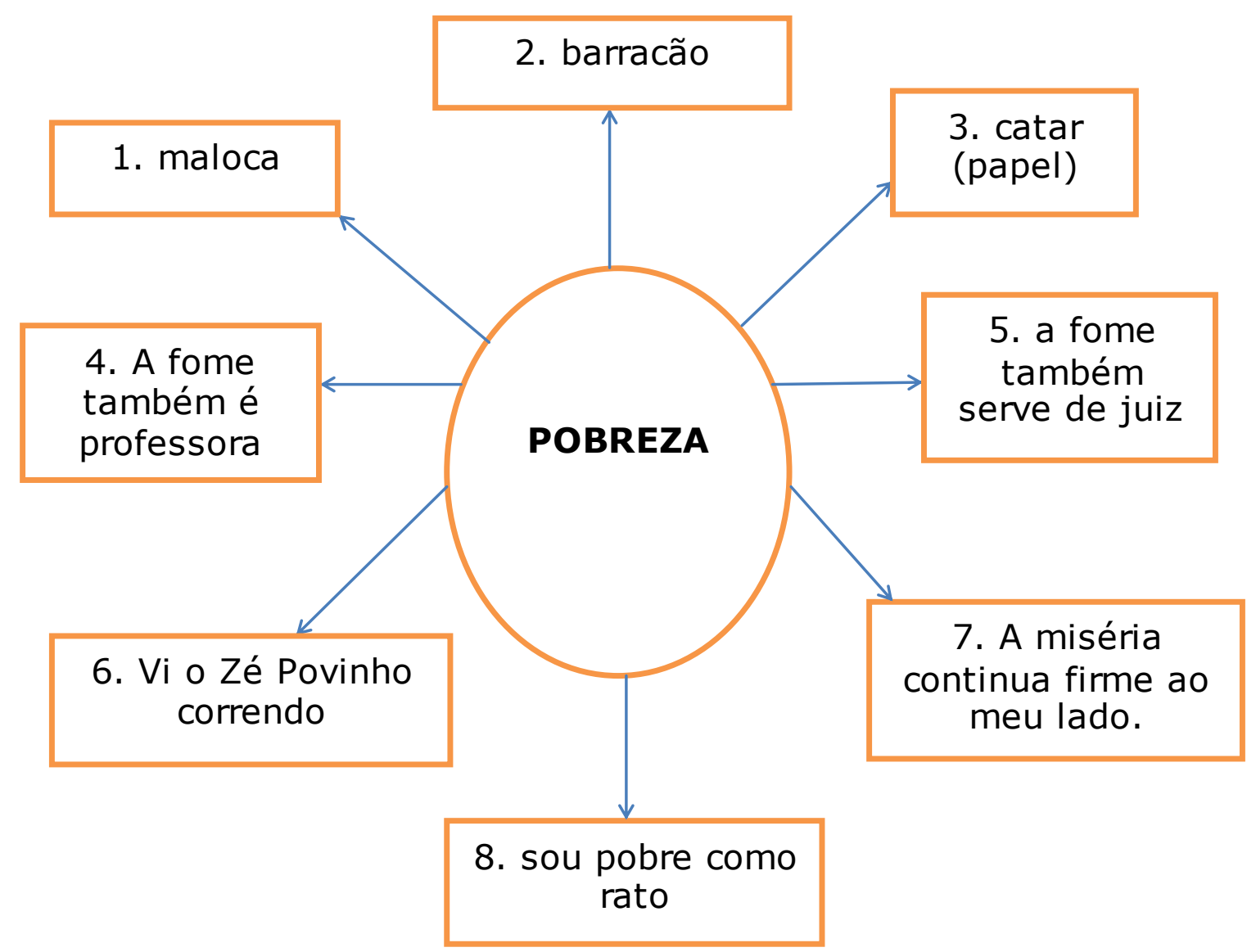

Seguem os exemplos em contexto:

18 de julho de 1955 (...) A Sílvia pediu-me para retirar o seu nome do meu livro. Ela disse:

- Você é mesmo uma vagabunda. Dormia no Albergue Noturno. O seu fim era acabar na maloca.

Eu disse:

- Está certo. Quem dorme no Albergue Noturno são os indigentes. Não tem recurso e o fim é mesmo nas malocas, e você, que diz nunca ter dormido no Albergue Noturno, o que veio fazer aqui na maloca? Você era para estar residindo numa casa própria. Por que a sua vida rodou igual a minha?

Ela disse:

- A única coisa que você sabe fazer é catarpapel.

Eu disse: 
- Cato papel. Estou provando como vivo! (p. 21, linhas 16-29)

27 de julho de 1955 (...) O Senhor Ireno disse-me que esta noite houve roubo na favela. Que roubaram roupas da Dona Florela e mil cruzeiros de D. Paulina. O meu barracão também está sendo visado. Duas noites que não saio para catar papel. (p. 28, linhas 23-26)

9 de maio de 1958 .... Eu cato papel mas não gosto. Então eu penso: faz de conta que eu estou sonhando. (p. 30, linhas 26-27)

10 de maio de 1958 (...) O Brasil precisa ser dirigido por uma pessoa que já passou fome. A fome também é professora.

Quem passa fome aprende a pensar no próximo, e nas crianças. (p. 31, linhas 1215)

3 de junho de 1958 (...) Quando o Nilton começou passar fome, foi com a mãe. Pensei: a fome também serve de juiz. (p. 53, 32-33)

27 de julho de 1958 (...) Eu estava girando com os cadernos na mão quando ouvi vozes alteradas. Fui ver o que era, percebi que era briga. Vi o Zé Povinho correndo. Briga é um espetáculo que eles não perdem. Eu já estou tão habituada a ver brigas que já não impreciono. (p. 100, linhas 21-25)

23 de setembro de1958 (...) Percebi que entre os ricos há sempre uma divergência por questões de dinheiro. Não posso esclarecer estas questões porque sou pobre como rato. (p. 119, linhas 11-13)

11 de dezembro de 1958 ...Comecei queixar para a Dona Maria das Coelhas que o que eu ganho não dá para tratar os meus filhos. Eles não tem roupas nem o que calçar. $\mathrm{E}$ eu não paro um minuto. Cato tudo que se pode vender e a miséria continua firme ao meu lado. (p. 137, linhas 12-16)

Um leitor mais exigente apontaria a presença de clichês na enunciação de Quarto de despejo. A pobreza e suas vicissitudes decorrentes são tematizadas com metáforas e comparações de uso bastante previsível.

Como não seria? A caracterização da fome se faz com a interligação de lexias de significados afins. Trata-se de um clichê inevitável e de ligações inescapáveis: zé povinho $\rightarrow$ maloca, barracão $\rightarrow$ catar papel e outras "coisas" $\rightarrow$ passar fome $\rightarrow$ ser pobre $\rightarrow$ a persistência da miséria. Todos esses elementos criam um quadro triste do contexto em que vive 
Carolina e reforçam ainda mais a linguagem popular de seu relato.

\subsubsection{2 - A favela}

Umbilicalmente ligada ao domínio semântico da pobreza, a favela, lugar de onde o enunciador constrói seu discurso, está longe de ser um espaço privilegiado, pois é um local de sofrimento, caracterizado por expressões ásperas que traduzem a vida difícil e sem perspectivas dos seus moradores.

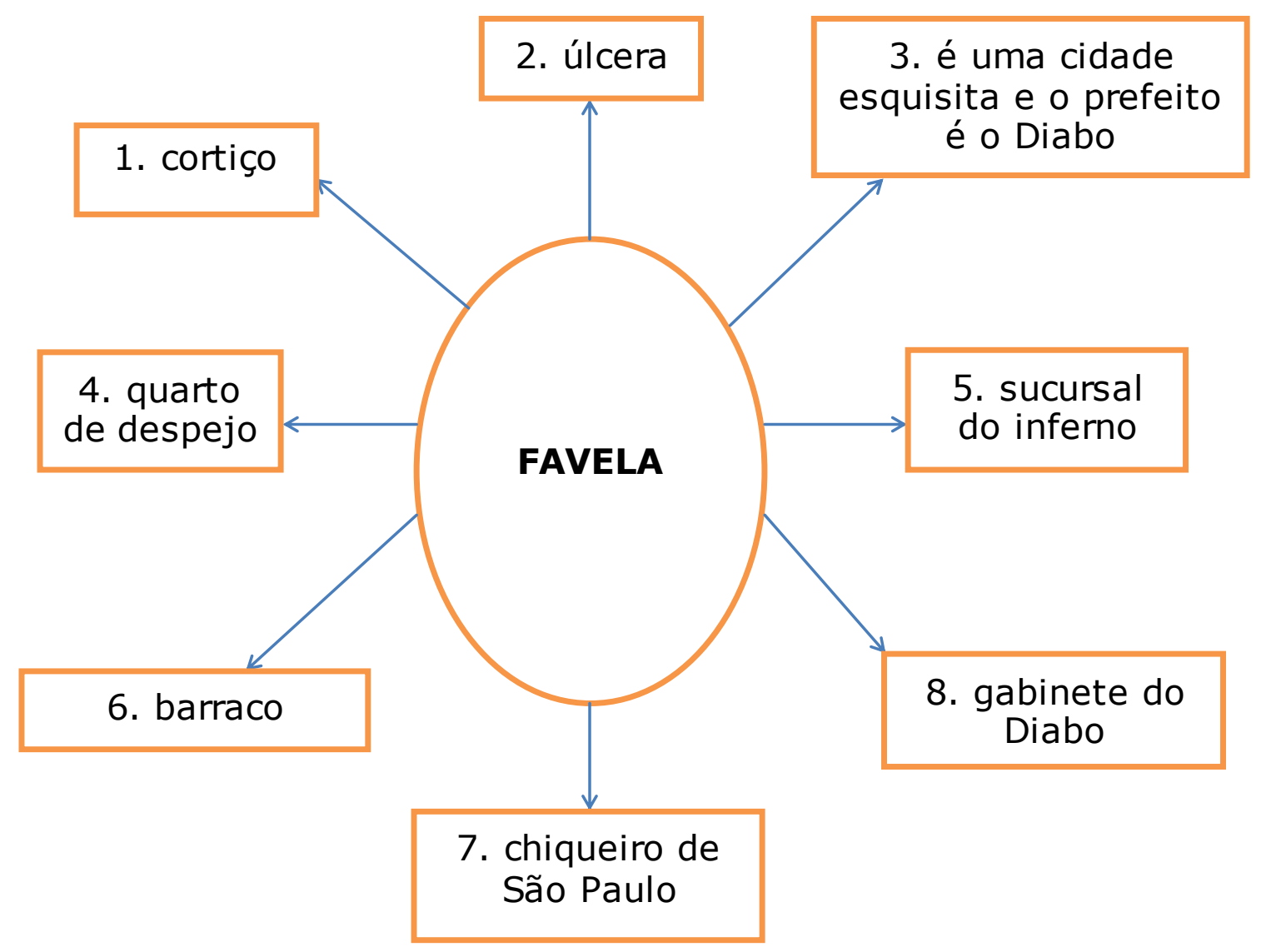

Seguem os exemplos em contexto:

22 de julho de 1955 (...) Virei na rua Frei Antônio Galvão. Quase não tinha papel. A D. Nair Barros estava na janela. Eu falei que residia em favela. Que favela é o pior cortiço que existe. (p. 26, linhas 23-26) 
7 de julho de 1958 (...) Quando eu vou na cidade tenho a impressão que estou no paraízo. Acho sublime ver aquelas mulheres e crianças tão bem vestidas. Tão diferentes da favela. As casas com seus vasos de flores e cores variadas. Aquelas paisagens há de encantar os olhos dos visitantes de São Paulo, que ignoram que a cidade mais afamada da América do Sul está enferma. Com as suas úlceras. As favelas. (p. 84, linhas 18-24)

10 de julho de 1958 (...) Fui buscar uma lata de água e uma senhora estava lamentando:

- Se eu fosse jovem eu não residia nesta favela nem um dia. Mas eu já estou velha. E velho não se governa.

Aqui nesta favela a gente vê coisa de arrepiar os cabelos. A favela é uma cidade esquisita e o prefeito daqui é o Diabo. E os pinguços que durante estão oculto a noite aparecem para atentar.

Percebo que todas as pessoas que residem na favela odeiam o lugar. (p. 90, linhas 13-22)

27 de dezembro de 1958 ...Eu cancei de escrever, adormeci. Despertei com uma voz chamando Dona Maria. Fiquei quieta, porque eu não sou Maria. A voz dizia:

- Ela disse que mora no número 9.

Levantei de mau humor e fui atender. Era o senhor Dario. Um senhor que eu fiquei conhecendo na eleição. Eu mandei o senhor Dario entrar. Mas fiquei com vergonha. $O$ vaso noturno estava cheio.

O senhor Dario ficou horrorizado com a primitividade em que eu vivo. Ele olhava tudo com assombro. Mas ele deve aprender que a favela é o quarto de despejo de São Paulo. E que eu sou uma despejada. (p. 141, linhas 14-25)

7 de maio de 1959 ...Lavei todas as roupas. Jurei nunca mais matar pouco na favela. Eu estou tão nervosa que recordei o meu próprio provérbio: não há coisa pior na vida do que a própria vida.

Favela, sucursal do Inferno, ou o próprio Inferno. (p. 158, linhas 08-12)

18 de junho de 1959 (...) O barraco da Aparecida é o ponto para reunir os pinguços. Beberam e depois brigaram. (p. 166, linhas 28-29)

6 de julho de 1959 O senhor Manoel saiu. E eu fiquei deitada. Depois levantei e fui carregar água. Que nojo. Ficar ouvindo as mulheres falar. Falaram da D., que ela namora qualquer um. Que a R., irmã do B., pertence aos homens.

Falamos do J. P., que quer amasiar-se com a sua filha I. (...) Ele mostra para a filha e convida...

-Vem, minha filha! Dá para o seu papaizinho! Dá... só um pouquinho. 
Eu já estou cansada de ouvir isto, porque infelizmente eu sou visinha do J.P. (...) É um homem que não pode ser admitido numa casa onde tem crianças.

Eu disse:

É por isso que eu digo que a favela é o chiqueiro de São Paulo.

Enchi minha lata e zarpei, dando graças a Deus por sair da torneira. A C. disse que pediu dinheiro ao seu pai para comprar um par de sapatos, e ele disse:

Se você me der a.... eu te dou 100. Ela deu. E ele deu-lhe só 50. Ela rasgou o dinheiro e a I. catou os pedaços e colou.

Porisso que eu digo que a favela é o Gabinete do Diabo. (p. 170, linhas 01-25)

Embora tais exemplos falem por si mesmos, é digno de nota observar como a favela é tematizada em Quarto de despejo: a favela é "úlcera", "cidade esquisita", "quarto de despejo", "sucursal do inferno", "chiqueiro", "gabinete do Diabo".

É, também, o lugar onde as pessoas não moram em casas, mas em "barracos". Em nenhum momento a narradora se refere às habitações improvisadas da favela com o lexema "casa". A este respeito é sintomática a seguinte passagem: "Cheguei na favela: eu não acho jeito de dizer cheguei em casa. Casa é casa. Barracão é barracão." (p. 48, grifo nosso)

Observamos como essas expressões se interligam semanticamente, embora estejam em pontos diversos da narrativa. Todas são empregadas para caracterizar a favela como um lugar sombrio, péssimo e impróprio para a vida das pessoas.

5.2.2 - Vocábulos de feição culta ou preciosa na linguagem narrativa de Quarto de despejo

De modo particularmente notável e não condizente com a escolaridade mínima da autora, entre as palavras e expressões de origem popular se sobressai um número expressivo de lexemas cultos ou preciosos, frutos da leitura e de sua cultura paraescolar. 
Ao lado do registro de um número bastante elevado de vocábulos de uso popular, que se fazem presentes tanto na linguagem narrativa quanto na fala das personagens, Carolina Maria de Jesus revela uma sofisticação vocabular sui generis.

Há em Quarto de despejo muitos vocábulos de feição culta, tais como agrura, asqueroso, atribulada, benéfico, bradar, cálido, contemplar, contingência, des/umbrantes, despir-se, deteriorados, deturpar, dissipar, ébrio, esquife, estrepitoso, excremento, fustigar, galgar, hediondo, hediondo, impelido, indolente, infausto, infortúnio, instigar, instigar, manusear, meretriz, mesclar-se, moléstia, monótono, notívago, perpassar, primitivismo, prófugo, pungente, pungente, rascoa, rejubilarse, renegar, residir, resoluto, rumor, sapiência, sapiência, senso, sinfonia, suplício, tépida, utensílio, vasculhar, zarpar, entre muitos outros.

Como não é nossa intenção fazer um levantamento exaustivo, veremos apenas uma pequena amostragem, analisando algumas dessas ocorrências em contexto. Todos os exemplos a seguir foram colhidos apenas na primeira parte do diário, com entradas referentes ao mês de julho de 1955:

17 de julho (...) Está circulando rumor que eu estou grávida! E eu, não sabia! (p. 15, linhas 30-31)

19 de julho (...) Estive revendo os aborrecimentos que tive esses dias. Suporto as contingências da vida resoluta. Eu não consegui armazenar para viver, resolvi armazenar paciência. (p. 19, linhas 26-28)

19 de julho (...) Nas favelas, as jovens de 15 anos permanecem até a hora que elas querem. Mescla-se com as meretrizes, contam suas aventuras. Há os que trabalham. E há os que levam a vida a torto e a direito. As pessoas de mais idade trabalham, os jovens é que renegam o trabalho. (p. 20, linhas 28-32)

19 de julho (...) O dia de hoje me foi benéfico. As rascoas da favela estão vendo eu escrever e sabe que é contra elas. (p. 22, linhas 17-19)

20 de julho (...) O senhor Ismael, quando não está alcoolizado, demonstra sua sapiência. (p. 22, linha 36 - p. 23, linha 01) 
20 de julho (...) Refleti: preciso ser tolerante com os meus filhos. Eles não têm ninguém no mundo a não ser eu. Como é pungente a condição de mulher sozinha sem homem no lar. (p. 24, linhas 04-06)

22 de julho (...) A primeira coisa que faço é abrir a janela e contemplar o espaço. (p. 27, linhas 01-02)

24 de julho (...) A mãe ouvia e não repreendia. São as mães que instigam. (p. 28, linhas 10-11)

Como, naturalmente, a editoração eliminou vários trechos do diário de Carolina, muitos vocábulos de feição culta, alguns até mesmo raros e preciosos, ficaram de fora do livro e podem ser recuperados pela obra Meu Estranho Diário, mencionada anteriormente neste estudo:

07 de novembro de 1958 (...) É muito mais bonito ver uma mulher disposta do que ver uma letárgica igual a tartaruga. - Eu não gosto das mulheres preguiçosas. ( $p$. 54, linhas 11-13)

22 de novembro de 1958 (...) Se é que o diabo predomina na Natureza, a Leila é do seu clã. Quando eu retornava com o tambor de ferro na cabeça, vi uns prófugos. Pensei: Ah! Meu Deus! Já não basta os que tem na favela? (p. 93, linhas 03-05)

25 de novembro de 1958 (...) A Deolinda está nervosa porque o Orlando the cortou a luz - Favelado é herva daninha. Favelado é pior do que a lepra - Ele não considera o seu colega de infortúnio. Esse tal Orlando apareceu aqui não faz um ano. É semi-analfabeto. Mas prevalece do que sabe e quer ser o tal.

Ele é branco. É amasiado com uma preta que pode ser sua avó. - É um branco rampeiro. Deolinda foi dar parte dele. Ele cortou a luz porque ela está Ihe devendo um mês.

Eu revolto com estas arbitrariedade. A Deolinda Deolinda é atrabiliosa e já desacatou Ihe. (p. 95, linha 25 - p. 96, linha 02)

27 de novembro de 1958 (...) Contemplei a paisagem. Vi as flores roxas que adornava o vergel, a cor madrasta, a cor da agrura que está adornando os corações dos brasileiros famintos. (p. 99, linhas 01-03)

30 de novembro de 1958 (...) Quando eu estava na torneira vi as notívagas chegar - Fico olhando a mocidade dissipando a saúde. (p. 103, linhas 29-30)

2 de dezembro de 1958 (...) Saí para fora enquanto ele comprava os doces que a Vera indicava nos vidros. Eu lhe agradeci e disse que a Vera quando pede algo é com tenacidade. Que eu quero ver se quando ela começar a trabalhar vai ser com tenacidade. (p. 105, linhas 30-34) 
4 de dezembro de 1958 (...) Ela começou a falar do seu infausto consórcio ouvindo-a percebi que a união de dois entes às vezes acarreta mil e um sofrimentos para ambos. (p. 115, linhas 01-03)

4 de dezembro de 1958 (...) Cheguei à conclusão que quem reside nestes núcleos sórdidos pouco a pouco vai se transformando. Quando eu vim residir aqui na favela, eu era suave. Gostava só de agradar.

Atualmente sou pior do que a soda, pior do que a ortiga. (p. 115, linhas 18-22)

Ao contrário de grande parte do léxico popular, todos os casos ocorrem na voz da narradora. Nunca se verá um personagem da favela empregando tais lexemas. Apenas Carolina, a narradora, a "poeta", é quem faz uso desse registro "clássico".

É o que chamamos de "paixão pela palavra". Carolina, mulher negra e pobre, percebeu, desde a infância, que a leitura e a escrita fazem parte do universo dos poderosos. É nesse universo que ela pretendia entrar por meio da literatura.

A partir de um repertório literário pautado, principalmente, por autores do século XIX, Carolina formou um vocabulário linguisticamente requintado, ao lado de um vocabulário popular e de uso informal.

Impressionada pela "beleza" das palavras, Carolina não hesita em demonstrar, pelo emprego de um leque vocabular não usual, seu conhecimento das letras, mesmo que em alguns momentos esse conhecimento se mostre incipiente ou semanticamente equivocado.

Mais do que meramente inventariarmos tais registros, é necessário tentarmos indagar o porquê desse registro. Por que uma mulher "favelada", de quase nenhuma instrução formal, usa vocábulos como "prófugos" ou "rascoas", por exemplo?

A intenção de Carolina era conquistar o sucesso como escritora, adentrar o universo da literatura, da cultura, e ser reconhecida. Tais vocábulos, frutos de suas leituras e de suas observações da sociedade letrada, adquirem este papel: demonstrar aos seus enunciatários que ela não era uma pessoa comum, sem esclarecimento e sem cultura. 
Aquele seria o seu passaporte para a sociedade letrada. O problema é que em vários momentos as palavras parecem ser empregadas descoladas de seu real sentido e parecem ocorrer apenas pelo seu aspecto sonoro, pela sua "imponência" ou "beleza" ante a percepção da autora.

A despeito de suas origens humildes, Carolina usa lexemas cultos e preciosos como fruto de uma intensa leitura de textos literários, pondo em evidência uma memória discursiva atualizada pela "beleza" das palavras e pelo seu uso por pessoas de status.

A expressividade das escolhas lexicais de Quarto de despejo se dá justamente pela permanente "colisão" dos níveis de registro: ao lado de lexias de uso popular, a narrativa contempla palavras de gosto raro, advindas da literatura anterior ao século $X X$, frutos evidentes das múltiplas leituras de Carolina.

Embora em alguns momentos o uso pareça despropositado, esse repertório de Carolina Ihe permitiu construções bastante expressivas, como as expressões com que metaforizou a favela: quarto de despejo, gabinete do Diabo, cidade esquisita, sucursal do inferno, chiqueiro de São Paulo. São metáforas altamente expressivas, porque inusitadas para um enunciador com escolaridade praticamente nula.

Mesmo que Audálio Dantas pretendesse abortar as pretensões literárias de Carolina, no Quarto de despejo elas são muito evidentes. Apesar de clichês inevitáveis e de usos equivocados, Quarto de despejo demonstra que a variedade popular pode ser tão expressiva e estilisticamente criativa quanto a variedade culta. 


\section{CONCLUSÃO}

Refletindo a ideia de proximidade (ainda que virtual ou na mente da narradora), a escrita de Carolina não é desprovida de intenção. A enunciação não é uma atividade alienada: a narradora concebe um público a quem se dirige e a quem quer impressionar, comover ou em quem quer despertar qualquer tipo de emoção. Ninguém escreve com o intuito de arquivar sua produção, sem conceber que alguém a leia. E nesse ato de linguagem as palavras assumem um papel crucial, pois jamais são neutras, conforme bem pontua Citelli:

Se as palavras, por exemplo, possuem dimensão mais ou menos
neutra quando estão em estado de dicionário, ao se
contextualizarem, passam a expandir valores, conceitos, pré-
conceitos. Viveremos e aprenderemos em contato com outros
homens e mulheres, mediados pelos signos, que irão nos informar
e formar. Os signos serão por nós absorvidos, transformados e
reproduzidos, criando um circuito de formação e reformulação de
nossas consciências. (...) As palavras, no contexto, perdem sua
neutralidade e passam a indicar aquilo a que chamamos
propriamente de ideologias. (CITELLI, 2007, p. 30-31)

A enunciação não é, portanto, uma atividade neutra e desintencionada. O enunciador faz uso do léxico com (nem sempre claras para o leitor) "intenções de comunicação". (CALÇADA, 1994, p. 854).

Um texto como Quarto de despejo, que é uma narrativa escrita em primeira pessoa e que relata o quotidiano, desperta múltiplos questionamentos, até certo ponto conflitantes, e que não caberiam neste espaço.

Preti faz alusão ao "discurso híbrido ${ }^{31 ", ~ i s t o ~ e ́, ~ u m ~ d i s c u r s o ~ e m ~ q u e ~ a ~}$ linguagem culta e a popular se mesclam. (PRETI, 2008, p. 279) Vemos esse hibridismo na linguagem de Quarto de despejo com bastante clareza, e não nos parece que seja um elemento casual. No caso de Carolina, o

31 Embora no texto em questão Preti tenha analisado um corpus de textos acadêmicos produzidos por jovens universitários, suas conclusões podem ser aplicadas ao nosso estudo, visto que embora produzido por um enunciador distinto, possui características semelhantes. 
emprego de um vocábulo de feição popular confere um grau de legitimidade ao texto, no sentido de verossimilhança: trata-se do repertório da autora e daqueles com quem conviveu e a quem dá voz por meio de sua narrativa. Os vocábulos cultos (ora preciosos) também buscam a legitimidade, mas noutro sentido: buscam construir junto ao público a imagem da escritora, da autora que conhece a língua apesar das origens e da trajetória errática.

Carolina era uma escritora de letramento parcial, por mais paradoxal que isto seja. O que causa surpresa é alguém com essa formação empregar termos raros e preciosos, frutos de muitas leituras, principalmente literárias. Carolina foi empregada doméstica em casas de famílias ricas na cidade de São Paulo, onde teve acesso às bibliotecas dos patrões; também recolhia livros velhos entre os papéis e sucatas que encontrava pelas ruas. Sua infância dolorosa, a perspectiva de que a cultura pertence aos poderosos, a miséria e o preconceito racial subjacente incutiram em Carolina um encantamento no sentido de ver que as pessoas de status social usam palavras "bonitas", e ela, para obter o seu quinhão de um mundo civilizado e letrado, precisava se apropriar desse repertório cultural.

O léxico popular reforça a imagem da veracidade, do relato verdadeiro que nasce num estrato social desprivilegiado e cuja linguagem o reflete. Por outro lado, o léxico culto alude à memória discursiva do narrador, que tem a intenção de projetar a imagem do escritor, do literato.

Apesar da nossa intenção de elencar características que sirvam de parâmetro mínimo para analisar o léxico de feição popular em contraposição ao léxico de feição culta, a própria ocorrência de termo de uso popular não é fácil de elencar ou caracterizar, devido à falta de fronteiras claras entre as modalidades. Nem sempre é possível determinar a que nível de registro pertence um vocábulo específico. O contexto de produção determinará, de modo nem sempre preciso ou satisfatório, se um vocábulo é culto, popular ou se ocupa uma posição intermediária entre 
as duas modalidades. Acreditamos que os vulgares, os gírios e os preciosos são os mais "delimitáveis", facilmente reconhecidos pelos usuários da língua.

As rubricas antepostas pelos dicionários servem de balizamento geral e preliminar para determinar a modalidade de uma palavra ou expressão, se é culta (conceptualmente escrita) ou popular (conceptualmente falada). Ademais, o contexto de produção em que o vocabulário está inserido servirá para indicar a concepção: uso familiar, injurioso, obsceno, etc.

Mesmo cientes da multiplicidade de variáveis envolvidas, supomos que o aspecto linguístico da obra contribua, ainda que indiretamente, para o esquecimento de Carolina: seu português popular não é reconhecido como veículo legítimo para a expressão literária. Não no sentido que ela queria. Para Lajolo, Carolina

$$
\begin{aligned}
& \text { queria arrombar a literatura e, arrombando-a, transformá-la em } \\
& \text { degraus de acesso a níveis sociais populares. O projeto de } \\
& \text { ascensão era claramente equivocado, já se vê. Mas o equívoco se } \\
& \text { dava não porque a literatura não possa servir de pedestal para } \\
& \text { ascensão social, pois que ela já serviu e continua servindo para } \\
& \text { isso, em muitos casos. Mas equivocado porque, enquanto alavanca } \\
& \text { social, a literatura cobra um preço alto dos aspirantes a sócios de } \\
& \text { seu clube exclusivo... Preço talvez alto demais para uma mulher } \\
& \text { negra e pobre que recusava sempre os scripts que lhe reservava a } \\
& \text { sociedade branca culta. Não compreendendo o câmbio em que o } \\
& \text { pagamento do ingresso deveria ser feito, não é de estranhar que } \\
& \text { Carolina tenha acabado condenada à pobreza e à solidão. } \\
& \text { (LAJOLO, 1996, p. 60) }
\end{aligned}
$$

E até hoje, decorridos tantos anos da publicação, Quarto de despejo ainda é editado e vendido mas como uma curiosidade, como uma peça folclórica, com a velha e monocórdica ressalva dos "erros gramaticais".

Quando Audálio descobriu Carolina na favela do Canindé, de certa maneira selou um destino dúbio para a autora: ao editorar o livro, preferiu não fazer correções ortográficas, nem morfossintáticas. Por que terá feito isso? Para mostrar a suposta vivacidade da linguagem popular? Ou para resguardar a sua imagem e não ser acusado de promover uma farsa?

O diário de Carolina constitui um paradoxo: ao mesmo tempo em 
que serviu de curiosidade, de documento vivo da miséria, sua escrita fora dos padrões cultos tradicionais o condenou a uma posição desprestigiada como texto literário.

Mas essa questão ainda vai além dos limites deste trabalho e requer outras abordagens teóricas, com maior profundidade. 


\section{APÊNDICE}

\section{Glossário}

A

APOSENTADO, adj. - Homem que não tem mais atividade sexual.

ARRANJAR MULHER, v. - Conquistar parceira para relação eventual.

ARREPIAR OS CABELOS, v. - Espantar, chocar.

B

BACALHAU - feder -. Exalar mau cheiro por falta de banho.

BARRACO (ÃO), s.m. - habitação improvisada, feita de madeira.

BATE-FUNDO, s.m. barulho: "conflito, briga, resistência à ação policial". (VIOTTI) Em QD, ocorre na acepção de "barulho".

BATER CARTEIRA - "furtar". (NASCENTES, DG.)

BOBAGEM - Fazer -. Praticar ato sexual.

BOSTA, s.f. - fezes; excremento humano ou animal.

BUCETA (BOCETA), s.f. - A vulva. Chupar boceta, v. ato de buscar e dar prazer sexual com a boca e a língua na vulva da mulher. Cunilíngua, minete.

$\mathrm{C}$

CACETE, adj. - que ou o que provoca tédio, enfado, aborrecimento; maçante

CAGAR, v. - Defecar

CANA, entrar em, v. - Ser preso.

CHUPADOR, s.m. - Aquele que pratica coito oral.

CUPINCHA, s.m. - Apaniguado, cúmplice. 
D

DAR, v. - Fazer sexo com.

$E$

EMBRULHAR, v. - Enganar.

ENCRENCA, s.f. - situação confusa, complicada, perigosa

ESPELUNCA, s.f. - esconderijo de bandidos; covil, antro

$\mathrm{F}$

FODA, dar uma; FODER, v. - Copular, ter relações sexuais.

FRESCO, adj. Homossexual.

FUÁ, s.m. - confusão geral. (VIOTTI)

L

LENGA-LENGA, s.f. - o que é demorado, fastidioso.

LIXEIRA, s.m. - Forma empregada em Quarto de despejo como fem. de "lixeiro".

M

MALOCA, s.f. - casa muito pobre, rústica; choupana, rancho, barracão MANDA-CHUVA, s.m. - indivíduo com importância e influência; magnata MÃO EM MÃO, Passar de, v. - Ter vários parceiros sexuais.

MERDA, s.f. - fezes, excremento humano ou animal.

MUAMBA, s.f. - mercadoria, peça, objeto contrabandeado; contrabando. Em Quarto de despejo, pequenos objetos. 
NORTE, s.m. - O NE (Nordeste) brasileiro.

NORTISTA, s.m. - Quem nasceu na região Nordeste.

$\mathrm{P}$

PORCARIA, fazer, v. - Fazer sexo com.

PUTO, s.m.- Homossexual

$\mathrm{S}$

SHOW, dar, v. - Provocar escândalo.

SOVA, dar. - Bater em alguém.

SURURU, s.m. - confusão, barulho.

$\mathrm{V}$

VAGABUNDO, adj. - Indivíduo vadio. VAGABUNDAR, v. - Vadiar.

VIDA MANSA, ter ou estar com a, v. - Estar financeiramente tranquilo.

Z

ZÉ-POVINHO, s.m. - Indivíduo comum, sem importância.

ZÉ-QUALQUER, s.m. - Indivíduo comum, sem importância. 


\section{REFERÊNCIAS BIBLIOGRÁFICAS}

\section{Gerais}

ALÉONG, Stanley. Normas linguísticas, normas sociais: uma perspectiva antropológica. In: BAGNO, Marcos (Org.). Norma linguística. São Paulo: Loyola, 2001.

AUROUX, Sylvain. A revolução tecnológica da gramatização. Trad. Eni P. Orlandi. Campinas: Editora da UNICAMP, 1992.

BALLY, Charles. El lenguaje y la vida. Trad. Amado Alonso. Buenos Aires: Losada, 1941.

BAKHTIN, Mikhail. Estética da criação verbal. Trad. Maria Ermantina de Almeida Prado Galvão. São Paulo: Martins Fontes, 1992.

BARBOSA, Maria Aparecida. Léxico, produção e criatividade: processos do neologismo. São Paulo: Global, 1981.

BARROS, Mariana L. P. de. A arquitetura das memórias: um estudo do tempo no discurso autobiográfico. Dissertação de Mestrado em Semiótica e Linguística Geral. São Paulo: DL-FFLCH-USP, 2006.

BENVENISTE, Émile. Problemas de Linguística Geral I. Trad. Maria da Glória Novak e Maria Luísa Neri. 4a ed. Campinas: Pontes, 1995.

. Problemas de Linguística Geral II. Trad. Eduardo Guimarães et al. Campinas: Pontes, 1989.

BRAIT, Beth. A personagem. 8.ed. São Paulo: Ática, 2006.

BIDERMAN, Maria Thereza Camargo. Teoria linguística: teoria lexical e linguística computacional. São Paulo: Martins Fontes, 2001.

CABELLO, Ana Rosa Gomes. A gíria como linguagem literária em contos de João Antônio. Bauru (SP): Universidade do Sagrado Coração, 1988. 
CALÇADA, Guiomar Fanganiello. A seleção lexical e a construção do sentido. Anais do IX Encontro Nacional da Anpoll. Vol. 2. Caxambu (MG): ANPOLL, 1994.

CÂMARA JR., Joaquim Mattoso. Contribuição à Estilística Portuguesa. 2a ed. Rio de Janeiro: Organização Simões, 1953.

CARDOSO, Elis de Almeida. Escolhas lexicais: a caracterização de personagens femininas no discurso literário. Linha d'Água, n. 26 (1), p. 15-28. São Paulo: FFLCH-USP, 2013.

CARVALHO, Alfredo Leme Coelho de. Foco narrativo e fluxo da consciência. São Paulo: Editora Unesp, 2012.

CITELLI, Adilson. Linguagem e persuasão. 3a. ed. São Paulo: Ática, 1988.

GARCIA, Othon. Comunicação em prosa moderna. 17 ed. Rio de Janeiro: Fundação Getúlio Vargas, 1997.

GINZBURG, Jaime. Impacto da violência e constituição do sujeito: um problema da teoria da autobiografia. In: GALLE, Helmut et alii. Em primeira pessoa: abordagens de uma teoria da autobiografia. São Paulo: Annablume / Fapesp / FFLCH-USP, 2009.

$\mathrm{KOCH}$, Ingedore G. V. A inter-ação pela linguagem. 10a. ed. São Paulo: Contexto, 2007.

. Especificidade do texto falado. In: JUBRAN, Clélia Cândida A. S.; $\mathrm{KOCH}$, Ingedore G. V. Gramática do português culto falado no Brasil. Campinas: Editora da UNICAMP, 2006.

$\mathrm{KOCH}$, Peter; OESTERREICHER, Wulf. Linguagem da imediatez linguagem da distância: oralidade e escrituralidade entre a Teoria da Linguagem e a História da Língua. Trad. Hudinilson Urbano e Raoni Caldas. Linha d'Água, n. 26 (1), p. 153-174. São Paulo: FFLCH-USP, 2013.1

LEITE, Lígia Chiappini Moraes. O foco narrativo. 10.ed. São Paulo: Ática, 2005. 
MAINGUENEAU, Dominique. Discurso literário. Trad. Adail Sobral. São Paulo: Contexto, 2006.

MARCUSCHI, Luiz Antônio. Da fala para a escrita: atividades de retextualização. 8a. ed. São Paulo: Cortez, 2007.

MARTINS, Nilce Sant'Anna. A figura do narrador nas Primeiras Estórias, de Guimarães Rosa. In: URBANO, Hudinilson et al (Orgs.). Dino Preti e seus temas: oralidade, literatura, mídia e ensino. São Paulo: Cortez, 2001.

Introdução à Estilística: a expressividade na língua portuguesa. 3a ed. rev. e aum. São Paulo: T. A. Queiroz, 2000.

OESTERREICHER, Wulf. Pragmática del discurso oral. In: BERG, Walter Bruno; SCHÄFFAUER, Markus Klaus. Oralidad y Argentinidad: estudios sobre la función del lenguaje hablado en la literatura argentina. Tübbingen: Gunter Narr Verlag, 1997.

- Lo hablado em lo escrito. Reflexiones metodológicas y aproximación a uma tipologia. In: KOTSCHI, Thomas; OESTERREICHER, Wulf; ZIMMERMANN, Klaus. (Eds.) El español hablado y la cultura oral en España e Hispanoamérica. Frankfurt am Main: Vervuert; Madrid: Iberoamericana, 1996.

PINTO, Edith Pimentel. O português popular escrito. $3^{a}$ ed. São Paulo: Contexto, 2001.

A língua escrita no Brasil. São Paulo: Ática, 1986.

PIRES, Orlando. Manual de teoria e técnica literária. Rio de Janeiro: Presença/INL-MEC, 1981.

POTTIER, Bernard; AUDUBERT, Albert; PAIS, Cidmar Teodoro. Estruturas linguísticas do Português. São Paulo: Difusão Europeia do Livro, 1972. PRETI, Dino. A linguagem proibida: um estudo sobre a linguagem erótica. São Paulo: LPB, 2010.

- Linguagem, status e papéis sociais. In: CAVALIERE, Ricardo (Org.). Entrelaços entre textos: miscelânea em homenagem a Evanildo 
Bechara. Rio de Janeiro: Nova Fronteira, 2008.

- Variedades lexicais em discursos marginais: a gíria de grupo. In:

PRETI, Dino (Org.). Oralidade em diferentes discursos. São Paulo: Humanitas, 2006.

- Estudos de língua oral e escrita. Rio de Janeiro: Lucerna, 2004.

Sociolinguística: os níveis de fala. 9a ed. São Paulo: Edusp, 2003.

A gíria e outros temas. São Paulo: T. A. Queiroz, 1984.

SAPIR, Edward. A linguagem: introdução ao estudo da fala. São Paulo: Perspectiva, 1980.

URBANO, Hudinilson. A frase na boca do povo. São Paulo: Contexto, 2011.

. Usos da linguagem verbal. In: PRETI, Dino (Org.). Oralidade em diferentes discursos. São Paulo: Humanitas, 2008.

A Expressividade na língua falada de pessoas cultas. In: PRETI, Dino (Org.) $O$ discurso oral culto. 3a ed. São Paulo: Humanitas, 2005.

. Oralidade na literatura: o caso Rubem Fonseca. São Paulo: Cortez, 2000.

VILELA, Mário. Estudos de lexicologia do português. Coimbra: Almedina, 1994.

. Estruturas léxicas do português. Coimbra: Almedina, 1979.

Obras de referência

AULETE, F. J. Caldas. Dicionário contemporâneo da Língua Portuguesa. Edição brasileira. 4a․ ed. Rio de Janeiro: Delta, 1958. 
AZEREDO, José Carlos de. Gramática Houaiss da Língua Portuguesa. São Paulo: Publifolha, 2008.

BORBA, Francisco S. et alii (Org.). Dicionário UNESP do português contemporâneo. São Paulo: Ed. da UNESP, 2004.

CÂMARA JR., Joaquim Mattoso. Dicionário de filologia e gramática referente à língua portuguesa. Rio de Janeiro: J. Ozon, 1964.

COUTINHO, Ismael de Lima. Gramática histórica. 7a. ed. Rio de Janeiro: Ao Livro Técnico, 1976.

FERREIRA, Aurélio B. $H$. Novo dicionário Aurélio da língua portuguesa. 4a . ed. Curitiba: Positivo, 2010.

. Novo dicionário da língua portuguesa. Rio de Janeiro: Nova Fronteira, 1975.

HOUAISS, Antônio. Dicionário Houaiss da língua portuguesa. Rio de Janeiro: Objetiva, 2001.

NASCENTES, Antenor. A gíria brasileira. Rio de Janeiro: Acadêmica, 1953.

REIS, Carlos; LOPES, Ana Cristina Moita. Dicionário de teoria da narrativa. São Paulo: Ática, 2002.

SERRA e GURGEL, J. B. Dicionário de gíria: O equipamento linguístico falado do brasileiro. 5a ed. Brasília (DF): Valci Editora, 1998.

VIOTTI, Manuel. Novo dicionário da gíria brasileira. $3^{a}$ ed. Rio de Janeiro: Tupã, 1958.

\section{Da autora}

JESUS, Carolina Maria de. Meu estranho diário. Org. José Carlos Bom Meihy e Robert M. Levine. São Paulo: Xamã, 1996.

Antologia pessoal. Org. José Carlos Sebe Bom Meihy. Rev. 
Armando Freitas Filho. Rio de Janeiro: Editora da UFRJ, 1996.

Diário de Bitita. Rio de Janeiro: Nova Fronteira, 1986.

. Casa de alvenaria: diário de uma ex-favelada. Rio de Janeiro: Francisco Alves, 1961.

Quarto de despejo: diário de uma favelada. Rio de Janeiro: Francisco Alves, 1960.

\section{Sobre a autora}

DANTAS, Audálio. Casa de alvenaria - história de uma ascensão social. In: JESUS, Carolina Maria. Casa de alvenaria: diário de uma ex-favelada. Rio de Janeiro: Francisco Alves, 1961.

- Nossa irmã Carolina. In: JESUS, Carolina Maria de. Quarto de despejo: diário de uma favelada. $2^{a}$ ed. Rio de Janeiro: Francisco Alves, 1960.

LAJOLO, Marisa. Poesia no quarto de despejo, ou um ramo de rosas para Carolina. In: JESUS, Carolina Maria de. Antologia pessoal. Org. José Carlos Sebe Bom Meihy. Rev. Armando Freitas Filho. Rio de Janeiro: Editora da UFRJ, 1996.

MEIHY, José Carlos Sebe Bom. Os fios do desafio: o retrato de Carolina Maria de Jesus no tempo presente. In: SILVA, Vagner Gonçalves da (Org.). Artes do corpo: Memória afro-brasileira. São Paulo: Selo Negro, 2004.

. Subversão pelo sonho: a censura cultural nos diários de Carolina Maria de Jesus. In: CARNEIRO, Maria Luíza Tucci (Org.). Minorias silenciadas: História da Censura no Brasil. São Paulo: Edusp / Imprensa Oficial do Estado / Fapesp, 2002.

. O inventário de uma certa poetisa. In: JESUS, Carolina Maria de. Antologia Pessoal. Org. José Carlos Sebe Bom Meihy. Rev. Armando 
Freitas Filho. Rio de Janeiro: Editora da UFRJ, 1996.

.; LEVINE, Robert. Cinderela Negra: a saga de Carolina Maria de Jesus. Rio de Janeiro: Editora da UFRJ, 1994.

PERPÉTUA, Elzira Divina. Traços de Carolina Maria de Jesus: Gênese, Tradução e Recepção de Quarto de despejo. Tese de Doutorado em Literatura Comparada. Belo Horizonte: FALE-UFMG, 2000.

SOUSA, Germana Henriques Pereira de. Carolina Maria de Jesus: o estranho diário da escritora vira-lata. Vinhedo (SP): Horizonte, 2012. 